\title{
A GIS-based Novel Approach for Sustainable Sanitary Landfill Site Selection Using Integrated Fuzzy AHP and Machine Learning Algorithms
}

Mohd Mohsin ( $\square$ mohsin007olf@gmail.com )

Aligarh Muslim University Faculty of Engineering and Technology

Sk Ajim Ali

Aligarh Muslim University Faculty of Sciences https://orcid.org/0000-0001-7488-5591

Syed Kausar Shamim

Aligarh Muslim University Faculty of Sciences

Ateeque Ahmad

Aligarh Muslim University Faculty of Sciences

\section{Research Article}

Keywords: Sustainable waste management, Landfill site selection, Fuzzy AHP, Machine learning, Aligarh city

Posted Date: July 19th, 2021

DOl: https://doi.org/10.21203/rs.3.rs-641684/v1

License: (c) (i) This work is licensed under a Creative Commons Attribution 4.0 International License. Read Full License 


\title{
A GIS-based novel approach for sustainable sanitary landfill site selection using integrated fuzzy AHP and machine learning algorithms
}

\author{
Mohd Mohsin ${ }^{1}$, Sk Ajim Ali ${ }^{2}$, Syed Kausar Shamim², Ateeque Ahmad ${ }^{2}$ \\ 1 Department of Civil engineering, Zakir Husain College of Engineering, Faculty of \\ Engineering and Technology, Aligarh Muslim University, Aligarh, U.P. 202002, India \\ ${ }^{2}$ Department of Geography, Faculty of science, Aligarh Muslim University, Aligarh, U.P. \\ 202002, India
}

*Corresponding author: skajimali@myamu.ac.in

\begin{abstract}
Disposal of collected waste is the least preferable way of sustainable solid waste management. But most of the cities in developing nations prefer to use open dumping in an inappropriate and non-scientific way, causing negative impacts on the environment as well as human health. This study offers a novel approach for scientific landfill site selection and sustainable waste management in Aligarh city, India. This could be possible through relevant data collection, selection of suitable models for criterion weighting, and model validation. In order to prepare a suitable landfill site selection map, a GIS-based ensemble FAHP-SVM and FAHP-RF model was implemented. Considering the previous studies and the characteristics and the study area, a total of eighteen thematic layers (decision criteria) were selected. The result reveals that land value, nearness to residential roads, nearness to hospitals and clinics, distance from waste bins, and NDBI having a fuzzy weight of $>0.10$, indicates significant factors; whereas land elevation, land slope, surface temperature, soil moisture index, NDVI and urban classification having a fuzzy weight of 0 , indicates these criteria have no importance for the present study. The result further reveals that FAHP-RF with an AUC value of 0.9182 is the more accurate model in comparison to FAHP-SVM. According to the final result of weight-based overlay, a total of seven potential landfill sites were identified,
\end{abstract}


out of which three sites were determined as most suitable by considering current land cover, environmental and economic concerns, and public opinions. This study proposed a zonal division model based on the location of suitable landfill sites for sustainable waste management in the study area. The findings of this study may provide a guideline to the decision-makers and planners for optimal landfill site selection in other cities of developing countries.

Keywords: Sustainable waste management; Landfill site selection; Fuzzy AHP, Machine learning; Aligarh city

\section{Introduction}

Solid wastes are unwanted trash materials that very common with everyday life and generated by human activities from diversified sources including households, streets, markets, industrial areas, and agricultural processing (Ali 2016; Ali and Ahmad 2020). The generation of solid waste particularly in urban areas is increasing day after day, resulting in environmental degradation and contamination. The problems of solid waste generation and its management are serious issues in developing countries, like India. Due to the increased population and expansion of urban regions, the areas required for solid waste disposal also increases parallelly, resulting in a lack of available spaces and basic infrastructural amenities for solid waste disposal (Hannan et al. 2015).

Proper solid waste management (SWM) is not an easy task for planners and city authorities, especially in urban cities because the systems of solid waste management involve waste collection, transport, and disposal by considering social, environmental, and economic aspects (Ali and Ahmad 2020; Ali et al. 2021a). The hierarchical structure of sustainable SWM includes waste waste minimization, refuse, reuse, recycling, resouce recovery, and disposal in scientific sanitary landfill sites (Hazra and Goel 2009; Sk et al. 2020). 
Considering sustainable waste management, disposal is the least preferable option, whereas refuse, reuse, and recycling (3Rs concept) is the best preferable option for solid waste management (Gbanie et al. 2012; Rahman et al. 2008). Unscientific management of solid waste has direct negative impacts on the environment as well as human health (Porta et al. 2009), due to which the risk of contamination and adverse health impacts are being increased. Most of the initiatives taken for waste reduction, source segregation, and waste recycling are still not practiced in maximum cities of India (Agarwal et al. 2015; Kumar et al. 2017; Swati et al. 2018). So, the problems relating to the handling and safe disposal of waste in unscientific landfill sites are found (Ejaz et al. 2010; Ferronato and Torretta 2019).

Disposal and open dumping of unsegregated waste has a serious threat to urban areas because wastes are not dumped in suitable places to avoid all kinds of environmental problems (Abdel-Shafy and Mansour 2018; Ejaz et al. 2010; Naveen and Sivapullaiah 2020; Lu et al. 2013; Misra and Pandey 2005). However, most of the disposable sites are seen on the outskirt of the urban cities, where there are waterbodies, crops fields, park, settlements, roads, drainage, etc., these are the suitable sites for the incubation and proliferation of mosquitoes and flies (Ebistu, and Minale 2013; Ndukwe et al. 2019; Osho 2016). Inappropriate dumping of waste can be manifested by contamination of ground and surface water through leachate, soil contamination, air pollution by burning of solid waste, spreading of diseases by various vectors like insects, flies, etc. and release of methane by anaerobic decomposition (Ali and Ahmad 2019c; Ikpe et al. 2020; Moghaddas and Namaghi 2009; Tchobanoglous 2009; Starovoytova 2018). Solid waste in discriminately thrown resulted in aesthetic problems, nuisance through emitting foul smell. Therefore, suitable sites are the need of ours for a better and healthy environment. Suitable site selection for landfilling is an essential issue in fastgrowing cities of developing countries like Aligarh. Because of the complexity of SWM systems, appropriate landfill site selection is required by considering of multiple alternative 
criteria. Based on the chracteristics of the study area, different geographical factors like waterbodies, slope, elevation, surface temperature, the moisture content in the air, land use land cover, infrastructural, and accessibility of transportation systems have been taken into consideration (Ali et al. 2021a). Geospatial technology along with statistical modeling is a very significant modern scientific technique used for the identification of suitable sites wherein many factors can be integrated into one system.

Currently, there are numerous approaches and methodologies that have been applied in previous studies for suitable landfill site selection including quantitative techniques, semiquantitative techniques, statistical modeling, investigative processes, several MCDM methods, and other techniques combined with geographic information system (Ali and Ahmad 2020; Ali et al. 2021a; Djokanović et al. 2016; Eskandari et al. 2015; Torabi-Kaveh et al. 2016; Stemn and Kumi-Boateng 2019; Yildirim et al. 2018; Yousefi et al. 2018). GIS is a digital database management system that effectively evaluates and displays spatial results according to the study application (Shahabi et al. 2014; Tsai et al. 2008). GIS coupled with MCDM techniques has been widely used in suitable site selection process (Esfahani and Nik 2016; Mat et al. 2017; Moghaddam et al. 2020; Vasiljevic et al. 2012; Zarin et al. 2021). The fuzzy analytic hierarchy process has also been applied by many scholars (Beskese et al. 2015; Khademalhoseiny et al. 2017; Mallick 2021; Yalcinkaya, and Kirtiloglu 2021). But less or more all the applied techniques are similar. It would be more interesting if new integrated techniques are applied in this field of study. Therefore, the present study applied the FAHP ensemble with machine learning algorithms for identifying suitable landfill sites in an Indian urban city, Aligarh. Machine learning techniques provide more accurate result because it uses computational algorithms along with statistical models to develop a new model (Luo 2016; Meyer et al. 2019; Pourghasemi et al. 2020; Tai et al. 2019; Webb et al. 2001). More clearly, in machine learning the computer systems are learned to perform what humans do naturally, 
i.e. machines are learned from examples and experience (Alpaydin 2020). Thus, as far as the quality of examples is high, the accuracy of the result also increases.

The applications of machine learning in different fields have been found (Ali et al. 2020; Ali et al. 2021b; González-Camacho et al. 2018; Hong et al. 2020; Sarkar et al. 2019; Triantafyllidis and Tsanas, 2019; Uddin et al. 2019). More recently some studies on-site suitability have used machine learning (Al-Ruzouq et al. 2019; Chen et al. 2019; Petrov and Wessling 2015; Taghizadeh-Mehrjardi et al. 2020; Yang et al. 2015), such as a recent study on Sharjah has been carried out for dam site suitability mapping using the analytic hierarchy process and machine learning models (Al-Ruzouq et al. 2019). But the application of machine learning in landfill site suitability is very new. Thus, the fuzzy analytic hierarchy process ensemble with two machine learning techniques including support vector machine (SVM) and random forest (RF) was used in the present study.

In this paper, several issues of solid waste management in Aligarh city were emphasized first to set the objective. Aligarh city is a small-sized urban area that comes under the smart city plan of Govt. of India. Currently, Aligarh city with an area of $65.55 \mathrm{Km}^{2}$, having 80 electoral wards and 874,408 population, generating 450 tonnes of solid waste daily. Out of total solid waste generated, approximately $85 \%$ are collected and disposed of in an open landfill site, covering an area of only about 10 acres. The authority was also set up a sanitary landfill site in 2009 beside the open landfill site, but presently it is not functioned due to insufficient space (Fig. 1a). The systems of the waste collection are not effective and do not cover $100 \%$ door-to-door collection, resulting in an enormous flux of waste at the roadside, drains and residential areas (Fig. $1 b$ and $c$ ). Although the waste collection vehicles are well designed, their capacity is not enough to collect all generated waste from a specific ward (Fig. $1 d$ and e). The number of movable compacter vehicles and waste compost plants is also not sufficient. Looking towards all issues relating to solid waste generation and management in 
the area under consideration, a local meeting and interview were carried out with the administrative bodies responsible for waste management during December 2019 (Fig. 1f), and it was felt that there need to construct new sanitary landfill sites by covering the whole city for sustainable solid waste management.

The main objective of this study was to identify suitable sanitary landfill sites for scientific solid waste disposal, sustainable environment, and healthy living. The site selection criteria were retrieved based on existing literature, landfill siting guidelines, and expert judgment. The methodological principles adopted for the present analysis are based on GIS tools, fuzzy analytic hierarchy process (FAHP), machine learning models, and GPS locations verifying suitable and not suitable for landfill candidate sites. The finding of the present study will serve the purpose of Aligarh city to maintain a neat and clean urban environment and healthy living.

\section{Case study area (Aligarh city)}

Aligarh is a famous city in the north-western part of an Indian state Uttar Pradesh and acts as an administrative headquarters of Aligarh district. Geographically, the city is located between $27^{\circ} 88^{\prime} \mathrm{N}$ latitude and $78^{\circ} 08^{\prime} \mathrm{E}$ longitude (Fig. 2). The city has an average elevation of $178 \mathrm{~m}$. The Aligarh city lays approximately $140 \mathrm{Km}$ south-west and $305 \mathrm{~km}$ north-west of the Capital city, New Delhi and Kanpur, respectively, and is well connected through road and rail. The GT road passes through the city via NH-91. The monsoon-influenced subtropical humid climate is seen here. The average temperature ranges between $28^{\circ} \mathrm{C}$ and $38^{\circ} \mathrm{C}$ and an average rainfall of $227 \mathrm{~mm}$. The city is famous for its lock industry and numerous agricultural processing and manufacturing industries.

According to the last census (2011), Aligarh is a resident of approximately 147363 households. The city has 874,408 population, out of which 461,772 males and 412,636 
females with a $59.15 \%$ literacy rate. With increasing population and urbanization many environmental issues such as water pollution, water shortage, flooding, urban outdoor and indoor air pollution, improper disposal of solid waste, etc. are raising here. As the main objective of the present study is to select suitable locations for sanitary landfill sites, so it is very important to focus on waste management status and related issues in the study area. Currently, solid waste-related problems have become severe due to a gigantic quantity of solid waste generation and unsystematic management. As per the latest estimation (2021), the city has been generating about 450 tonnes of solid waste per day, an average of $0.49 \mathrm{Kg}$ per capita per day. Many issues are found relating to solid waste management systems; for example segregation of waste at sources have not been practiced throughout the city, the effective collection has not been seen, more than $85 \%$ of collected wastes are disposed of openly at the open landfill site, and there is no sanitary landfill site in the city (Khalil and Khan, 2009; Priyadarshi and Jain 2018). So, the current systems of solid waste management may cause many environmental problems and hazardous threats to inhabitants. A previous study also raised the issue and suggested a sanitary landfill in the study area (Singh et al. 2014). Therefore, there is an urgent necessity to design sanitary landfills in the city in order to sustain the management of solid waste.

\section{Materials and methods}

Fig. 3 shows materials and methods used to identify suitable landfill sites for sustainable waste management in the study area. Initially required raw data were collected to develop the thematic layers (evaluation criteria for suitable landfill site selection), and for this proper imageries and historical spatial data are required. Furthermore, a micro-level field survey is also essential to know the existing conditions of waste management, main issues relating to the present landfill site, availability of lands, and relevance of landfill site selection. Thus, different ground formations were also collected through field surveys during 2019-2020. 
Secondly, the collected raw data were processed and thematic layers were prepared. Eighteen thematic layers were developed for the present study, these are land elevation, slope, land surface temperature, soil moisture index, land use and land cover, normalized difference built-up index, normalized difference vegetation index, urban concentration, nearness to surface waterbodies, nearness to drains, nearness to a railway line, nearness to the national highway, nearness to the state highway, nearness to residential roads, nearness to hospital and clinic, nearness to park, distance from waste bins, and land value, which are grouped into five categories such as topographic and climatic criteria, land criteria, hydrological criteria, criteria related to accessibility, and criteria related to infrastructure and economy. Multiple statistical measures and spatial algorithms were applied to develop these thematic layers.

Thirdly, each thematic layer was processed for modeling and mapping suitable landfill site selection. This includes clip, multiple ring buffer, interpolation, image analysis, and raster calculation. After the primary processing, each thematic layer was further normalized by reclassifying into equal classes, i.e. five classes. Finally, a novel approach has been applied to determine the weight of each thematic layer, i.e. fuzzy analytic hierarchy process (FAHP) and machine learning algorithms (support vector machine and random forest). FAHP depends on expert's views, whereas machine learning (ML) depends on ground data which can define the suitable location for landfill sites. The integrated weight of these two techniques was applied to all thematic layers to build a new layer, called a sanitary landfill site suitability map (LSSM) using the following equation (Eq. 1).

$$
L S S M=\sum_{i \in j} W_{F A H P} \times W_{M L}
$$

where $i$ is the element of the thematic layer, $j$ is the set of all thematic layers, $W$ is the weight assigned to each thematic layer using FAHP and ML algorithms.

\subsection{Data sources}


Different datasets such as digital elevation model (DEM), satellite imageries, shapefile, and GPS coordinates were collected from different sources to prepare a GIS database. The details of thematic layers and their sources are summarized in the following table (Table 1). Satellite imageries such as DEM were collected from NASA web portal (https://earthdata.nasa.gov/), Landsat 8 from USGS earth explorer portal (https://earthexplorer.usgs.gov), and Sentinel (L2A) from Sentinel Hub EO browser (https://www.sentinelhub.com/explore/eobrowser), and specific bands were taken for specific use. Together with satellite imageries, spatial data on accessibility and infrastructure such as the location of waterbodies, drains, railway lines, national highway, state highway, residential roads, hospital and clinic, park, and waste bins were collected from Google earth and field survey based GPS pointing. Additionally, an interview survey was carried out with the executive officers, landfill site office, Aligarh Nagar Nigam, and important information was collected regarding the present issues of the existing landfill site and the relevance of new landfill site for sustainable waste management in the city (Fig. If).

\subsection{Data used and evaluation factors}

The accuracy of site suitability analysis is largely depended on the nature of data used and evaluation factors by considering environmental as well as economic factors of the study area in order to lessen the negative impacts on environmental components like water, air, and soil (Ali and Ahmad 2020; Gbanie et al. 2013). It is important to note that the evaluation factors for suitable landfill site selection differ and the same criteria get a diverse rating with changing geographical settings (Ali et al. 2021a). The selection of evaluation criteria in previous studies found at the global scale has been shown in Table 2. The evaluation criteria in ths study were selected by considering environmental components and public health safety because disposal of waste materials at unsuitable places may cause degradation of 
surrounding environmental components (Ali and Ahmad 2020; Ali et al. 2021a; Gorsevski et al. 2012, Sk et al. 2020).

Based on the aforementioned literature shown in Table 2 and guidelines of CPHEEO as shown in Table 3 on landfill site selection, eighteen landfill evaluation criteria/thematic layers were selected for the present study. In order to reduce the complexity in the calculation, these eighteen thematic layers were grouped into five broad categories. The details of criteria selection and modeling approaches have been shown in Fig. 3. The figure illustrates that the present study was carried out in four stages. In the first stage, relevant thematic layers were considered. The second stage reveals a modeling approach, i.e. a hierarchical decision-making procedure using fuzzy analytic hierarchy process was built to weight each thematic layer and combined the weight with machine learning models to prepare a suitable sanitary landfill site map. In the third stage, the models were validated and the best sites were determined in the fourth stage. The following paragraphs discuss the reasons behind the selection of eighteen landfill evaluation criteria/thematic layers.

\subsubsection{Topographic and climatic criteria}

Climate and local topography are very crucial which would be considered for assessing suitable sanitary landfill site (Ali and Ahmad 2020; Yesilnacar and Cetin 2008). Although the area under consideration is a small area covering $65.55 \mathrm{Km}^{2}$, thus, not too much areal variation has been found in terms of topography and climate. But these were considered looking towards their importance in studying landfill site suitability (Ali and Ahmad 2020; Ali et al. 2021a; Wang et al. 2009; Nas et al. 2010; Sk et al. 2020; Yesilnacar and Cetin 2005). Thus, two topographical criteria (land elevation and slope) and two climatic criteria (land surface temperature and soil moisture index) were selected in this study. 
Land elevation and slope were taken for selecting suitable landfill sites. Elevation and slope are inversely correlated with landfill site suitability score, i.e. higher elevation and degree of slope define lower suitability for landfill site (Ali and Ahmad 2020). A previous study showed that a gentle slope is more suitable and a steeper slope is not suitable for selecting landfill sites because the leachate infiltration and contamination rate is higher in a steeper slope (Ebistu and Minale 2013). Thus, an area with a slope $<10$ degrees is more suitable, whereas an area with a slope $>20$ degrees could not be considered for a sanitary landfill site (Ali and Ahmad 2020; Nas et al. 2010). On the other hand, the construction of landfills at higher elevated regions is unsuitable because of greater excavation costs than flat regions (Wang et al. 2009). So, from the economic point of view, higher elevation and slope areas should be evaded (Sk et al. 2020). The elevation of the study area ranges 160-228m and slope 0.07-29.64 degree; moderate elevation (188-190m) and lower slope (0.0774-2.0482 degree) were considered as more suitable for sanitary landfill site (Fig. $4 a$ and $4 b$ ).

The land surface temperature (LST) was considered in this study because of recognizing the areal differentiation of temperature. Previous studies showed that areas with less temperature are more suitable for sanitary landfill sites due to less exothermic reactions and landfill fires (Moqbel et al. 2010; Powell et al. 2016). Landfill fire always has negative impacts on ambient air quality (Weichenthal et al. 2015). Thus, before going to select a suitable place, it is very essential to analyze the temperature characteristics of the area. In the present study, the band-10 of Landsat 8 TIRS data and the radiative transfer equation-based method (RTE) was utilized to compute the LST as it offered more accuracy than band 11 and other methods such as split-window algorithms and mono window algorithms (Ali and Ahmad 2018; Ali and Ahmad 2019a; Ali and Ahmad 2019b; Ali and Ahmad 2020). Similar to previous studies, areas surrounding lower temperature were considered as more suitable for a landfill site than higher temperature areas (Fig. 4c). 
Consequently, soil moisture index (SMI) was also selected as a climatic factor for landfill site selection because SMI illustrates the areal differentiation of moisture content in the land surface (Ali and Ahmad 2020). SMI is also related to land surface temperature and vegetation index (Parida et al., 2008; Wang and Qu, 2009). In the present study, SMI was calculated using Landsat 8 OLI \& TIRS data. The soil moisture index can be expressed by the following equation (Eq. 2):

$$
S M I=\frac{M A X_{L S T}-L S T}{M A X_{L S T}-M I N_{L S T}}
$$

where $M A X_{L S T}$ and $M I N_{L S T}$ are the maximum and minimum surface temperatures. $M A X_{L S T}$ and $M I N_{L S T}$ were calculated by using the following equations (Eqs. $3 \& 4$ )

$$
\begin{aligned}
& M A X_{L S T}=x_{1} * N D V I+y_{1} \\
& M_{I N} N_{L S T}=x_{2} * N D V I+y_{2}
\end{aligned}
$$

where $x_{1}$ and $x_{2}$ are the highest and lowest value of normalized difference vegetation index (NDVI), $y_{1}$ and $y_{2}$ are the highest and lowest land surface temperatures, respectively.

Areas with a higher value of SMI were considered as less suitable for a sanitary landfill site because it refers to a surface with a higher value of moisture content and, whereas the lower value of SMI refers to low moisture content in land and more suitable for siting sanitary landfill (Fig. 4d).

\subsubsection{Land Criteria}

Land features are the important factors for considering suitable sites for landfills. Land features are important because for selecting any place under the suitable category of the landfill site, it must be assessed if the lands are covered by specific types of activities where the landfill process could not be carried out. In order to assess the land features, four criteria including LULC, NDBI, NDVI, and urban concentration were selected which are relevant for the study area. 
Land use and land cover is an important tool for showing areas under various land cover. It also offers micro-level classification of land use that helps in accepting and rejecting any areas based on suitability and unsuitability, respectively. For example, densely populated and residential areas, near waterbodies, close to roads, and high land-priced areas are unsuitable for landfill sites due to having environmental contamination and public health issues (Gorsevski et al., 2012; Guler and Yomralıoglu, 2017). Sentinel-2A imageries were used and Iso-cluster supervised classification was executed for land use land cover mapping. The result shows that most of the areas fall under the densely built-up category, the proportion of waterbodies and vegetation cover areas are very less. Sessional agricultural lands and open space are very scarce throughout the study area (Fig. 4e). Thus, it is very crucial to find more suitable lands here based on land availability.

Normalized difference built-up index (NDBI) is a satellite image-based computation for estimating urban built-up area and its spatial distribution. It also offers a timely and synoptic view of urban land cover. In the present study, an NDBI map was generated using the Landsat-8 OLI dataset. For the same, shortwave-infrared (SWIR) and near-infrared (NIR) bands were taken and the following equation was used (Eq. 5):

$$
N D B I=\frac{B_{S W I R}-B_{N I R}}{B_{S W I R}+B_{N I R}}
$$

where $B_{S W I R}$ and $B_{N I R}$ are the short-wave infrared (Band 7 of Landsat-8) and near-infrared band (Band 5 of Landsat-8), respectively.

The calculated value of NDBI in this analysis ranges from -0.5213 to +0.2013 . A higher value of NDBI indicates a high concentration of built-up area and should not be considered as a suitable site for a sanitary landfill (Ali and Ahmad 2020); whereas the lower value indicates less concentration of urban built-up area which may more suitable for landfill siting (Fig. 4f). Along with NDBI, the normalized difference vegetation index (NDVI) was also taken in this study because this measure estimates the density of greenness of the land surface and it is a 
very important factor while considering any place for a suitable landfill site (Mallick 2021). Similar to NDBI, the Landsat-8 OLI dataset were used to calculate the NDVI using the following equation (Eq. 6)

$$
N D B I=\frac{B_{N I R}-B_{R E D}}{B_{N I R}+B_{R E D}}
$$

where $B_{N I R}$ is the near-infrared band and $B_{R E D}$ is the red band of Landsat 8 .

The value of NDVI ranges between +1.0 and -1.0 . A lower value ( 0.1 and below) represents barren land, open space, and rocky areas, a moderate value ( 0.2 to 0.3$)$ corresponds to grassland and shrub, whereas a higher value (0.6 to 0.8$)$ indicates broad leaf rain forest. From the environmental point of view, areas with a moderate value of NDVI could be considered suitable landfill sites, while the areas with a lower value of NDVI should be avoided for siting landfill sites (Fig. $4 g$ ).

Furthermore, imagery for showing urban concentration was retrieved from the Sentinel Hub EO browser. It is highly applicable for showing the urban expansion at a local scale (Núñez et al. 2019). Urban concentration map is the utmost visible result of socio-economic and environmental forces on urban development (Núñez et al. 2019). Thus, it is an important source of city evaluation and future urban planning (Besussi et al. 2010). As proper waste management and landfill site selection is itself a part of urban planning, thus it is crucial to include this criterion for assessing the land features. Fig. $4 h$ shows the urban classification of the study area, where the less urbanized areas could be considered selecting a suitable site for sanitary landfills.

\subsubsection{Hydrological criteria}

AS per the guidelines of the CPHEEO, shown in Table 3 specific distances should be maintained for selecting landfill sites in order to avoid contamination on hydrological criteria. 
Previous studies followed specific distances for selecting landfill site; for example, landfill sites around $100-300 \mathrm{~m}$ from surface water bodies like ponds, lakes, rivers, canals, and wetlands are unsuitable because of the environmental contamination (Akbari et al. 2008; Ali and Ahmad 2020; Chang et al. 2008; Ebistu et al. 2013; Gorsevski et al. 2012).

Thus, looking towards the previous studies, two hydrological criteria such as nearness to surface waterbodies (NSW) and nearness to drains (NDN) were considered. The current location of surface waterbodies like ponds, lakes, and wetlands and drains were drawn in Google earth and export as a KML file to create a shapefile. The vector layer of these two criteria was imported into the GIS environment for proximate analysis and a certain distance of $200 \mathrm{~m}$ from surface waterbodies and $30 \mathrm{~m}$ from drains were considered. The areas close to surface waterbodies and drains were taken as a less suitable location for landfill sites and vice versa (Figs. $4 i$ and $4 j)$.

\subsubsection{Accessibility related criteria}

Accessibilities are the significant parameters of urban amenities that improve the quality of the communication system and help the urban population to enter or reach one place from another place. Associability-related criteria were selected in this study based on the CPHEEO's guidelines (Table 3). As per the guidelines, a certain distance should be kept from associability-related criteria such as railways, roads, metro, etc. before considering a site for landfilling, and hence, a landfill site should not be constructed nearby the criteria. Although from the economic point of view, if landfill site close to roads, the transport cost will be lower. But considering the environmental management and sustainable development goal, it is best to locate landfill sites distant from roads (Ali and Ahmad 2021; Sk et al. 2020). Previous studies also agreed with the same fact and used the best suitability score to far distance from road networks (Ali and Ahmad 2020; Bhambulkar 2011; Rafiee et al. 2011). 
Therefore the present study used four accessibility-related criteria, such as nearness to the railway line (NRL), nearness to national highway (NNH), nearness to state highway (NSH), and nearness to residential roads (NRR). Satellite images and Google earth were considered for creating vector format of these four criteria and imported in GIS environment for generating buffers. Due to the lower density of railway line, national highway, and state highway, a buffer was created from these criteria with a common interval of 200m (Figs. $4 k$, $4 l$, and $4 m$ ), whereas $50 \mathrm{~m}$ buffer was created from residential roads, because of it has higher density and distribution (Fig. 4n). Among the five alternatives of each of these criteria, a higher suitability score was given to far distance and lower to a closer distance for sanitary landfill sites.

\subsubsection{Criteria related to infrastructure and economy}

The term infrastructure is relating to services in a city. Hospitals, health clinics markets, parks, etc. are included in infrastructural facilities. For landfill site selection, these parameters should be considered and specific distance should be maintained in order to avoid the environmental and public health risk (Ali and Ahmad 2020). Along with economic factors also important for landfill site selection, because far distance from secondary waste collection points would increase the transport costs, landfill site at high priced lands needs more financial allowance, etc. Thus, looking towards both the infrastructural and economic conditions of the study, four relevant criteria were selected. These are nearness to the hospital and clinic (NHC), nearness to park (NPK), distance from waste bins (DWB), and land value (LV). Landfill sites should not be located near hospitals, clinics, and parks because improper waste disposal at landfill sites may cause pollution to the environment and degrade the aesthetic beauty of the surroundings. So, a common buffer with $100 \mathrm{~m}$ intervals was created along with the hospitals, clinics, and parks and a higher suitability score has been given to the area far away from these features to define a suitable site for landfilling (Figs. $4 o$ and $4 p$ ). 
Waste bins are the secondary waste collection points in the study area. So, their location has been collected from the smart city plan of Aligarh Nagar Nigam and a shapefile was created to proximate analysis with a common interval of 500m (Fig. $4 q$ ). Generally, close distance from these secondary collection points would be more profitable due to less transport cost. But it very difficult to consider landfill site closure to each waste bin because there are more than 150 locations of waste bins. So, a suitable landfill site near the locations of a maximum number of bins was considered.

Land value is a key factor that influences the location of a suitable landfill site because a higher value of land increases the construction cost (Ali and Ahmad 2021; Sk et al. 2020). For knowing the actual land value of different places of the study area, a GPS-based field survey was carried out to collect the $\mathrm{x}$ and $\mathrm{y}$ coordinates and spatial mapping was prepared using IDW interpolation (Fig. 4r). The spatial result showed that the land value of the study area ranges from Rs. 915.59 to $3,935.73$ per square foot ( 1 square foot $=0.09290$ square meter). Based on the result, a suitable sanitary landfill site could be considered at lower price areas because financial support is a matter for the study area. So, outside the city center, where the land price is low was considered as suitable for sanitary landfill site.

From the above discussion about the eighteen landfill evaluation criteria, the fuzzy score was assigned to each of the alternatives of all criteria, because the present study used fuzzy analytic hierarchy process for initial weighting the selected criteria. Table 4 shows the details of fuzzy scoring to each selected criteria considered in this study.

\subsection{Fuzzy analytic hierarchy process (FAHP)}

Fuzzy set theory was introduced by Lotfi Zadeh in 1965, which is a mathematical tool used to deal with uncertainty in decision-making process (Zadeh, 1965) and has been continuously applied in diversified field of studies including engineering, medicine, management 
meteorology, computer science, and expert decision systems (Leondes, 1998). Fuzzy offers a simple way to define crisp numbers and draw conclusions from imprecise data (Balezentiene et al. 2013). The application FAHP became wide when AHP seems unsatisfactory due to the increasing complexity of multi-criteria problems (Taha and Rostam, 2012). FAHP is also one of the outstanding and widely use multi-criteria decision making (MCDM) approaches and helps experts find out the best suits their goal and their understanding of the problem (Torfi et al., 2010). This is the main reason to choose FAHP in this study. This is a robust MCDM technique that is used for finding and understanding the problem and their solutions accordingy (Ali and Ahmad 2020).

In the present study, fuzzy extent analysis after Chang's method has been applied (Chang 1996). Applying the FAHP technique consists of four steps. The first step comprises the landfill site suitability goal; the second step consists of the pairwise comparisons of all selected criteria and calculating the fuzzy synthetic extent. The third step consists of calculating the degree of possibility. Calculating corresponding criteria weights are obtained in the final step.

For assessing the suitable sanitary landfill site, suppose, $L\left(l_{1}, l_{2} \ldots \ldots l_{n}\right)$ as relevant landfill evaluation criteria as the object set and $S\left(s_{1}, s_{2} \ldots . . s_{m}\right)$ as the suitable sites as the goal set. Employing Chang's extent analysis method, each goal $\left(\mathrm{S}_{\mathrm{i}}\right)$ is achieved by taking each object $\left(l_{i}\right)$. Thus, m extent value for each object can be achieved which is expressed in the following equation (Eq. 7):

$$
\mathrm{M}_{l i}^{1}, \mathrm{M}_{l i}^{2}, \ldots \ldots, \mathrm{M}_{l i}^{m}
$$

where $\mathrm{i}=1,2,3, \ldots \ldots ., \mathrm{n}$ and $\mathrm{M}_{l i}^{m}$ are the triangular numbers $(\mathrm{s}=1,2, \ldots \ldots, \mathrm{m})$

Based on the $\mathrm{i}^{\text {th }}$ object, the fuzzy synthetic extent value $(S i)$ can be written as $(E q .8)$ :

$$
S i=\sum_{s=1}^{n} \tilde{l} \text { is } \otimes\left[\sum_{i=1}^{n} \sum_{s=1}^{m} \tilde{l} i s\right]-1
$$


Now to obtain the $\left[\sum_{i=1}^{n} \sum_{s=1}^{m} \tilde{l} i s\right]-1$, execute the fuzzy addition function, which is expressed as (Eq. 9):

$$
\sum_{i=1}^{n} \sum_{s=1}^{m} \tilde{l} i j=\left(\sum_{s=1}^{m} l s, \sum_{s=1}^{m} m s, \sum_{s=1}^{m} u s\right) \oplus\left(\sum_{i=1}^{n} l s, \sum_{i=1}^{n} m s, \sum_{i=1}^{n} u s\right)
$$

where $l s, m s$ and $u s$ are the lower, middle, and upper limit values, respectively. By adding each value of $l, m$, and $u$, the values of the fuzzy pair-wise comparison matrix are found, which can be written as (Eq. 10):

$$
\left[\sum_{i=1}^{n} \sum_{s=1}^{m} l i s\right]-1
$$

Then the inverse of the vector was estimated using the equation below (Eq. 11):

$$
\left\{\sum_{i=1}^{n} \sum_{s=1}^{m} l i s\right\}-1=\left(\frac{1}{\sum_{i=1}^{n} u s}, \frac{1}{\sum_{i=1}^{n} m s}, \frac{1}{\sum_{i=1}^{n} l s}\right)
$$

The degree of possibility is very important for fuzzy synthetic extent because it offers the final weight. If there any mistake to compare $M_{2}$ value with other pairs in decision criteria, the whole result would be invalid. Furthermore, the value of the degree of possibility must be ranged between 0 and 1 , and in any case if the value greater than 1 , the result would also be invalid. For calculating the fuzzy weight, the degree to the possibility of $M 2=\left(\mathrm{l}_{2}, \mathrm{~m}_{2}, \mathrm{u}_{2}\right) \geq$ $\mathrm{M} 1=\left(\mathrm{l}_{1}, \mathrm{~m}_{1}, \mathrm{u}_{1}\right)$ can be defined as $(E q .12)$ :

$$
V\left(M_{2} \geq M_{2}\right)=\sup _{y \geq x}\left[\min \left(\mu_{M_{1(x)}}, \mu_{M_{2(y)}}\right)\right]=\operatorname{hgt}\left(M_{1} \cap M_{2}\right)=\mu_{M_{2\left(D_{i}\right)}}
$$

where $D_{i}$ is the highest intersection point between $\mu \mathrm{M}_{1}$ and $\mu \mathrm{M}_{2}$. The degree of possibility can also be expressed as (Eq. 13):

$$
\left\{\begin{array}{c}
1, \text { if } m_{1} \geq m_{2} \\
0, \text { if } l_{2} \geq u_{1} \\
\frac{l_{2}-u_{1}}{\left(m_{1}-u_{1}\right)-\left(m_{2}-l_{2}\right)}, \text { otherwise }
\end{array}\right.
$$


where $l, m, u$ are the lower, middle, and upper limit, respectively. For the comparison between $m_{1}$ and $m_{2}$, we need both the values of $\mathrm{V}\left(\mathrm{S}_{1} \geq \mathrm{S}_{2}\right)$ and $\mathrm{V}\left(\mathrm{S}_{2} \geq \mathrm{S}_{1}\right)$ and it will increase depending upon the selected criteria (e.g. $S_{1}, S_{2}, S_{3}, \ldots \ldots . S_{n}$ ).

Now, the degree of possibility for a convex fuzzy number to be greater than ' $\mathrm{k}$ ' convex fuzzy number was measured, as shown in the following equation (Eq. 14):

$$
\mathrm{V}\left[\left(\mathrm{S} \geq \mathrm{S}_{1}\right),\left(\mathrm{S} \geq \mathrm{S}_{2}\right), \ldots \ldots .\left(\mathrm{S} \geq \mathrm{S}_{\mathrm{k}}\right)=\min \left(\mathrm{S} \geq \mathrm{S}_{\mathrm{i}}\right), \mathrm{i}=1,2,3, \ldots \ldots \ldots \mathrm{k}\right.
$$

Using Eq. 14, the weight vector was computed and the non-fuzzy weight value was estimated based on (Eq. 15):

$$
D_{i}\left(\mathrm{~A}_{\mathrm{i}}\right)=\min \mathrm{V}\left(\mathrm{S}_{\mathrm{i}} \geq \mathrm{S}_{\mathrm{k}}\right), \mathrm{i}, \mathrm{k}=1,2,3, \ldots \ldots \mathrm{n}, \mathrm{k} \neq \mathrm{i}
$$

Finally, the weight of individual conditioning factor was estimated by employing the following equation (Eq. 16):

$$
W_{i}=\left(D_{i}\left(l_{1}\right),\left(D_{i}\left(l_{2}\right),\left(D_{i}\left(l_{3}\right),, \ldots \ldots \ldots \ldots\left(D_{i}\left(l_{n}\right)\right)^{T}\right.\right.\right.
$$

where $A_{i}(i=1,2,3, \ldots \ldots n)$ and $W^{\prime}$ is the non-fuzzy weight

\subsection{Machine learning (ML)}

\subsubsection{Support vector machine (SVM)}

SVM as a machine learning technique is generally used for supervised classification. It is based on statistical theory and offers the best result with a higher performance rate and prediction accuracy (Mohammadi et al., 2019). Support vector machine has some advantages, such as it can avoid the problem of overfitting, the capability of handling multivariate data, and non-linear independent data can be deal with this technique. In this technique, the input training data which are more close to an optimal hyperplane come into a support vector and are used for the classification of the input data (Pradhan, 2013). 
In the case of the present study, a training data $\left(c_{i}, l_{i}\right)$ with $c_{i} \in c f^{n}, l_{i} \in(1,0)$ and $i=1,2$, $3, \ldots$, n. $c$ is the input training data i.e., all landfill evaluation criteria, and $l$ are two classes 1 and 0 , implying points of a suitable site and non-suitable site locations. The main function of the support vector machine is to identify optimal hyper-plane which can separate these two classes i.e., 1 and 0 that are predefined in the training data. For linear separable data, an optimal hyper-plane can be defined as Eq. (17) (Cortes and Vapnik, 1995).

$$
l_{i}\left(s \times c_{i}+h_{p}\right) \geq 1-\varepsilon_{i}
$$

where $s$ is a support vector in the feature class that determines the direction of the hyperplane, $h_{p}$ is the offset of the hyper-plane, whereas $\varepsilon_{i}$ is the optimistic variable.

In support vector machine learning method the optimum hyper-plane is determined by resolving optimization problem based on non-linear programming which is shown in the following equation (Eq. 18) (Hoang et al., 2017):

$$
\begin{gathered}
\qquad \operatorname{Min} K_{l}(x, y)=\frac{1}{2} M^{t} v+c \frac{1}{2} \sum_{k=1}^{n} y_{k}^{2} \\
\text { Subject to } w_{k}\left\{M^{t} \varphi\left(p_{k}\right)+b_{i}\right) \geq 1-y_{k}, k=1,2,3, \ldots \ldots, n, y_{k} \geq 0
\end{gathered}
$$

Where $v$ is a vector of the hyper-plane, $M^{t}$ is the transpose matrix of $v, c$ is a penalty constant, $b_{i}$ is the bias which may arise in the model, $y_{k} \geq 0$ is the variables, $\varphi(p)$ is nonlinear data, and $K_{l}(x, y)$ is the non-linear programming.

\subsubsection{Random forest (RF)}

RF)is an efficient and intuitive method which is used for both classification and regression model (Calle and Urrea, 2010; Micheletti et al., 2014; Rebala et al., 2019). Random forest is also a supervised ML algorithm; therefore makes it easy to make out the features that affect 
regression model or classification, as well as the contribution of the variable to the decisionmaking process. Generally in RF, a decision tree (DT) is modeled on a lucid series of queries that lead serially to an answer that best fits the data used for training. A Decision Tree aims to build a model from training data by studying decision rules that predict the feature class. Random forest is a set of decision trees that outperforms a single DT in terms of prediction (Rebala et al., 2019).

Random forest determines maximum nodes in the DTs. For example, if a data with $c_{i}$ input computes its output $o_{i}$, it will determine the maximum ensemble which can be written as $(E q$. 19):

$$
c_{i}=\left(o_{i}\right)=\max \left[\sum_{j} L(i)\right]
$$

where $L(i)$ is an indicator function that can be defined as (Eq. 20) (Ali et al. 2021a).

$$
L(i)\left[\begin{array}{c}
1, i={ }^{\prime} Y E S^{\prime} \\
0, i={ }^{\prime} N O^{\prime}
\end{array}\right]
$$

where ${ }^{\prime} Y E S^{\prime}$ and ' $N O^{\prime}$ are the suitable and non-suitable landfill site location

Due to several advantages of support vector machine and random forest in classification and spatial mapping as discussed above, these two techniques were integrated with FAHP to assign a normalized weight to the evaluation criteria and generate a final landfill site suitable map.

\section{Results}

\subsection{Suitable sanitary landfill site selection}

The expansion of urban areas and increasing population is a cause of decreasing land availability for disposing of increasing daily generated solid waste in the Aligarh city, which 
is a great concern to the local bodies and administrative. The present study focused on sanitary landfill site selection in the city because the current system of landfill is open dumping which is neither scientific nor advanced designed with adequate space. So, new and backup sanitary landfill sites are required for the coming future. In this regard, primarily relevant factors that influence and connected with landfill site selection were selected looking towards environmental and socio-economic concerns and thematic layers were prepared. A total of eighteen landfill suitability criteria were considered which were grouped into five categories. Then FAHP as a multi-criteria decision-making approach ensemble with machine learning algorithms such as support vector machine (SVM) and random forest (RF) was applied for assigning weight to each of the selected decision criteria. For determining the weight of each criteria using FAHP, the fuzzy pair-wise comparison matrix was prepared in Microsoft Excel software (Table 5). Through the fuzzy comparison matrix, all the eighteen landfill site suitability predictors were compared taking into account their importance on sanitary landfill site selection according to the expert's judgment. Eq. 8 and 9 were utilized to compute the synthesis values based on the results provided by the comparison matrix.

The results obtained using the above equations were then involved in the calculation of fuzzy numbers which will be assigned to each landfill site suitability criteria. Using the fuzzy number as shown in Eq. 12, the degree of possibility was computed (Table 6). Finally, the defuzzification process allows the transformation of TFNs into the crisp weights which will be assigned to each landfill site suitability decision criteria and then multiplied with the weight of SVM and RF to derive the LSSM using ensemble model of FAHP-SVM and FAHP-RF (Table 7). The table shows that in case of the FAHP-SVM model, the land value (LV), nearness to residential roads (NRR), nearness to hospitals and clinics (NHC), and distance from waste bins (DWB) have the highest suitability weight such as $0.3202,0.1253$, 0.1084 and 0.1031 , respectively. Whereas the result of the FAHP-RF model shows that land 
value (LV), nearness to hospitals and clinics (NHC), normalized difference built-up index (NDBI), and nearness to residential roads (NRR) having the highest weight of 0.2276 , 0.1420, 0.1247 and 0.1072, respectively. As per both models (FAHP-SVM and FAHP-RF), six decision criteria out of eighteen having a Wight of 0 , and thus it indicates that these criteria have no importance in sanitary landfill site selection for the present study area. These criteria are land elevation, land slope, land surface temperature, soil moisture index, normalized difference vegetation index, and urban classification, which are mainly topographic, climatic, and land criteria.

The landfill site suitability maps (LSSM) were then prepared using both FAHP-SVM and FAHP-RF models based on weighted-overlay of different thematic layers as input criteria. The aforementioned weight based on Table 7 was then used for overlay analysis to generate sanitary landfill sites suitability map that showing suitable locations of solid waste disposal sites in the study area. The final suitability map obtained from both models was classified into four suitability classes, including highly suitable, moderately suitable, low suitable, and not suitable for landfill operation (Fig. $5 a$ and $b$ ). Highly suitable classes were finally considered for selecting suitable sanitary landfill candidate sites, whereas other classes were not taken into consideration and exclude from the analysis of the next stage to determine more suitable for new sanitary landfill sites.

Both models were validated using AUC-ROC based on the GPS point location of suitable and unsuitable sites. A total of 100 locations, corresponding to 50 each for suitable and unsuitable sites were taken into consideration to extract the suitability score from LSSM and to plot the ROC curve (Fig. $6 a$ and $b$ ). The result shows that the AUC value of FAHP-RF and FAHPSVM is $0.9182(91.82 \%)$ and $0.8730(87.30 \%)$, respectively, indicating the ensemble FAHPRF is a more accurate model than FAHP-SVM. Although both models have higher accuracy 
(>85\%), based on the AUC value, the final decision regarding the best landfill site selection was determined through the FAHP-RF model.

Fig. 7 shows the final map on sanitary landfill site suitability for the study area which was determined by considering all applied models, selected decision criteria, environmental and economic consideration, and field verification. It has been divided into two categories that are suitable and not suitable for sanitary landfill sites. The result indicates that most of the suitable sites are encircled around the open space, swamp land, barren land, and seasonal agricultural fallow. The result also shows that some areas located in the North-eastern part of the city, comes under suitable landfill site, but it could not be considered because it is under the university campus (Aligarh Muslim University) and the pixels of open and vacant places of input imageries were matched with, as there are many vacant and vegetated places in the university campus. Therefore a detail of accepting or rejecting the candidate sites for the final suitable landfill site is given here (Table 8). The Table shows that it is a part of post-analysis verification and most of the sites were rejected looking towards the environmental concern and economic point of view. Only three sites could be considered for new sanitary landfills in the city, these are sites 1,5 , and 7. Site-1 is located near the current open dumpsite, whereas site-5 and 7 are located in the northern and south-eastern parts of the city, respectively.

\subsection{Sanitary landfill site for sustainable solid waste management}

The result of this assessment reveals that many landfill candidate sites were identified for landfilling in the Aligarh city using multi-criteria and machine learning models. However, during the field survey, most of those sites could not be accepted by considering current land cover, environmental concerns, economic setup, public opinions, and the authority's decision. Only three sites could be considered for sustainable solid waste management. Based on the location of these three sites, we propose a zonal division of the study area and constructing all 
of those three sanitary landfill sites at a time instead of one landfill site for the whole city (Fig. 8). If the authority accepts the proposal, the city would be benefited by the following aspects:

(i) There is no need to increase the number of employees, laborers, sweepers, waste collecting workers, and vehicles, only a need to zonal division; may be shifting duty for an individual worker in different zones in a month.

(ii) This will help in decreasing the transport cost of waste collecting and transporting vehicles because they have to cover less distance for final waste disposal.

(iii) It will help in increasing work efficiencies including door-to-door collection, segregation, storage, transportation, and final disposal.

(iv) This will also helpful for effective maintenance and sustainable solid waste management for the city.

\section{Discussion}

Aligarh Nagar Nigam (ANN) is the responsible body for SWM in Aligarh city. Due to the industrial, commercial, and educational importance of the city, daily a large quantity of solid waste has been generated and increasing day after day. But the disposal facility of such a huge amount of unsegregated waste is poor; the availability of suitable lands has also lacked because the current open dumpsite has very little place to hold more waste after 4-5 years. In this respect, this study applied a geographic information system along with FAHP and machine learning for determining the ideal location of a suitable waste landfill site in the area under consideration. Thus, primarily this study used a hierarchical model by considering topographic, climatic, infrastructural, and accessibility-related criteria to prepare input database and fit with ensemble models. Several previous studies also select less or more 
related criteria as used in this analysis for model training and determining the most suitable landfill sites throughout the world, particularly in developing countries, where solid waste disposal is a great concern (Ali and Ahmad 2020; Ali et al. 2021a; Torabi-Kaveh et al. 2016; Stemn and Kumi-Boateng 2019;).

Traditionally, the application of GIS and various multi-criteria decision making techniques such as analytic hierarchy process (AHP), fuzzy analytic hierarchy process (FAHP), analytic network process (ANP), fuzzy analytic network process (FANP), technique for order of preference by similarity to ideal solution (TOPSIS), fuzzy technique for order of preference by similarity to ideal solution (FTOPSIS), fuzzy decision matrix (FDM), aggregated indices randomization method (AIRM), and decision making trial and evaluation laboratory (DEMATEL), etc. were used in previous studies in order to decrease risk on public health and ecological unit by integrating relevant criteria to shape landfill sites in many urban cities (Ali et al. 2021a; Aragonés-Beltrán et al. 2010; Aruldoss et al. 2013; Azizi et al. 2014; Azizi Ghalaty et al., 2016; Donevska et al. 2021; Güler and Yomralığlu 2017; Isalou et al. 2013; Kharat et al. 2019; Kharat et al., 2016; Mokhtari et al. 2015; Vasiljevic et al., 2012; Yazdani et al. 2020; Zarin et al. 2021). But the content of those studies is less or more similar, although used different MCDM techniques. Indeed, the MCDM techniques are significant for landfill site selection because there needs to judge and include many factors for locating suitable landfill sites, and thus many scholars and academicians have been utilized MCDM techniques (Alkaradaghi et al. 2014; Kharat et al. 2016; Rahimi et al. 2020). So, the present study also preferred to use the fuzzy AHP ensemble with machine learning techniques to find suitable landfill sites for sustainable waste management.

The present study has been accomplished in four interconnected stages. Firstly, GIS-based thematic layers were prepared. Secondly, the weight of each thematic layer was computed by FAHP, SVM, and RF method, and an ensemble model was built using FAHP-SVM and 
FAHP-RF. Thirdly, a weight-based overlay was implemented for LSSM and model validation. Finally, in the fourth stage, ground verification was performed for determining the most suitable sites and proposing a zonal division model for sustainable solid waste management. The application of GIS, MCDM techniques, and landfill site suitability map is not new, and hundreds of studies can be found on it (Azizi Ghalaty et al., 2016; Djokanović et al. 2016; Donevska et al. 2021; Eskandari et al. 2015; Güler and Yomralığlu 2017; Kharat et al. 2019; Yildirim et al. 2018; Yazdani et al. 2020; Yousefi et al. 2018). But the application of machine learning algorithms ensemble in MCDM and zonally division model in landfill sites for sustainable waste management is very new and it is the novelty of this analysis.

The studies carried out by many scholars have only geospatial data and geostatistical modeling dependent (Alkaradaghi et al. 2019; Aragonés-Beltrán et al. 2010; Azizi Ghalaty et al. 2016; Beskese et al. 2015; Mokhtari et al. 2015; Stemn et al. 2019; Vasiljevic et al. 2012; Yousefi et al. 2018; Zarin et al. 2021). But in consideration of environmental parameters and public health issues, the GIS and MCDM-based landfill site selection is may not be an appropriate and suitable location to be considered (Ali and Ahmad 2020). So unlike these studies, the present analysis focused on a novel approach and applied ensemble MCDM and machine learning models, verification of applied models using AUC-ROC curve, ground verification, and zonally division model-based most suitable landfill sites for sustainable waste management in the study region.

Therefore, the present study has made evident of efficiencies and performance of ensemble FAHP-SVM and FAHP-RF model in sanitary landfill site selection process with the use of GIS tools which has a great ability in analyzing spatial data and providing the accurate result in a very short time. Correspondingly, this further helps in visualizing the results in 2dimentional or 3-dimentional view that makes it easy to understand the spatial information, particularly to those who have a great interest in spatial analysis. 


\section{Conclusions}

In concluding remarks, the present study aims to find out suitable sanitary landfills sites in Aligarh city. Currently, the city is suffering from inappropriate systems of solid waste management, and open dumping is one of the serious concerns. The unscientific open dumping has a serious negative impact on environmental components as well as on public health. The city generates an enormous amount of solid waste daily, but no source segregation, recycling, effective collection, storage, and proper disposal has ever been observed. Hence, the urban local bodies should pay greater attention to find out a suitable solution and operate new sanitary landfill sites, which may fulfill all the essential requirements.

In search of a proper selection process for a sustainable waste disposal site in Aligarh city, this study has adopted a simplified system of GIS-based ensemble MCDM-ML techniques. After the existing literature survey and expert's view, eighteen thematic layers have been selected for this analysis and used in these processes to determine the suitable sanitary landfill candidate sites. As per the result of the ensemble FAHP-SVM model, the land value, nearness to residential roads, nearness to hospitals and clinics, and distance from waste bins have the highest fuzzy weight such as $0.3202,0.1253,0.1084$, and 0.1031 , respectively. Whereas the result of the FAHP-RF model shows that land value, nearness to hospitals and clinics, normalized difference built-up index, and nearness to residential roads having the highest fuzzy weight of $0.2276,0.1420,0.1247$, and 0.1072 , respectively. As per both models six decision criteria such as land elevation, land slope, land surface temperature, soil moisture index, normalized difference vegetation index, and urban classification having a fuzzy weight of 0 , which indicates that these criteria have no importance in sanitary landfill site selection for the present study area. 
Based on the integrated analysis of thematic layers in a GIS environment and implementation of FAHP-SVM and FAHP-RF, seven potential landfill site areas were identified around the study area, out of which three were selected as the most suitable site for a new sanitary landfill. Identified potential landfill sites were mostly in the open and barren lands which are far away from the populated areas and city center, and thus eliminating the risk of social and environmental conflict. The future scope will include an assessment of carcinogenic and noncarcinogenic risk due to the location of landfill sites in the given suitable areas. Finally, it is recommended that awareness and training programs for solid waste handling and disposal, environmental impact assessment, and socio-economical assessment for the potential sites need to be done.

\section{Acknowledgments}

The authors are highly thankful to the authorities of Aligarh Nagar Nigam (ANN) for a healthy discussion, taking part in a face-to-face interview, and providing relevant information, maps, data, and sharing issues regarding the new landfill site selection in the study area. The authors wish to extend their gratitude to Mr. Saleheen Murtaza, GIS Expert, Nagar Nigam, Aligarh for providing the updated city boundary and other data.

Author's Contributions Mohd Mohsin and Sk Ajim Ali prepared data, developed the methodology, analyzed, and wrote the original draft regarding the sanitary landfill site selection. Syed Kausar Shamim critically reviewed the manuscript. Ateeque Ahmad read and approved the final manuscript.

Funding No fund was received from any sources 
Availability of data and materials The data that support the findings of this study are available from the corresponding author [Sk Ajim Ali, skajimali@myamu.ac.in/ skajimali.saa@gmail.com], upon reasonable request.

\section{Compliance with ethical standards}

Ethical Approval The present study ensures that objectivity and transparency are followed in this research along with acknowledged principles of ethical and professional behaviour. The present research confirms that:

Competing interests The authors declare that they have no conflict of interest.

Research involving Human Participants and/or Animals Human Participants or Animals were not engaged or involved in the present research.

Therefore, for this study, compliance with ethical standards is not applicable

Consent to Participate Not applicable.

Consent to Publish Not applicable.

\section{References}

Abdel-Shafy, H. I., \& Mansour, M. S. (2018). Solid waste issue: Sources, composition, disposal, recycling, and valorization. Egyptian journal of petroleum, 27(4), 1275-1290.

Agarwal, R., Chaudhary, M., \& Singh, J. (2015). Waste management initiatives in India for human well being. European Scientific Journal.

Akbari, V., Rajabi, M. A., Chavoshi, S. H., \& Shams, R. (2008). Landfill site selection by combining GIS and fuzzy multi criteria decision analysis, case study: Bandar Abbas, Iran. 
$\begin{array}{llll}\text { World } & \text { Applied } & \text { Sciences } & \text { Journal, }\end{array}$ https://pdfs.semanticscholar.org/13fd/89645e1532a346a9b6253302b83d6701bb4c.pdf

Ali, S. A. (2016). Status of solid waste generation and management practice in Kolkata municipal corporation, West Bengal. International Journal of Environmental Sciences, 6(6), 1173-1186. https://doi.org/10.6088/ijes.6112

Ali, S. A., \& Ahmad, A. (2018). Using analytic hierarchy process with GIS for Dengue risk mapping in Kolkata Municipal Corporation, West Bengal, India. Spatial Information Research, 26(4), 449-469.

Ali, S. A., \& Ahmad, A. (2019a). Mapping of mosquito-borne diseases in Kolkata Municipal Corporation using GIS and AHP based decision making approach. Spatial Information Research, 27(3), 351-372. https://doi.org/10.1007/s41324-019-00242-8.

Ali, S. A., \& Ahmad, A. (2019b). Spatial susceptibility analysis of vector-borne diseases in KMC using geospatial technique and MCDM approach. Modeling Earth Systems and Environment, 5(3), 1135-1159. https://doi.org/10.1007/s40808-019-00586-y.

Ali, S. A., \& Ahmad, A. (2019c). Analysis of chemical and heavy metal concentrations of leachates and impact on groundwater quality near Dhapa dumping ground, Kolkata. Asian Profile, 47(1), 19-37.

Ali, S. A., \& Ahmad, A. (2020). Suitability analysis for municipal landfill site selection using fuzzy analytic hierarchy process and geospatial technique. Environmental Earth Sciences, 79, 1-27. https://doi.org/10.1007/s12665-020-08970-Z

Ali, S. A., Parvin, F., Al-Ansari, N., Pham, Q. B., Ahmad, A., Raj, M. S., \& Anh, D. T. (2021a). Sanitary landfill site selection by integrating AHP and FTOPSIS with GIS: a case 
study of Memari Municipality, India. Environmental Science and Pollution Research, 28(6), $7528-7550$.

Ali, S. A., Parvin, F., Pham, Q. B., Vojtek, M., Vojtekova, J., Costache, R., Linh, N. T. T., Nguyen, H. Q., Ahmad, A., \& Ghorbani, M. A. (2020). GIS-based comparative assessment of flood susceptibility mapping using hybrid multi-criteria decision-making approach, naïve Bayes tree, bivariate statistics and logistic regression: A case of Topl'a basin, Slovakia. Ecological Indicators, 117, 106620.

Ali, S. A., Parvin, F., Vojteková, J., Costache, R., Linh, N. T. T., Pham, Q. B., Vojtek, M., Gigović, L., Ahmad, A. and Ghorbani, M.A. (2021b). GIS-based landslide susceptibility modeling: A comparison between fuzzy multi-criteria and machine learning algorithms. Geoscience Frontiers, 12(2), 857-876. https://doi.org/10.1016/j.gsf.2020.09.004.

Alkaradaghi, K., Ali, S. S., Al-Ansari, N., Laue, J., \& Chabuk, A. (2019). Landfill site selection using MCDM methods and GIS in the Sulaimaniyah Governorate, Iraq. Sustainability, 11(17), 4530 .

Alpaydin, E. (2020). Introduction to machine learning. MIT press.

Al-Ruzouq, R., Shanableh, A., Yilmaz, A. G., Idris, A., Mukherjee, S., Khalil, M. A., \& Gibril, M. B. A. (2019). Dam site suitability mapping and analysis using an integrated GIS and machine learning approach. Water, 11(9), 1880.

Aragonés-Beltrán, P., Pastor-Ferrando, J. P., García-García, F., \& Pascual-Agulló, A. (2010). An analytic network process approach for siting a municipal solid waste plant in the metropolitan area of Valencia (Spain). Journal of Environmental Management, 91(5), 10711086. 
Aruldoss, M., Lakshmi, T. M., \& Venkatesan, V. P. (2013). A survey on multi criteria decision making methods and its applications. American Journal of Information Systems, $1(1), 31-43$.

Azizi Ghalaty, S., Taghizadeh, A., Heydarian, P., Farazmand, S., \& Anvaripor, R. (2016). Using multi-criteria evaluation techniques of fuzzy analytic hierarchy process and fuzzy TOPSIS in locating waste sanitary landfill sites. Journal of Research and Health, 5(4), 13-24.

Azizi, A., Malekmohammadi, B., Jafari, H. R., Nasiri, H., \& Parsa, V. A. (2014). Land suitability assessment for wind power plant site selection using ANP-DEMATEL in a GIS environment: case study of Ardabil province, Iran. Environmental monitoring and assessment, 186(10), 6695-6709.

Balezentiene, L., Streimikiene, D., \& Balezentis, T. (2013). Fuzzy decision support methodology for sustainable energy crop selection. Renewable and Sustainable Energy Reviews, 17, 83-93.

Barzehkar, M., Dinan, N. M., Mazaheri, S., Tayebi, R. M., \& Brodie, G. I. (2019). Landfill site selection using GIS-based multi-criteria evaluation (case study: SaharKhiz Region located in Gilan Province in Iran). SN Applied Sciences, 1(9), 1-11.

Beskese, A., Demir, H. H., Ozcan, H. K., \& Okten, H. E. (2015). Landfill site selection using fuzzy AHP and fuzzy TOPSIS: a case study for Istanbul. Environmental Earth Sciences, 73(7), 3513-3521.

Besussi, E., Chin, N., Batty, M., \& Longley, P. (2010). The structure and form of urban settlements. In Remote sensing of urban and suburban areas (pp. 13-31). Springer, Dordrecht. 
Bhambulkar, A. V. (2011). Municipal solid waste collection routes optimized with arc GIS network analyst. International Journal of Advanced Engineering Sciences and Technologies Vol, 11, 202-207.

Calle, M. L., \& Urrea, V. (2011). Letter to the editor: stability of random forest importance measures. Briefings in bioinformatics, 12(1), 86-89. https://doi.org/10.1093/bib/bbq011.

Chamchali, M. M., \& Ghazifard, A. (2021). A comparison of fuzzy logic and TOPSIS methods for landfill site selection according to field visits, engineering geology approach and geotechnical experiments (case study: Rudbar County, Iran). Waste Management \& Research, 39(2), 325-350.

Chang, D. Y. (1996) Applications of the extent analysis method on fuzzy AHP. Eur J Oper Res 95(3): 649-655

Chang, N. B., Parvathinathan, G., \& Breeden, J. B. (2008). Combining GIS with fuzzy multicriteria decision-making for landfill siting in a fast-growing urban region. Journal of environmental management, 87(1), 139-153. http://doi.org/10.1016/j.jenvman.2007.01.011

Chen, Y., Wu, B., Chen, D., \& Qi, Y. (2019). Using machine learning to assess site suitability for afforestation with particular species. Forests, 10(9), 739.

Cortes, C., \& Vapnik, V. (1995). Support-vector networks. Machine learning, 20(3), 273-297.

CPHEEO (2016). Manual on Municipal Solid Waste Management, First Edition

Danesh, G., Monavari, S. M., Omrani, G. A., Karbasi, A., \& Farsad, F. (2019). Compilation of a model for hazardous waste disposal site selection using GIS-based multi-purpose decision-making models. Environmental monitoring and assessment, 191(2), 1-14. 
Daneshfar, M. A., \& Ardjmand, M. (2021). A new approach in the optimal site selection of landfills for drilling cuttings from petroleum and gas fields. Chemosphere, 270, 129402.

Dereli, M. A., \& Tercan, E. (2021). Comparison of GIS-based surrogate weighting methods for multi-directional landfill site selection in West Mediterranean Planning Region in Turkey. Environment, Development and Sustainability, 23(3), 3438-3457.

Djokanović, S., Abolmasov, B., \& Jevremović, D. (2016). GIS application for landfill site selection: a case study in Pančevo, Serbia. Bulletin of Engineering Geology and the Environment, 75(3), 1273-1299.

Donevska, K., Jovanovski, J., \& Gligorova, L. (2021). Comprehensive Review of the Landfill Site Selection Methodologies and Criteria. Journal of the Indian Institute of Science, 1-13.

Ebistu, T. A., \& Minale, A. S. (2013). Solid waste dumping site suitability analysis using geographic information system (GIS) and remote sensing for Bahir Dar Town, North Western Ethiopia. African Journal of Environmental Science and Technology, 7(11), 976-989. https://doi.org/10.5897/AJEST2013.1589

Ejaz, N., Akhtar, N., Hashmi, H., \& Naeem, U. A. (2010). Environmental impacts of improper solid waste management in developing countries: A case study of Rawalpindi city. The sustainable world, 142, 379-387.

Esfahani, H. K., \& Nik, M. S. A. (2016). Use of GIS-based Multi-Criteria Decision Making to Optimal Site Selection in an Illustrative Study Area in the Center of Iran. International Journal of Engineering Research, 5(4), 260-263.

Eskandari, M., Homaee, M., Mahmoodi, S., Pazira, E., \& Van Genuchten, M. T. (2015). Optimizing landfill site selection by using land classification maps. Environmental Science and Pollution Research, 22(10), 7754-7765. 
Ferronato, N., \& Torretta, V. (2019). Waste mismanagement in developing countries: A review of global issues. International journal of environmental research and public health, 16(6), 1060.

Gbanie, S. P., Tengbe, P. B., Momoh, J. S., Medo, J., \& Kabba, V. T. S. (2013). Modelling landfill location using geographic information systems (GIS) and multi-criteria decision analysis (MCDA): case study Bo, Southern Sierra Leone. Applied Geography, 36, 3-12. https://doi.org/10.1016/j.apgeog.2012.06.013

González-Camacho, J. M., Ornella, L., Pérez-Rodríguez, P., Gianola, D., Dreisigacker, S., \& Crossa, J. (2018). Applications of machine learning methods to genomic selection in breeding wheat for rust resistance. The plant genome, 11(2), 170104.

Gorsevski, P. V., Donevska, K. R., Mitrovski, C. D., \& Frizado, J. P. (2012). Integrating multi-criteria evaluation techniques with geographic information systems for landfill site selection: a case study using ordered weighted average. Waste management, 32(2), 287-296. http://doi.org/10.1016/j.wasman.2011.09.023.

Güler, D., \& Yomralığlu, T. (2017). Alternative suitable landfill site selection using analytic hierarchy process and geographic information systems: a case study in Istanbul. Environmental Earth Sciences, 76(20), 1-13. https://doi.org/10.1007/s12665-017-7039-1

Hannan, M. A., Al Mamun, M. A., Hussain, A., Basri, H., \& Begum, R. A. (2015). A review on technologies and their usage in solid waste monitoring and management systems: Issues and challenges. Waste Management, 43, 509-523.

Hazra, T., \& Goel, S. (2009). Solid waste management in Kolkata, India: Practices and challenges. Waste management, 29(1), 470-478. 
Hong, H., Liu, J., Zhu, A. X., Shahabi, H., Pham, B. T., Chen, W., Pradhan, B., \& Bui, D. T. (2017). A novel hybrid integration model using support vector machines and random subspace for weather-triggered landslide susceptibility assessment in the Wuning area (China). Environmental Earth Sciences, 76(19), 1-19.

Hong, T., Wang, Z., Luo, X., \& Zhang, W. (2020). State-of-the-art on research and applications of machine learning in the building life cycle. Energy and Buildings, 212, 109831.

Ikpe, A., Ndon, A. I. E., \& Etim, P. J. (2020). Assessment of the waste management system and its implication in Benin City metropolis, Nigeria. Journal of Applied Research on Industrial Engineering, 7(1), 79-91.

Isalou, A. A., Zamani, V., Shahmoradi, B., \& Alizadeh, H. (2013). Landfill site selection using integrated fuzzy logic and analytic network process (F-ANP). Environmental Earth Sciences, 68(6), 1745-1755.

Jiang, S., Li, Z., \& Gao, C. (2020). Study on site selection of municipal solid waste incineration plant based on swarm optimization algorithm. Waste Management \& Research, $0734242 X 20981619$.

Kazuva, E., Zhang, J., Tong, Z., Liu, X. P., Memon, S., \& Mhache, E. (2021). GIS-and MCD-based suitability assessment for optimized location of solid waste landfills in Dar es Salaam, Tanzania. Environmental Science and Pollution Research, 28(9), 11259-11278.

Khademalhoseiny, M. S., Ahmadi Nadoushan, M., \& Radnezhad, H. (2017). Site selection for landfill gas extraction plant by fuzzy analytic hierarchy process and fuzzy analytic network process in the city of Najafabad, Iran. Energy \& Environment, 28(7), 763-774. 
Khalil, N., \& Khan, M. (2009). A case of a municipal solid waste management system for a medium-sized Indian city, Aligarh. Management of Environmental Quality: An International Journal.

Kharat, M. G., Kamble, S. J., Raut, R. D., \& Kamble, S. S. (2016). Identification and evaluation of landfill site selection criteria using a hybrid Fuzzy Delphi, Fuzzy AHP and DEMATEL based approach. Modeling Earth Systems and Environment, 2(2), 1-13.

Kharat, M. G., Murthy, S., Kamble, S. J., Raut, R. D., Kamble, S. S., \& Kharat, M. G. (2019). Fuzzy multi-criteria decision analysis for environmentally conscious solid waste treatment and disposal technology selection. Technology in Society, 57, 20-29.

Kumar, S., Smith, S. R., Fowler, G., Velis, C., Kumar, S. J., Arya, S., Kumar, R., \& Cheeseman, C. (2017). Challenges and opportunities associated with waste management in India. Royal Society open science, 4(3), 160764.

Leondes, C. T. (1998). Fuzzy logic and expert systems applications. Elsevier.

Lu, J. W., Chang, N. B., \& Liao, L. (2013). Environmental informatics for solid and hazardous waste management: advances, challenges, and perspectives. Critical reviews in environmental science and technology, 43(15), 1557-1656.

Luo, G. (2016). A review of automatic selection methods for machine learning algorithms and hyper-parameter values. Network Modeling Analysis in Health Informatics and Bioinformatics, 5(1), 1-16.

Mallick, J. (2021). Municipal Solid Waste Landfill Site Selection Based on Fuzzy-AHP and Geoinformation Techniques in Asir Region Saudi Arabia. Sustainability, 13(3), 1538. 
Mat, N. A., Benjamin, A. M., \& Abdul-Rahman, S. (2017). A review on criteria and decisionmaking techniques in solving landfill site selection problems. Journal of Advanced Review on Scientific Research, 37(1), 14-32.

Meyer, H., Reudenbach, C., Wöllauer, S., \& Nauss, T. (2019). Importance of spatial predictor variable selection in machine learning applications-Moving from data reproduction to spatial prediction. Ecological Modelling, 411, 108815.

Micheletti, N., Foresti, L., Robert, S., Leuenberger, M., Pedrazzini, A., Jaboyedoff, M., \& Kanevski, M. (2014). Machine learning feature selection methods for landslide susceptibility mapping. Mathematical geosciences, 46(1), 33-57. https://doi.org/10.1007/s11004-013-9511$\underline{0}$

Misra, V., \& Pandey, S. D. (2005). Hazardous waste, impact on health and environment for development of better waste management strategies in future in India. Environment international, 31(3), 417-431.

Moghaddam, D. D., Haghizadeh, A., Tahmasebipour, N., \& Zeinivand, H. (2020). Introducing the coupled stepwise areal constraining and Mahalanobis distance: a promising MCDM-based probabilistic model for landfill site selection. Environmental Science and Pollution Research, 27(20), 24954-24966.

Moghaddas, N. H., \& Namaghi, H. H. (2011). Hazardous waste landfill site selection in Khorasan Razavi province, northeastern Iran. Arabian journal of geosciences, 4(1), 103-113.

Mohammadi, A., Shahabi, H., \& Bin Ahmad, B. (2019). Land-Cover Change Detection in a Part of Cameron Highlands, Malaysia Using ETM+ Satellite Imagery and Support Vector Machine (SVM) Algorithm. EnvironmentAsia, 12(2). 
Mokhtari, M., Hosseini, F., Babaee, A. A., \& Mirhoseini, S. A. (2015). Application of AHP and TOPSIS models for site selection of municipal solid waste landfill (Case study: Lali City). Tolooebehdasht, 14(4), 143-153.

Moqbel, S., Reinhart, D., \& Chen, R. H. (2010). Factors influencing spontaneous combustion of solid waste. Waste Management, 30(8-9), 1600-1607.

Nas, B., Cay, T., Iscan, F., \& Berktay, A. (2010). Selection of MSW landfill site for Konya, Turkey using GIS and multi-criteria evaluation. Environmental monitoring and assessment, 160(1), 491-500. https://doi.org/10.1007/s10661-008-0713-8

Naveen, B. P., \& Sivapullaiah, P. V. (2020). Solid Waste Management: Current Scenario and Challenges in Bengaluru. In Sustainable Sewage Sludge Management and Resource Efficiency. IntechOpen.

Ndukwe, V. A., Uzoegbu, M. U., Ndukwe, O. S., \& Agibe, A. N. (2019). Environmental and Health Impact of Solid Waste Disposal in Umuahia and Environs, Southeast, Nigeria. Journal of Applied Sciences and Environmental Management, 23(9), 1615-1620.

Núñez, J. M., Medina, S., Ávila, G., \& Montejano, J. (2019). High-Resolution Satellite Imagery Classification for Urban Form Detection. Satellite Information Classification and Interpretation.

Osho, S. T. (2016). An assessment of waste management facilities in Nigeria: The impact of waste disposal facilities on public health in Lagos State, Nigeria (Doctoral dissertation, Texas Southern University).

Osra, F. A., \& Kajjumba, G. W. (2020). Landfill site selection in Makkah using geographic information system and analytical hierarchy process. Waste Management \& Research, 38(3), $245-253$. 
Parida BR, Collado WB, Borah R, Hazarika MK, Samarakoon L (2008) Detecting DroughtProne Areas of Rice Agriculture Using a MODIS-Derived Soil Moisture Index, GISci Remote Sensing 45(1):109-129, https://doi.org/10.2747/1548-1603.45.1.109

Petrov, A. N., \& Wessling, J. M. (2015). Utilization of machine-learning algorithms for wind turbine site suitability modeling in Iowa, USA. Wind Energy, 18(4), 713-727.

Porta, D., Milani, S., Lazzarino, A. I., Perucci, C. A., \& Forastiere, F. (2009). Systematic review of epidemiological studies on health effects associated with management of solid waste. Environmental health, 8(1), 1-14. https://doi.org/10.1186/1476-069X-8-60

Pourghasemi, H. R., Gayen, A., Lasaponara, R., \& Tiefenbacher, J. P. (2020). Application of learning vector quantization and different machine learning techniques to assessing forest fire influence factors and spatial modelling. Environmental research, 184, 109321.

Powell, J. T., Townsend, T. G., \& Zimmerman, J. B. (2016). Estimates of solid waste disposal rates and reduction targets for landfill gas emissions. Nature Climate Change, 6(2), $162-165$.

Pradhan, B. (2013). A comparative study on the predictive ability of the decision tree, support vector machine and neuro-fuzzy models in landslide susceptibility mapping using GIS. Computers \& Geosciences, 51, 350-365. http://dx.doi.org/10.1016/j.cageo.2012.08.023

Priyadarshi, H., \& Jain, A. (2018). Municipal solid waste management study and strategy in Aligarh City, Uttar Pradesh India. Int. J. Eng. Sci. Invent.(IJESI), 7(5), 29-40.

Rafiee, R., Khorasani, N., Mahiny, A. S., Darvishsefat, A. A., Danekar, A., \& Hasan, S. E. (2011). Siting transfer stations for municipal solid waste using a spatial multi-criteria analysis. Environmental \& Engineering Geoscience, 17(2), 143-154. https://doi.org/10.2113/gseegeosci.17.2.143 
Rahimi, S., Hafezalkotob, A., Monavari, S. M., Hafezalkotob, A., \& Rahimi, R. (2020). Sustainable landfill site selection for municipal solid waste based on a hybrid decisionmaking approach: Fuzzy group BWM-MULTIMOORA-GIS. Journal of Cleaner Production, $248,119186$.

Rahman, M. M., Sultana, K. R., \& Hoque, M. A. (2008). Suitable sites for urban solid waste disposal using GIS approach in Khulna city, Bangladesh. Proc. Pakistan Acad. Sci, 45(1), 11.

Rebala, G., Ravi, A. and Churiwala, S. (2019). An Introduction to Machine Learning, Springer International Publishing, 2019.

Sarkar, S., Vinay, S., Raj, R., Maiti, J., \& Mitra, P. (2019). Application of optimized machine learning techniques for prediction of occupational accidents. Computers \& Operations Research, 106, 210-224.

Shahabi, H., Keihanfard, S., Ahmad, B. B., \& Amiri, M. J. T. (2014). Evaluating Boolean, AHP and WLC methods for the selection of waste landfill sites using GIS and satellite images. Environmental Earth Sciences, 71(9), 4221-4233.

Singh, R. P., Yadav, D., Ayub, S., \& Siddiqui, A. A. (2014). Status and Challenges in Solid Waste Management: A case study of Aligarh City. Civil Engineering and Environmental technology.

Sk, M. M., Ali, S. A., \& Ahmad, A. (2020). Optimal Sanitary Landfill Site Selection for Solid Waste Disposal in Durgapur City Using Geographic Information System and Multicriteria Evaluation Technique. KN-Journal of Cartography and Geographic Information, 70(4), 163-180. 
Starovoytova, D. (2018). Solid Waste Management (SWM) at a University Campus (Part 1/10): Comprehensive-review on legal framework and background to waste management, at a global context. Journal of Environment and Earth Science, 8(4), 2225-0948.

Stemn, E., \& Kumi-Boateng, B. (2019). Hazardous waste landfill site selection in Western Ghana: An integration of multi-criteria decision analysis and geographic information system. Waste Management \& Research, 37(7), 723-736.

Swati, T. I., Vijay, V. K., \& Ghosh, P. (2018). Scenario of landfilling in India: problems, challenges, and recommendations. Handbook of environmental materials management. Springer, Cham, 1-16.

Taghizadeh-Mehrjardi, R., Nabiollahi, K., Rasoli, L., Kerry, R., \& Scholten, T. (2020). Land suitability assessment and agricultural production sustainability using machine learning models. Agronomy, 10(4), 573.

Taha, Z., \& Rostam, S. (2012). A hybrid fuzzy AHP-PROMETHEE decision support system for machine tool selection in flexible manufacturing cell. Journal of Intelligent Manufacturing, 23(6), 2137-2149.

Tai, A. M., Albuquerque, A., Carmona, N. E., Subramanieapillai, M., Cha, D. S., Sheko, M., \& McIntyre, R. S. (2019). Machine learning and big data: Implications for disease modeling and therapeutic discovery in psychiatry. Artificial intelligence in medicine, 99, 101704.

Tchobanoglous, G. (2009). Solid waste management. Environmental engineering: environmental health and safety for municipal infrastructure, land use and planning, and industry. Wiley, New Jersey, 177-307. 
Tercan, E., Dereli, M. A., \& Tapkın, S. (2020). A GIS-based multi-criteria evaluation for MSW landfill site selection in Antalya, Burdur, Isparta planning zone in Turkey. Environmental Earth Sciences, 79, 1-17.

Torabi-Kaveh, M., Babazadeh, R., Mohammadi, S. D., \& Zaresefat, M. (2016). Landfill site selection using combination of GIS and fuzzy AHP, a case study: Iranshahr, Iran. Waste Management \& Research, 34(5), 438-448.

Torfi, F., Farahani, R. Z., \& Rezapour, S. (2010). Fuzzy AHP to determine the relative weights of evaluation criteria and Fuzzy TOPSIS to rank the alternatives. Applied Soft Computing, 10(2), 520-528.

Triantafyllidis, A. K., \& Tsanas, A. (2019). Applications of machine learning in real-life digital health interventions: review of the literature. Journal of medical Internet research, 21(4), e12286.

Tsai, C. H., Chen, C. W., Chiang, W. L., \& Lin, M. L. (2008). Application of geographic information system to the allocation of disaster shelters via fuzzy models. Engineering Computations.

Uddin, S., Khan, A., Hossain, M. E., \& Moni, M. A. (2019). Comparing different supervised machine learning algorithms for disease prediction. BMC medical informatics and decision making, 19(1), 1-16.

Vasiljevic, T. Z., Srdjevic, Z., Bajcetic, R., \& Miloradov, M. V. (2012). GIS and the analytic hierarchy process for regional landfill site selection in transitional countries: a case study from Serbia. Environmental Management, 49(2), 445. 
Wang, G., Qin, L., Li, G., \& Chen, L. (2009). Landfill site selection using spatial information technologies and AHP: a case study in Beijing, China. Journal of environmental management, 90(8), 2414-2421. https://doi.org/10.1016/j.jenvman.2008.12.008

Wang, L., \& Qu, J. J. (2009). Satellite remote sensing applications for surface soil moisture monitoring: A review. Frontiers Earth Sci China 3(2):237-247. https://doi.org/10.1007/s11707-009-0023-7

Webb, G. I., Pazzani, M. J., \& Billsus, D. (2001). Machine learning for user modeling. User modeling and user-adapted interaction, 11(1), 19-29.

Weichenthal, S., Van Rijswijk, D., Kulka, R., You, H., Van Ryswyk, K., Willey, J., et al. (2015). The impact of a landfill fire on ambient air quality in the north: A case study in Iqaluit, Canada. Environmental research, 142, 46-50.

Yalcinkaya, S., \& Kirtiloglu, O. S. (2021). Application of a geographic information systembased fuzzy analytic hierarchy process model to locate potential municipal solid waste incineration plant sites: A case study of Izmir Metropolitan Municipality. Waste Management \& Research, 39(1), 174-184.

Yang, Y., Tang, J., Luo, H., \& Law, R. (2015). Hotel location evaluation: A combination of machine learning tools and web GIS. International Journal of Hospitality Management, 47, $14-24$.

Yesilnacar, M. I., \& Cetin, H. (2005). Site selection for hazardous wastes: a case study from the GAP area, Turkey. Engineering Geology, 81(4), 371-388. https://doi.org/10.1016/j.enggeo.2005.07.012. 
Yesilnacar, M. I., \& Cetin, H. (2008). An environmental geomorphologic approach to site selection for hazardous wastes. Environmental Geology, 55(8), 1659-1671. https://doi.org/10.1007/s00254-007-1115-x

Yildirim, V., Memisoglu, T., Bediroglu, S., \& Colak, H. E. (2018). Municipal solid waste landfill site selection using Multi-Criteria Decision Making and GIS: case study of Bursa province. Journal of Environmental Engineering and Landscape Management, 26(2), 107119.

Yousefi, H., Javadzadeh, Z., Noorollahi, Y., \& Yousefi-Sahzabi, A. (2018). Landfill Site selection using a multi-criteria decision-making method: a case study of the Salafcheghan special economic zone, Iran. Sustainability, 10(4), 1107.

Zadeh LA (1965) Fuzzy sets. Inf Control 8(3):338-353

Zarin, R., Azmat, M., Naqvi, S. R., Saddique, Q., \& Ullah, S. (2021). Landfill site selection by integrating fuzzy logic, AHP, and WLC method based on multi-criteria decision analysis. Environmental Science and Pollution Research, 28(16), 19726-19741.

\section{List of tables}

Table 1 Various evaluation criteria and their sources used in the present study

\begin{tabular}{|l|l|l|}
\hline Thematic layers/evaluation criteria & Date source & Data type \\
\hline Land elevation and slope & NASA web portal & Raster \\
\hline $\begin{array}{l}\text { Land surface temperature, soil } \\
\text { moisture index, normalized difference } \\
\text { built-up index and normalized } \\
\text { difference vegetation index }\end{array}$ & Landsat 8 OLI \& TIRS & Raster \\
\hline $\begin{array}{l}\text { Land use and land cover, urban } \\
\text { concentration }\end{array}$ & Sentinel 2A & Raster \\
\hline Waterbodies & Google earth & $\begin{array}{l}\text { Vector (polygon } \\
\text { shapefile) }\end{array}$ \\
\hline Drains & Google earth & $\begin{array}{l}\text { Vector (polyline } \\
\text { shapefile) }\end{array}$ \\
\hline
\end{tabular}




\begin{tabular}{|l|l|l|}
\hline $\begin{array}{l}\text { Railways, national highway, state } \\
\text { highway and residential roads }\end{array}$ & Google earth & $\begin{array}{l}\text { Vector (polyline } \\
\text { shapefile) }\end{array}$ \\
\hline Hospital and clinic & $\begin{array}{l}\text { Municipal authority, Aligarh } \\
\text { Nagar Nigam }\end{array}$ & $\begin{array}{l}\text { Vector (point } \\
\text { shapefile) }\end{array}$ \\
\hline Parks & $\begin{array}{l}\text { Municipal authority, Aligarh } \\
\text { Nagar }\end{array}$ & $\begin{array}{l}\text { Vector (polygon } \\
\text { shapefile) }\end{array}$ \\
\hline Waste bins & $\begin{array}{l}\text { Smart city plan, Aligarh Nagar } \\
\text { Nigam }\end{array}$ & $\begin{array}{l}\text { Vector (point } \\
\text { shapefile) }\end{array}$ \\
\hline Land value & Field survey & $\begin{array}{l}\text { Vector (point } \\
\text { shapefile) }\end{array}$ \\
\hline
\end{tabular}


Table 2 Review of recent literature on landfill site suitability throughout the world

\begin{tabular}{|c|c|c|c|c|c|}
\hline $\begin{array}{l}\text { Sl. } \\
\text { No. }\end{array}$ & $\begin{array}{l}\text { References (studied } \\
\text { by) }\end{array}$ & Published year & Study area & Factors selected (thematic layers) & Methods applied \\
\hline 1 & Ali et al. & 2021 & $\begin{array}{l}\text { Memari, West } \\
\text { Bengal, India }\end{array}$ & $\begin{array}{l}\text { River \& canal, waterbodies, tube well, } \\
\text { pipeline, land elevation, land use land } \\
\text { cover, residential area, sensitive place and } \\
\text { restricted places, highway, urban metalled } \\
\text { roads, population density, and land value }\end{array}$ & $\begin{array}{l}\text { Analytical Hierarchy } \\
\text { Process (AHP) and fuzzy } \\
\text { technique for order of } \\
\text { preference by similarity to } \\
\text { ideal solution (TOPSIS) }\end{array}$ \\
\hline 4 & Barzehkar et al. & 2019 & $\begin{array}{l}\text { SaharKhiz } \\
\text { Region, Gilan } \\
\text { Province, Iran }\end{array}$ & $\begin{array}{l}\text { Slope, fault, Flooding, Groundwater depth, } \\
\text { lake, river, shoreline, protected area, } \\
\text { wetland, population centers, road, power } \\
\text { transmission line, gas pipeline, and } \\
\text { industrial areas }\end{array}$ & $\begin{array}{l}\text { Fuzzy logic and Boolean } \\
\text { logic }\end{array}$ \\
\hline 5 & Chamchali & 2021 & Rudbar County, & Temperature, city areas, environmental & TOPSIS and fuzzy logic \\
\hline
\end{tabular}




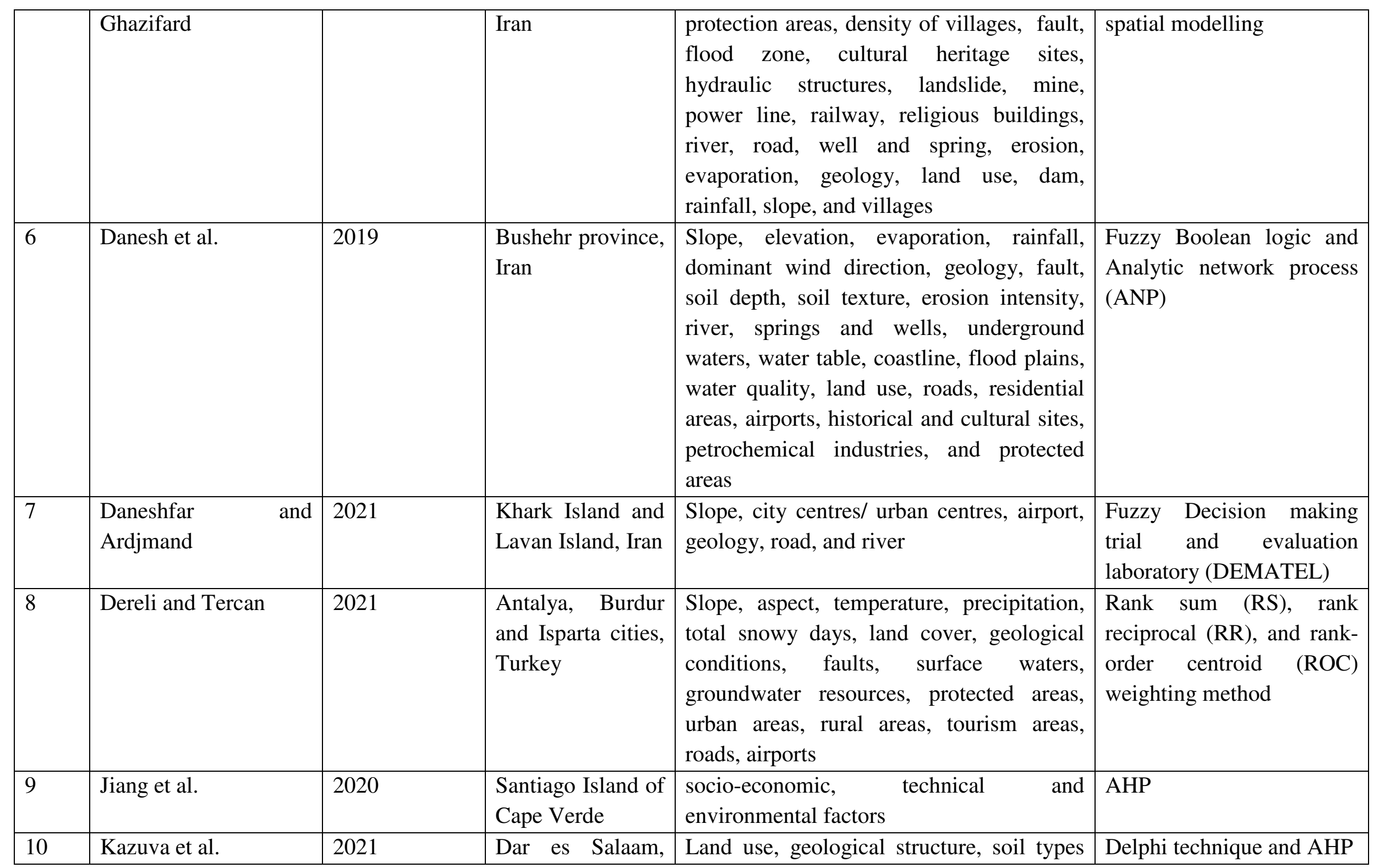




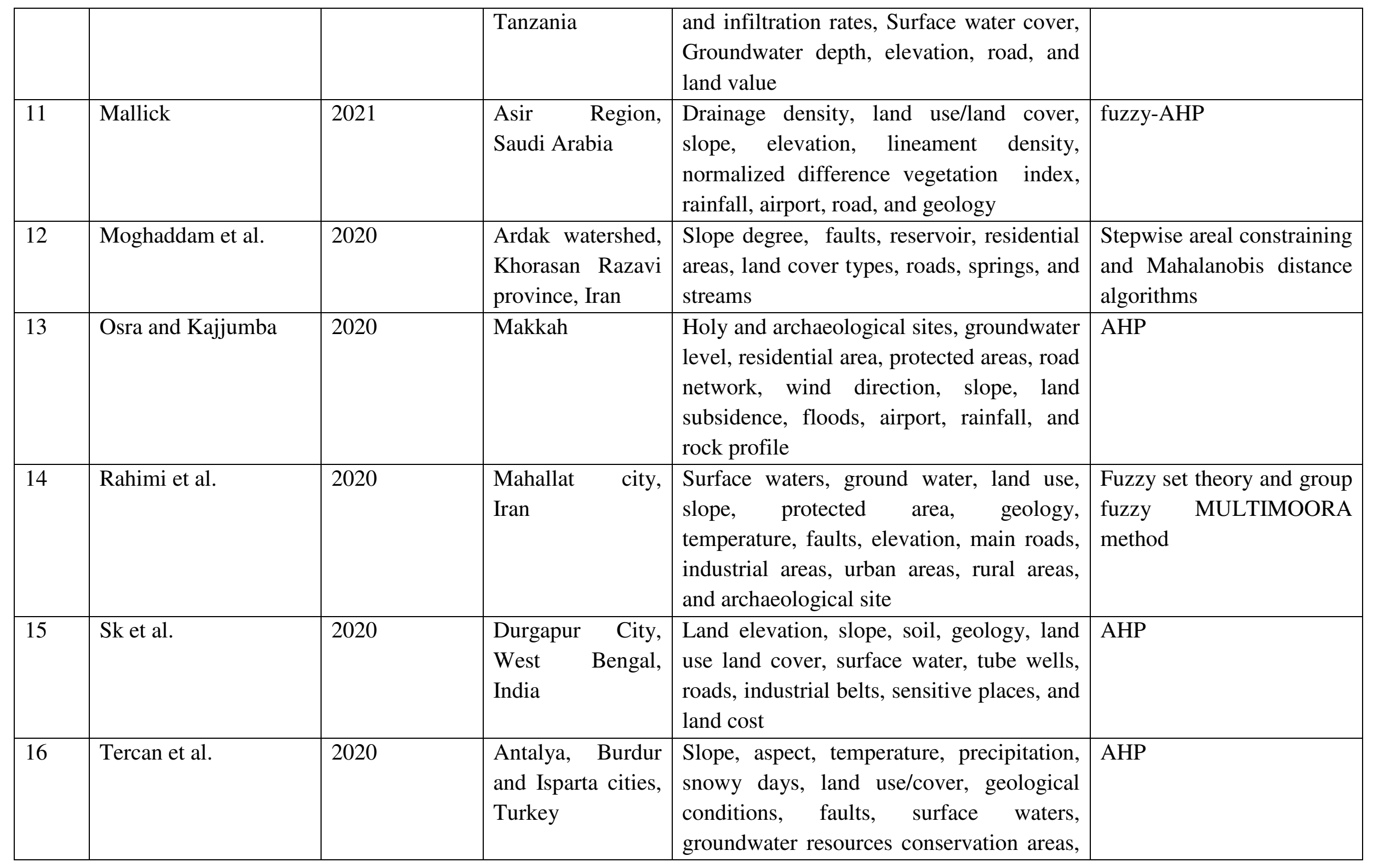




\begin{tabular}{|l|l|l|l|l|l|}
\hline & & & & $\begin{array}{l}\text { protected areas, urban residential areas, } \\
\text { rural residential areas, tourism areas, land } \\
\text { transportation network, airport }\end{array}$ \\
\hline 17 & $\begin{array}{l}\text { Yalcinkaya and } \\
\text { Kirtiloglu }\end{array}$ & 2021 & $\begin{array}{l}\text { Izmir } \\
\text { Metropolitan } \\
\text { Municipality, } \\
\text { Turkey }\end{array}$ & $\begin{array}{l}\text { Main roads, transfer stations, transformers, } \\
\text { power lines, MSW availability, elevation, } \\
\text { and slope }\end{array}$ & $\begin{array}{l}\text { Fuzzy } \\
\text { functions and AHP }\end{array}$ \\
\hline 18 & Yildirim et al. & 2018 & $\begin{array}{l}\text { Bursa province, } \\
\text { Turkey }\end{array}$ & $\begin{array}{l}\text { Waterbodies, land use, geology, soil, } \\
\text { protection zoPSIS and Cost Surface } \\
\text { protection, population, forest, residential } \\
\text { areas, road, hydrology and slope }\end{array}$ \\
\hline 19 & Yousefi et al. & 2018 & $\begin{array}{l}\text { Salafchegan } \\
\text { special economic } \\
\text { zone, Iran }\end{array}$ & $\begin{array}{l}\text { Depth of groundwater, surface and } \\
\text { groundwater, access routes, residential } \\
\text { areas, industries, power transmission lines, } \\
\text { flood-proneness, faults, slope, and gardens } \\
\text { and agricultural lands }\end{array}$ \\
\hline 20 & Zarin et al. & 2021 & $\begin{array}{l}\text { Slope, soil type, land cover, waterbodies } \\
\text { and rivers, main roads, railway lines, } \\
\text { Settlements, soil types, and population } \\
\text { Pakistan }\end{array}$ & $\begin{array}{l}\text { Fuzzy logic, AHP, and } \\
\text { WLC }\end{array}$ \\
\hline
\end{tabular}


Table 3 CPHEEO guidelines on landfill site selection criteria

\begin{tabular}{|c|c|c|}
\hline Criteria/factors & Minimum siting distance to be preferred & According to \\
\hline Rivers & $\begin{array}{l}100 \text { metres }(m) \text { away from the flood } \\
\text { plain }\end{array}$ & CPHEEO 2016 \\
\hline Pond, lakes, water bodies & $200 \mathrm{~m}$ & CPHEEO 2016 \\
\hline $\begin{array}{l}\text { Non-meandering water } \\
\text { channel (Canal, drainage, } \\
\text { etc.) }\end{array}$ & $30 \mathrm{~m}$ & CPHEEO 2016 \\
\hline $\begin{array}{l}\text { Railway line, water supply } \\
\text { wells }\end{array}$ & $500 \mathrm{~m}$ from centre line & CPHEEO 2016 \\
\hline $\begin{array}{l}\text { State highway or national } \\
\text { highway }\end{array}$ & $200 \mathrm{~m}$ from centre line & CPHEEO 2016 \\
\hline $\begin{array}{l}\text { Urban metalled roads/ } \\
\text { residential roads }\end{array}$ & Not specified & CPHEEO 2016 \\
\hline Habitation & All landfill facilities: $500 \mathrm{~m}$ & CPHEEO 2016 \\
\hline $\begin{array}{l}\text { Sensitive places (Hospital, } \\
\text { park, school, bank etc.) }\end{array}$ & Landfill site not permitted & CPHEEO 2016 \\
\hline $\begin{array}{l}\text { wetland, critical habitat } \\
\text { areas, sensitive eco-fragile } \\
\text { areas, and flood plains as } \\
\text { recorded for the last } 100 \\
\text { years }\end{array}$ & $\begin{array}{l}\text { Sanitary landfill site not permitted } \\
\text { within these identified areas }\end{array}$ & CPHEEO 2016 \\
\hline Water table (highest level) & $\begin{array}{l}\text { The bottom liner of the landfill should } \\
\text { be above } 2 \mathrm{~m} \text { from the highest water } \\
\text { table }\end{array}$ & CPHEEO 2016 \\
\hline
\end{tabular}

Note: CPHEEO is the Central Public Health and Environmental Engineering Organisation

Table 4 Fuzzy score based on expert's view and calculated synthetic extent of all criteria considered for sanitary landfill site suitability

\begin{tabular}{|l|l|l|l|}
\hline Thematic layers/criteria & Alternatives & $\begin{array}{l}\text { Fuzzy } \\
\text { score }\end{array}$ & $\begin{array}{l}\text { Fuzzy synthetic } \\
\text { extent }\end{array}$ \\
\hline Land elevation $(\mathrm{m})$ & $160-183$ & $(1,1,1)$ & \multirow{2}{*}{$(6.06,8.95,12.68)$} \\
\cline { 2 - 3 } & $184-187$ & $(2,3,4)$ & \\
\cline { 2 - 3 } & $188-190$ & $(5,6,7)$ & \\
\cline { 2 - 3 } & $191-195$ & $(3,4,5)$ & \\
\cline { 2 - 3 } & $196-228$ & $(2,3,4)$ & \\
\hline Slope (degree) & $0.07-2.04$ & $(6,7,8)$ & \multirow{2}{*}{$(4.55,5.64,7.92)$} \\
\cline { 2 - 3 } & $2.05-3.78$ & $(4,5,6)$ & \\
\cline { 2 - 3 } & $3.79-5.99$ & $(3,4,5)$ & \\
\cline { 2 - 3 } & $6.00-9.46$ & $(2,3,4)$ & \\
\cline { 2 - 3 } & $9.47-29.64$ & $(1,1,1)$ & \\
\hline Land surface temperature $\left({ }^{\circ} \mathrm{C}\right)$ & $26.32-32.19$ & $(5,6,7)$ & \multirow{2}{*}{$(8.45,12.68,18.57)$} \\
\cline { 2 - 3 } & $32.20-34.33$ & \\
\hline
\end{tabular}




\begin{tabular}{|c|c|c|c|}
\hline & $34.34-35.46$ & $(3,4,5)$ & \\
\hline & $35.47-36.76$ & $(1,2,3)$ & \\
\hline & $36.77-40.71$ & $(1,1,1)$ & \\
\hline \multirow[t]{5}{*}{ Soil moisture index } & (-)0.01 to 0.26 & $(4,5,6)$ & \multirow[t]{5}{*}{$(5.8,8.17,12.4)$} \\
\hline & $0.27-0.35$ & $(3,4,5)$ & \\
\hline & $0.36-0.43$ & $(2,3,4)$ & \\
\hline & $0.44-0.58$ & $(1,2,3)$ & \\
\hline & $0.58-1.00$ & $(1,1,1)$ & \\
\hline \multirow{4}{*}{ Land use and land cover } & Settlement & $(1,1,1)$ & \multirow{4}{*}{$(22.56,32.83,45.5)$} \\
\hline & Vegetation & $(2,3,4)$ & \\
\hline & $\begin{array}{l}\text { Open space and swamp } \\
\text { land }\end{array}$ & $(5,6,7)$ & \\
\hline & Barren land & $(6,7,8)$ & \\
\hline \multirow{5}{*}{$\begin{array}{l}\text { Normalized difference built-up } \\
\text { index }\end{array}$} & $(-) 0.52-(-) 0.28$ & $(4,5,6)$ & \multirow[t]{5}{*}{$(26.28,38.74,51.83)$} \\
\hline & $(-) 0.28--0.15$ & $(2,3,4)$ & \\
\hline & $(-) 0.15--0.08$ & $(2,3,4)$ & \\
\hline & $(-) 0.08--0.031$ & $(1,2,3)$ & \\
\hline & $(-) 0.032-0.201$ & $(1,1,1)$ & \\
\hline \multirow{5}{*}{$\begin{array}{l}\text { Normalized difference } \\
\text { vegetation index }\end{array}$} & $(-) 0.03-0.08$ & $(3,4,5)$ & \multirow[t]{5}{*}{$(13.11,18.22,24.82)$} \\
\hline & $0.09-0.13$ & $(2,3,4)$ & \\
\hline & $0.14-0.20$ & $(1,2,3)$ & \\
\hline & $0.21-0.31$ & $(1,2,3)$ & \\
\hline & $0.32-0.53$ & $(1,1,1)$ & \\
\hline \multirow[t]{5}{*}{ Urban concentration } & $0.01-0.20$ (very low) & $(3,4,5)$ & \multirow[t]{5}{*}{$(16.04,22.15,29.82)$} \\
\hline & $0.21-0.40$ (Low) & $(2,3,4)$ & \\
\hline & $0.41-0.60$ (Moderate) & $(1,2,3)$ & \\
\hline & $0.61-0.80$ (High) & $(1,2,3)$ & \\
\hline & $0.81-1.00$ (Very high) & $(1,1,1)$ & \\
\hline \multirow{5}{*}{$\begin{array}{l}\text { Nearness to surface waterbodies } \\
\text { (m) }\end{array}$} & $0-200$ & $(1,1,1)$ & \multirow[t]{5}{*}{$(17.38,25.28,34.49)$} \\
\hline & $201-400$ & $(1,2,3)$ & \\
\hline & $401-600$ & $(1,2,3)$ & \\
\hline & $601-800$ & $(3,4,5)$ & \\
\hline & $801-1000$ & $(5,6,7)$ & \\
\hline \multirow[t]{5}{*}{ Nearness to drains (m) } & $0-30$ & $(1,1,1)$ & \multirow[t]{5}{*}{$(18.45,26.36,35.57)$} \\
\hline & $31-60$ & $(1,2,3)$ & \\
\hline & $61-90$ & $(2,3,4)$ & \\
\hline & $91-120$ & $(4,5,6)$ & \\
\hline & $121-150$ & $(5,6,7)$ & \\
\hline \multirow[t]{5}{*}{ Nearness to railway line (m) } & $0-200$ & $(1,1,1)$ & \multirow[t]{5}{*}{$(21.01,30.81,41.83)$} \\
\hline & $201-400$ & $(1,2,3)$ & \\
\hline & $401-600$ & $(2,3,4)$ & \\
\hline & $601-800$ & $(3,4,5)$ & \\
\hline & $801-1000$ & $(5,6,7)$ & \\
\hline \multirow{2}{*}{$\begin{array}{l}\text { Nearness to national highway } \\
\text { (m) }\end{array}$} & $0-200$ & $(1,1,1)$ & \multirow{2}{*}{$(21.41,31.80,42.53)$} \\
\hline & $201-400$ & $(1,2,3)$ & \\
\hline
\end{tabular}




\begin{tabular}{|c|c|c|c|}
\hline & $401-600$ & $(1,2,3)$ & \\
\hline & $601-800$ & $(4,5,6)$ & \\
\hline & $801-1000$ & $(5,6,7)$ & \\
\hline \multirow[t]{5}{*}{ Nearness to state highway (m) } & $0-200$ & $(1,1,1)$ & \multirow[t]{5}{*}{$(24.81,35.49,47.16)$} \\
\hline & $201-400$ & $(1,2,3)$ & \\
\hline & $401-600$ & $(2,3,4)$ & \\
\hline & $601-800$ & $(3,4,5)$ & \\
\hline & $801-1000$ & $(5,6,7)$ & \\
\hline \multirow{5}{*}{$\begin{array}{l}\text { Nearness to residential roads } \\
\text { (m) }\end{array}$} & $0-50$ & $(1,1,1)$ & \multirow[t]{5}{*}{$(35.1,47.48,60.33)$} \\
\hline & $51-100$ & $(1,1,1)$ & \\
\hline & $101-150$ & $(2,3,4)$ & \\
\hline & $151-200$ & $(4,5,6)$ & \\
\hline & $201-250$ & $(5,6,7)$ & \\
\hline \multirow{5}{*}{$\begin{array}{l}\text { Nearness to hospital and clinic } \\
\text { (m) }\end{array}$} & $0-100$ & $(1,1,1)$ & \multirow[t]{5}{*}{$(40.75,56.33,70.5)$} \\
\hline & $101-200$ & $(1,2,3)$ & \\
\hline & $201-300$ & $(2,3,4)$ & \\
\hline & $301-400$ & $(4,5,6)$ & \\
\hline & $401-500$ & $(6,7,8)$ & \\
\hline \multirow[t]{5}{*}{ Nearness to park (m) } & $0-100$ & $(1,1,1)$ & \multirow[t]{5}{*}{$(43.74,58.03,71.75)$} \\
\hline & $101-200$ & $(1,2,3)$ & \\
\hline & $201-300$ & $(3,4,5)$ & \\
\hline & $301-400$ & $(4,5,6)$ & \\
\hline & $401-500$ & $(5,6,7)$ & \\
\hline \multirow[t]{5}{*}{ Distance from waste bins (m) } & $0-100$ & $(1,1,1)$ & \multirow[t]{5}{*}{$(41.25,57.33,73.50)$} \\
\hline & $101-200$ & $(1,2,3)$ & \\
\hline & $201-300$ & $(4,5,6)$ & \\
\hline & $301-400$ & $(3,4,5)$ & \\
\hline & $401-500$ & $(2,3,4)$ & \\
\hline \multirow[t]{5}{*}{ Land value (per square feet) } & $915-1,803$ & $(7,8,9)$ & \multirow[t]{5}{*}{$(60,77,94)$} \\
\hline & $1,804-2,277$ & $(6,7,8)$ & \\
\hline & $2,278-2,668$ & $(3,4,5)$ & \\
\hline & $2,669-3,059$ & $(2,3,4)$ & \\
\hline & $3,060-3,935$ & $(1,1,1)$ & \\
\hline
\end{tabular}


1 Table 5 Fuzzy pair-wise comparison matrix of selected criteria/thematic layers

\begin{tabular}{|c|c|c|c|c|c|c|c|c|c|c|c|c|c|c|c|c|c|c|c|}
\hline & $\mathrm{LE}$ & LS & $\begin{array}{l}\mathrm{LS} \\
\mathrm{T}\end{array}$ & $\begin{array}{l}\mathrm{S} \\
\mathrm{MI}\end{array}$ & $\begin{array}{l}\mathrm{LU} \\
\mathrm{LC}\end{array}$ & $\begin{array}{l}\mathrm{N} \\
\mathrm{D} \\
\mathrm{BI} \\
\end{array}$ & GC & $\mathrm{UC}$ & $\begin{array}{l}\text { NS } \\
\mathrm{W}\end{array}$ & $\begin{array}{l}\mathrm{ND} \\
\mathrm{N}\end{array}$ & $\begin{array}{l}\text { NR } \\
\mathrm{L}\end{array}$ & $\begin{array}{l}\mathrm{NN} \\
\mathrm{H}\end{array}$ & $\begin{array}{l}\mathrm{NS} \\
\mathrm{H}\end{array}$ & $\begin{array}{l}\text { NR } \\
\mathrm{R}\end{array}$ & $\begin{array}{l}\mathrm{NH} \\
\mathrm{C}\end{array}$ & $\begin{array}{l}\text { NP } \\
\mathrm{R}\end{array}$ & $\begin{array}{l}\mathrm{D} \\
\mathrm{W} \\
\mathrm{B} \\
\end{array}$ & LV & $\begin{array}{l}\text { fuzzy } \\
\text { syntheti } \\
\text { c extent }\end{array}$ \\
\hline $\begin{array}{l}\mathrm{L} \\
\mathrm{E}\end{array}$ & $\begin{array}{l}(1, \\
1,1 \\
)\end{array}$ & $\begin{array}{l}(1, \\
2,3 \\
)\end{array}$ & $\begin{array}{l}(.3 \\
3, . \\
5,1 \\
)\end{array}$ & $\begin{array}{l}(1, \\
2,3 \\
)\end{array}$ & $\begin{array}{l}(.2 \\
0, .2 \\
5, .3 \\
3) \\
\end{array}$ & $\begin{array}{l}(.2 \\
5, . \\
33, \\
.5)\end{array}$ & $\begin{array}{l}.2 \\
0, .2 \\
5, .3 \\
3) \\
\end{array}$ & $\begin{array}{l}(.1 \\
6, .2 \\
0, .2 \\
5) \\
\end{array}$ & $\begin{array}{l}.2 \\
0, .2 \\
5, .3 \\
3) \\
\end{array}$ & $\begin{array}{l}.2 \\
0, .2 \\
5, .3 \\
3) \\
\end{array}$ & $\begin{array}{l}(.2 \\
5, . \\
33, \\
.5)\end{array}$ & $\begin{array}{l}.2 \\
0, .2 \\
5, .3 \\
3) \\
\end{array}$ & $\begin{array}{l}(.1 \\
6, .2 \\
0, .2 \\
5) \\
\end{array}$ & $\begin{array}{l}.1 \\
6, .2 \\
0, .2 \\
5) \\
\end{array}$ & $\begin{array}{l}(.2 \\
0, .2 \\
5, .3 \\
3) \\
\end{array}$ & $\begin{array}{l}(.2 \\
5, . \\
33, \\
.5)\end{array}$ & $\begin{array}{l}.1 \\
6, .2 \\
0, .2 \\
5) \\
\end{array}$ & $\begin{array}{l}(.14 \\
, .16 \\
. .20 \\
) \\
\end{array}$ & $\begin{array}{l}6.06,8 . \\
95,12.6 \\
8\end{array}$ \\
\hline $\begin{array}{l}\mathrm{L} \\
\mathrm{S}\end{array}$ & $\begin{array}{l}(.3 \\
3, . \\
5,1 \\
)\end{array}$ & $\begin{array}{l}(1, \\
1,1 \\
)\end{array}$ & $\begin{array}{l}.2 \\
5, . \\
33, \\
.5)\end{array}$ & $\begin{array}{l}(.3 \\
3, . \\
5,1 \\
)\end{array}$ & $\begin{array}{l}.1 \\
6, .2 \\
0, .2 \\
5)\end{array}$ & $\begin{array}{l}(.2 \\
0, . \\
25, \\
.33 \\
)\end{array}$ & $\begin{array}{l}.2 \\
0, .2 \\
5, .3 \\
3)\end{array}$ & $\begin{array}{l}(.2 \\
0, .2 \\
5, .3 \\
3)\end{array}$ & $\begin{array}{l}(.2 \\
5, .3 \\
3, .5 \\
)\end{array}$ & $\begin{array}{l}.2 \\
0, .2 \\
5, .3 \\
3)\end{array}$ & $\begin{array}{l}.2 \\
0, . \\
25, \\
.33 \\
)\end{array}$ & $\begin{array}{l}(.2 \\
5, .3 \\
3, .5 \\
)\end{array}$ & $\begin{array}{l}.1 \\
6, .2 \\
0, .2 \\
5)\end{array}$ & $\begin{array}{l}.1 \\
4, .1 \\
6, .2 \\
0)\end{array}$ & $\begin{array}{l}.1 \\
6, .2 \\
0, .2 \\
5)\end{array}$ & $\begin{array}{l}(.2 \\
0, . \\
25, \\
.33 \\
)\end{array}$ & $\begin{array}{l}.2 \\
0, .2 \\
5, .3 \\
3)\end{array}$ & $\begin{array}{l}(.12 \\
. .14 \\
.16 \\
.)\end{array}$ & $\begin{array}{l}4.55,5 \\
64,7.92\end{array}$ \\
\hline $\begin{array}{l}\mathrm{L} \\
\mathrm{S} \\
\mathrm{T}\end{array}$ & $\begin{array}{l}(1, \\
2,3 \\
)\end{array}$ & $\begin{array}{l}2, \\
3,4 \\
)\end{array}$ & $\begin{array}{l}(1, \\
1,1 \\
)\end{array}$ & $\begin{array}{l}(1, \\
2,3 \\
)\end{array}$ & $\begin{array}{l}.2 \\
5, .3 \\
3, .5 \\
)\end{array}$ & $\begin{array}{l}(.2 \\
0, . \\
25, \\
.33 \\
)\end{array}$ & $\begin{array}{l}.3 \\
3, .5 \\
, 1)\end{array}$ & $\begin{array}{l}.3 \\
3, .5 \\
, 1)\end{array}$ & $\begin{array}{l}(.2 \\
5, .3 \\
3, .5 \\
)\end{array}$ & $\begin{array}{l}(.2 \\
5, .3 \\
3, .5 \\
)\end{array}$ & $\begin{array}{l}.2 \\
0, . \\
25, \\
.33 \\
)\end{array}$ & $\begin{array}{l}.3 \\
3, .5 \\
, 1)\end{array}$ & $\begin{array}{l}(.2 \\
5, .3 \\
3, .5 \\
)\end{array}$ & $\begin{array}{l}.2 \\
0, .2 \\
5, .3 \\
3)\end{array}$ & $\begin{array}{l}.2 \\
5, .3 \\
3, .5 \\
)\end{array}$ & $\begin{array}{l}(.2 \\
5, . \\
33, \\
.5)\end{array}$ & $\begin{array}{l}.2 \\
0, .2 \\
5, .3 \\
3)\end{array}$ & $\begin{array}{l}(.16 \\
, .20 \\
.25 \\
)\end{array}$ & $\begin{array}{l}8.45,12 \\
.68,18 . \\
57\end{array}$ \\
\hline $\begin{array}{l}\mathrm{S} \\
\mathrm{M} \\
\mathrm{I}\end{array}$ & $\begin{array}{l}(.3 \\
3, . \\
5,1 \\
)\end{array}$ & $\begin{array}{l}(1, \\
2,3 \\
)\end{array}$ & $\begin{array}{l}(.3 \\
3, . \\
5,1 \\
)\end{array}$ & $\begin{array}{l}(1, \\
1,1 \\
)\end{array}$ & $\begin{array}{l}(.1 \\
6, .2 \\
0, .2 \\
5)\end{array}$ & $\begin{array}{l}(.1 \\
6, . \\
20, \\
.25 \\
)\end{array}$ & $\begin{array}{l}(.2 \\
5, .3 \\
3, .5 \\
)\end{array}$ & $\begin{array}{l}(.2 \\
0, .2 \\
5, .3 \\
3)\end{array}$ & $\begin{array}{l}(.2 \\
0, .2 \\
5, .3 \\
3)\end{array}$ & $\begin{array}{l}(.3 \\
3, .5 \\
, 1)\end{array}$ & $\begin{array}{l}(.2 \\
5, . \\
33, \\
.5)\end{array}$ & $\begin{array}{l}(.2 \\
5, .3 \\
3, .5 \\
)\end{array}$ & $\begin{array}{l}(.2 \\
0, .2 \\
5, .3 \\
3)\end{array}$ & $\begin{array}{l}(.1 \\
6, .2 \\
0, .2 \\
5)\end{array}$ & $\begin{array}{l}(.3 \\
3, .5 \\
, 1)\end{array}$ & $\begin{array}{l}(.2 \\
0, . \\
25, \\
.33 \\
)\end{array}$ & $\begin{array}{l}(.2 \\
5, .3 \\
3, .5 \\
)\end{array}$ & $\begin{array}{l}(.20 \\
, .25 \\
. .33 \\
)\end{array}$ & $\begin{array}{l}5.8,8.1 \\
7,12.4\end{array}$ \\
\hline $\begin{array}{l}\mathrm{L} \\
\mathrm{U} \\
\mathrm{L} \\
\mathrm{C}\end{array}$ & $\begin{array}{l}(3, \\
4,5 \\
)\end{array}$ & $\begin{array}{l}(4, \\
5,6 \\
)\end{array}$ & $\begin{array}{l}(2, \\
3,4 \\
)\end{array}$ & $\begin{array}{l}(4, \\
5,6 \\
)\end{array}$ & $\begin{array}{l}(1, \\
1,1 \\
)\end{array}$ & $\begin{array}{l}(.3 \\
3, . \\
5,1 \\
)\end{array}$ & $\begin{array}{l}(2, \\
3,4 \\
)\end{array}$ & $\begin{array}{l}(1, \\
2,3 \\
)\end{array}$ & $\begin{array}{l}(.3 \\
3, .5 \\
, 1)\end{array}$ & $\begin{array}{l}(1, \\
2,3 \\
)\end{array}$ & $\begin{array}{l}.3 \\
3, . \\
5,1 \\
)\end{array}$ & $\begin{array}{l}(.3 \\
3, .5 \\
, 1)\end{array}$ & $\begin{array}{l}1, \\
2,3 \\
)\end{array}$ & $\begin{array}{l}(1, \\
2,3 \\
)\end{array}$ & $\begin{array}{l}.3 \\
3, .5 \\
, 1)\end{array}$ & $\begin{array}{l}(.3 \\
3, . \\
5,1 \\
)\end{array}$ & $\begin{array}{l}.3 \\
3, .5 \\
, 1)\end{array}$ & $\begin{array}{l}.25 \\
. .33 \\
. .5)\end{array}$ & $\begin{array}{l}22.56,3 \\
2.83,45 \\
.5\end{array}$ \\
\hline $\begin{array}{l}\mathrm{N} \\
\mathrm{D} \\
\mathrm{B} \\
\mathrm{I}\end{array}$ & $\begin{array}{l}(2, \\
3,4 \\
)\end{array}$ & $\begin{array}{l}(3, \\
4,5 \\
)\end{array}$ & $\begin{array}{l}(3, \\
4,5 \\
)\end{array}$ & $\begin{array}{l}(4, \\
5,6 \\
)\end{array}$ & $\begin{array}{l}(1, \\
2,3 \\
)\end{array}$ & $\begin{array}{l}(1, \\
1,1 \\
)\end{array}$ & $\begin{array}{l}(1, \\
2,3 \\
)\end{array}$ & $\begin{array}{l}(1, \\
2,3 \\
)\end{array}$ & $\begin{array}{l}(2, \\
3,4 \\
)\end{array}$ & $\begin{array}{l}(3, \\
4,5 \\
)\end{array}$ & $\begin{array}{l}(1, \\
2,3 \\
)\end{array}$ & $\begin{array}{l}(2, \\
3,4 \\
)\end{array}$ & $\begin{array}{l}\text { (1, } \\
2,3 \\
)\end{array}$ & $\begin{array}{l}(.3 \\
3, .5 \\
, 1)\end{array}$ & $\begin{array}{l}(.2 \\
5, .3 \\
3, .5 \\
)\end{array}$ & $\begin{array}{l}(.2 \\
5, . \\
33, \\
.5)\end{array}$ & $\begin{array}{l}(.3 \\
3, .5 \\
, 1)\end{array}$ & $\begin{array}{l}(.20 \\
. .25 \\
, .33 \\
. \\
\end{array}$ & $\begin{array}{l}26.28,3 \\
8.74,51 \\
.83\end{array}$ \\
\hline $\begin{array}{l}\mathrm{G} \\
\mathrm{C}\end{array}$ & $\begin{array}{l}(3, \\
4,5 \\
)\end{array}$ & $\begin{array}{l}(3, \\
4,5 \\
)\end{array}$ & $\begin{array}{l}(1, \\
2,3 \\
)\end{array}$ & $\begin{array}{l}(2, \\
3,4 \\
)\end{array}$ & $\begin{array}{l}(.2 \\
5, .3 \\
3, .5 \\
)\end{array}$ & $\begin{array}{l}(.3 \\
3, . \\
5,1 \\
)\end{array}$ & $\begin{array}{l}(1, \\
1,1 \\
)\end{array}$ & $\begin{array}{l}.3 \\
3, .5 \\
, 1)\end{array}$ & $\begin{array}{l}(.2 \\
5, .3 \\
3, .5 \\
)\end{array}$ & $\begin{array}{l}.2 \\
0, .2 \\
5, .3 \\
3)\end{array}$ & $\begin{array}{l}.2 \\
5, . \\
33, \\
.5)\end{array}$ & $\begin{array}{l}.2 \\
0, .2 \\
5, .3 \\
3)\end{array}$ & $\begin{array}{l}(.3 \\
3, .5 \\
, 1)\end{array}$ & $\begin{array}{l}(.2 \\
5, .3 \\
3, .5 \\
)\end{array}$ & $\begin{array}{l}(.2 \\
0, .2 \\
5, .3 \\
3)\end{array}$ & $\begin{array}{l}.1 \\
6, . \\
20, \\
.25 \\
)\end{array}$ & $\begin{array}{l}.2 \\
0, .2 \\
5, .3 \\
3)\end{array}$ & $\begin{array}{l}(.16 \\
, .20 \\
.25 \\
)\end{array}$ & $\begin{array}{l}13.11,1 \\
8.22,24 \\
.82\end{array}$ \\
\hline $\begin{array}{l}\mathrm{U} \\
\mathrm{C}\end{array}$ & $\begin{array}{l}(4, \\
5,6 \\
)\end{array}$ & $\begin{array}{l}3, \\
4,5 \\
)\end{array}$ & $\begin{array}{l}(1, \\
2,3 \\
)\end{array}$ & $\begin{array}{l}(3, \\
4,5 \\
)\end{array}$ & $\begin{array}{l}(.3 \\
3, .5 \\
, 1)\end{array}$ & $\begin{array}{l}(.3 \\
3, . \\
5,1 \\
)\end{array}$ & $\begin{array}{l}(1, \\
2,3 \\
)\end{array}$ & $\begin{array}{l}(1, \\
1,1 \\
)\end{array}$ & $\begin{array}{l}(.3 \\
3, .5 \\
, 1)\end{array}$ & $\begin{array}{l}(.2 \\
5, .3 \\
3, .5 \\
)\end{array}$ & $\begin{array}{l}(.2 \\
0, . \\
25, \\
.33 \\
)\end{array}$ & $\begin{array}{l}(.2 \\
5, .3 \\
3, .5 \\
)\end{array}$ & $\begin{array}{l}(.2 \\
0, .2 \\
5, .3 \\
3)\end{array}$ & $\begin{array}{l}(.2 \\
5, .3 \\
3, .5 \\
)\end{array}$ & $\begin{array}{l}(.2 \\
5, .3 \\
3, .5 \\
)\end{array}$ & $\begin{array}{l}(.2 \\
0, . \\
25, \\
.33 \\
\end{array}$ & $\begin{array}{l}(.2 \\
5, .3 \\
3, .5 \\
)\end{array}$ & $\begin{array}{l}(.20 \\
. .25 \\
, .33 \\
)\end{array}$ & $\begin{array}{l}16.04,2 \\
2.15,29 \\
.82\end{array}$ \\
\hline $\begin{array}{l}\mathrm{N} \\
\mathrm{S} \\
\mathrm{W}\end{array}$ & $\begin{array}{l}(3, \\
4,5 \\
)\end{array}$ & $\begin{array}{l}(2, \\
3,4 \\
)\end{array}$ & $\begin{array}{l}\text { (2, } \\
3,4 \\
)\end{array}$ & $\begin{array}{l}(3, \\
4,5 \\
)\end{array}$ & $\begin{array}{l}1, \\
2,3 \\
)\end{array}$ & $\begin{array}{l}.2 \\
5, . \\
33, \\
.5)\end{array}$ & $\begin{array}{l}2, \\
3,4 \\
)\end{array}$ & $\begin{array}{l}(1, \\
2,3 \\
)\end{array}$ & $\begin{array}{l}(1, \\
1,1 \\
)\end{array}$ & $\begin{array}{l}(.3 \\
3, .5 \\
, 1)\end{array}$ & $\begin{array}{l}(.3 \\
3, . \\
5,1 \\
)\end{array}$ & $\begin{array}{l}.2 \\
5, .3 \\
3, .5 \\
)\end{array}$ & $\begin{array}{l}.3 \\
3, .5 \\
, 1)\end{array}$ & $\begin{array}{l}(.2 \\
5, .3 \\
3, .5 \\
)\end{array}$ & $\begin{array}{l}.2 \\
0, .2 \\
5, .3 \\
3)\end{array}$ & $\begin{array}{l}(.1 \\
6, . \\
20, \\
.25 \\
)\end{array}$ & $\begin{array}{l}.1 \\
6, .2 \\
0, .2 \\
5)\end{array}$ & $\begin{array}{l}(.12 \\
, .14 \\
.16 \\
.)\end{array}$ & $\begin{array}{l}17.38,2 \\
5.28,34 \\
.49\end{array}$ \\
\hline $\begin{array}{l}\mathrm{N} \\
\mathrm{D} \\
\mathrm{N}\end{array}$ & $\begin{array}{l}(3, \\
4,5 \\
)\end{array}$ & $\begin{array}{l}(3, \\
4,5 \\
)\end{array}$ & $\begin{array}{l}\text { (2, } \\
3,4 \\
)\end{array}$ & $\begin{array}{l}(1, \\
2,3 \\
)\end{array}$ & $\begin{array}{l}(.3 \\
3, .5 \\
, 1)\end{array}$ & $\begin{array}{l}(.2 \\
0, . \\
25, \\
.33 \\
)\end{array}$ & $\begin{array}{l}(3, \\
4,5 \\
)\end{array}$ & $\begin{array}{l}(2, \\
3,4 \\
)\end{array}$ & $\begin{array}{l}(1, \\
2,3 \\
)\end{array}$ & $\begin{array}{l}(1, \\
1,1 \\
)\end{array}$ & $\begin{array}{l}(.3 \\
3, . \\
5,1 \\
)\end{array}$ & $\begin{array}{l}(.2 \\
5, .3 \\
3, .5 \\
)\end{array}$ & $\begin{array}{l}(.3 \\
3, .5 \\
, 1)\end{array}$ & $\begin{array}{l}(.2 \\
5, .3 \\
3, .5 \\
)\end{array}$ & $\begin{array}{l}(.2 \\
0, .2 \\
5, .3 \\
3)\end{array}$ & $\begin{array}{l}(.2 \\
0, . \\
25, \\
.33 \\
\\
\end{array}$ & $\begin{array}{l}(.1 \\
6, .2 \\
0, .2 \\
5)\end{array}$ & $\begin{array}{l}(.20 \\
, .25 \\
.33 \\
.3\end{array}$ & $\begin{array}{l}18.45,2 \\
6.36,35 \\
.57\end{array}$ \\
\hline $\begin{array}{l}\mathrm{N} \\
\mathrm{R} \\
\mathrm{L}\end{array}$ & $\begin{array}{l}(2, \\
3,4 \\
)\end{array}$ & $\begin{array}{l}(3, \\
4,5 \\
)\end{array}$ & $\begin{array}{l}(3, \\
4,5 \\
)\end{array}$ & $\begin{array}{l}(2, \\
3,4 \\
)\end{array}$ & $\begin{array}{l}(1, \\
2,3 \\
)\end{array}$ & $\begin{array}{l}(.3 \\
3, . \\
5,1 \\
)\end{array}$ & $\begin{array}{l}2, \\
3,4 \\
)\end{array}$ & $\begin{array}{l}(3, \\
4,5 \\
)\end{array}$ & $\begin{array}{l}(1, \\
2,3 \\
)\end{array}$ & $\begin{array}{l}(1, \\
2,3 \\
)\end{array}$ & $\begin{array}{l}(1, \\
1,1 \\
)\end{array}$ & $\begin{array}{l}.3 \\
3, .5 \\
, 1)\end{array}$ & $\begin{array}{l}.3 \\
3, .5 \\
, 1)\end{array}$ & $\begin{array}{l}(.2 \\
5, .3 \\
3, .5 \\
)\end{array}$ & $\begin{array}{l}.2 \\
0, .2 \\
5, .3 \\
3)\end{array}$ & $\begin{array}{l}.1 \\
6, . \\
20, \\
.25 \\
)\end{array}$ & $\begin{array}{l}.2 \\
5, .3 \\
3, .5 \\
)\end{array}$ & $\begin{array}{l}(.16 \\
, .20 \\
.25 \\
.2\end{array}$ & $\begin{array}{l}21.01,3 \\
0.81,41 \\
.83\end{array}$ \\
\hline $\begin{array}{l}\mathrm{N} \\
\mathrm{N} \\
\mathrm{H}\end{array}$ & $\begin{array}{l}(3, \\
4,5 \\
)\end{array}$ & $\begin{array}{l}(2, \\
3,4 \\
)\end{array}$ & $\begin{array}{l}(1, \\
2,3 \\
)\end{array}$ & $\begin{array}{l}(2, \\
3,4 \\
)\end{array}$ & $\begin{array}{l}(1, \\
2,3 \\
)\end{array}$ & $\begin{array}{l}(.2 \\
5, . \\
33, \\
.5)\end{array}$ & $\begin{array}{l}3, \\
4,5 \\
)\end{array}$ & $\begin{array}{l}(2, \\
3,4 \\
)\end{array}$ & $\begin{array}{l}(2, \\
3,4 \\
)\end{array}$ & $\begin{array}{l}(2, \\
3,4 \\
)\end{array}$ & $\begin{array}{l}(1, \\
2,3 \\
)\end{array}$ & $\begin{array}{l}(1, \\
1,1 \\
)\end{array}$ & $\begin{array}{l}(.2 \\
5, .3 \\
3, .5 \\
)\end{array}$ & $\begin{array}{l}.2 \\
0, .2 \\
5, .3 \\
3)\end{array}$ & $\begin{array}{l}.1 \\
6, .2 \\
0, .2 \\
5)\end{array}$ & $\begin{array}{l}.1 \\
4, . \\
16, \\
.20 \\
)\end{array}$ & $\begin{array}{l}(.2 \\
5, .3 \\
3, .5 \\
)\end{array}$ & $\begin{array}{l}(.16 \\
.20 \\
.25 \\
.)\end{array}$ & $\begin{array}{l}21.41,3 \\
1.80,42 \\
.53\end{array}$ \\
\hline $\begin{array}{l}\mathrm{N} \\
\mathrm{S} \\
\mathrm{H}\end{array}$ & $\begin{array}{l}(4, \\
5,6 \\
)\end{array}$ & $\begin{array}{l}(4, \\
5,6 \\
)\end{array}$ & $\begin{array}{l}(2, \\
3,4 \\
)\end{array}$ & $\begin{array}{l}(3, \\
4,5 \\
)\end{array}$ & $\begin{array}{l}(.3 \\
3, .5 \\
, 1)\end{array}$ & $\begin{array}{l}(.3 \\
3, . \\
5,1 \\
)\end{array}$ & $\begin{array}{l}(1, \\
2,3 \\
)\end{array}$ & $\begin{array}{l}(3, \\
4,5 \\
)\end{array}$ & $\begin{array}{l}(1, \\
2,3 \\
)\end{array}$ & $\begin{array}{l}(1, \\
2,3 \\
)\end{array}$ & $\begin{array}{l}(1, \\
2,3 \\
)\end{array}$ & $\begin{array}{l}(2, \\
3,4 \\
)\end{array}$ & $\begin{array}{l}(1, \\
1,1 \\
)\end{array}$ & $\begin{array}{l}(.2 \\
5, .3 \\
3, .5 \\
) \\
\end{array}$ & $\begin{array}{l}(.2 \\
0, .2 \\
5, .3 \\
3) \\
\end{array}$ & $\begin{array}{l}(.2 \\
5, . \\
33, \\
.5)\end{array}$ & $\begin{array}{l}(.2 \\
0, .2 \\
5, .3 \\
3) \\
\end{array}$ & $\begin{array}{l}(.25 \\
, .33 \\
, .5)\end{array}$ & $\begin{array}{l}24.81,3 \\
5.49,47 \\
.16\end{array}$ \\
\hline $\begin{array}{l}\mathrm{N} \\
\mathrm{R} \\
\mathrm{R}\end{array}$ & $\begin{array}{l}(4, \\
5,6 \\
)\end{array}$ & $\begin{array}{l}(6, \\
7,8 \\
)\end{array}$ & $\begin{array}{l}(3, \\
4,5 \\
)\end{array}$ & $\begin{array}{l}(4, \\
5,6 \\
)\end{array}$ & $\begin{array}{l}(.3 \\
3, .5 \\
, 1)\end{array}$ & $\begin{array}{l}(1, \\
2,3 \\
)\end{array}$ & $\begin{array}{l}(2, \\
3,4 \\
)\end{array}$ & $\begin{array}{l}(2, \\
3,4 \\
)\end{array}$ & $\begin{array}{l}(2, \\
3,4 \\
)\end{array}$ & $\begin{array}{l}(2, \\
3,4 \\
)\end{array}$ & $\begin{array}{l}(2, \\
3,4 \\
)\end{array}$ & $\begin{array}{l}(3, \\
4,5 \\
)\end{array}$ & $\begin{array}{l}(2, \\
3,4 \\
)\end{array}$ & $\begin{array}{l}(1, \\
1,1 \\
)\end{array}$ & $\begin{array}{l}(.1 \\
6, .2 \\
0, .2 \\
5)\end{array}$ & $\begin{array}{l}(.1 \\
6, . \\
20, \\
.25 \\
) \\
\end{array}$ & $\begin{array}{l}(.2 \\
0, .2 \\
5, .3 \\
3)\end{array}$ & $\begin{array}{l}(.25 \\
, .33 \\
. .5)\end{array}$ & $\begin{array}{l}35.1,47 \\
.48,60 \text {. } \\
33\end{array}$ \\
\hline $\begin{array}{l}\mathrm{N} \\
\mathrm{H} \\
\mathrm{C}\end{array}$ & $\begin{array}{l}(3, \\
4,5 \\
) \\
\end{array}$ & $\begin{array}{l}(4, \\
5,6 \\
) \\
\end{array}$ & $\begin{array}{l}2, \\
3,4 \\
)\end{array}$ & $\begin{array}{l}(1, \\
2,3 \\
)\end{array}$ & $\begin{array}{l}1, \\
2,3 \\
)\end{array}$ & $\begin{array}{l}(2, \\
3,4 \\
)\end{array}$ & $\begin{array}{l}3, \\
4,5 \\
) \\
\end{array}$ & $\begin{array}{l}(2, \\
3,4 \\
)\end{array}$ & $\begin{array}{l}(3, \\
4,5 \\
) \\
\end{array}$ & $\begin{array}{l}3, \\
4,5 \\
) \\
\end{array}$ & $\begin{array}{l}(3, \\
4,5 \\
)\end{array}$ & $\begin{array}{l}(4, \\
5,6 \\
)\end{array}$ & $\begin{array}{l}3, \\
4,5 \\
)\end{array}$ & $\begin{array}{l}4, \\
5,6 \\
) \\
\end{array}$ & $\begin{array}{l}(1, \\
1,1 \\
)\end{array}$ & $\begin{array}{l}(1, \\
2,3 \\
)\end{array}$ & $\begin{array}{l}.3 \\
3, .5 \\
, 1) \\
\end{array}$ & $\begin{array}{l}.25 \\
. .33 \\
, .5) \\
\end{array}$ & $\begin{array}{l}40.75,5 \\
6.33,70 \\
.5\end{array}$ \\
\hline
\end{tabular}




\begin{tabular}{|c|c|c|c|c|c|c|c|c|c|c|c|c|c|c|c|c|c|c|c|}
\hline $\mathrm{N}$ & $(2$, & (3, & $(2$, & (3, & $(1$, & $(2$, & $(4$, & $(3$, & $(4$, & (3, & $(4$, & $(5$, & $(2$, & $(4$, & $(.3$ & $(1$, & $(.2$ & $(.16$ & $43.74,5$ \\
\hline $\mathrm{P}$ & 3,4 & 4,5 & 3,4 & 4,5 & 2,3 & 3,4 & 5,6 & 4,5 & 5,6 & 4,5 & 5,6 & 6,7 & 3,4 & 5,6 & $3, .5$ & 1,1 & $5, .3$ &, 20 & $8.03,71$ \\
\hline $\mathrm{R}$ & ) & ) & ) & ) & ) & ) & ) & ) & ) & ) & ) & ) & ) & ) & ,1) & ) & $\begin{array}{l}3, .5 \\
)^{3}\end{array}$ & ${ }^{, .25}$ & .75 \\
\hline $\mathrm{D}$ & $(4$, & (3, & $(3$, & $(2$, & $(1$, & $(1$, & $(3$, & $(2$, & $(4$, & $(4$, & $(2$, & $(2$, & $(3$, & $(3$, & $(1$, & $(2$, & (1, & $(.25$ & $41.25,5$ \\
\hline W & 5,6 & 4,5 & 4,5 & 3,4 & 2,3 & 2,3 & 4,5 & 3,4 & 5,6 & 5,6 & 3,4 & 3,4 & 4,5 & 4,5 & 2,3 & 3,4 & 1,1 &, .33 & $7.33,73$ \\
\hline $\mathrm{B}$ & ) & ) & ) & ) & ) & ) & ) & ) & ) & ) & ) & ) & ) & ) & ) & ) & ) & $, .5)$ & .50 \\
\hline $\mathrm{L}$ & $(5$, & $(6$, & $(4$, & $(3$, & $(2$, & $(3$, & $(4$, & $(3$, & $(6$, & $(3$, & $(4$, & $(4$, & $(2$, & $(2$, & $(2$, & $(4$, & $(2$, & $(1,1$ & $60,77,9$ \\
\hline V & 6,7 & 7,8 & 5,6 & 4,5 & 3,4 & 4,5 & 5,6 & 4,5 & 7,8 & 4,5 & 5,6 & 5,6 & 3,4 & 3,4 & 3,4 & 5,6 & 3,4 & ,1) & 4 \\
\hline & ) & ) & ) & ) & ) & ) & ) & ) & ) & ) & ) & & ) & ) & & & & & \\
\hline
\end{tabular}

Note: $\mathrm{LE}=$ land elevation, $\mathrm{LS}=$ slope, $\mathrm{LST}=$ land surface temperature, $\mathrm{SMI}=$ soil moisture index, $\mathrm{LULC}=$ land use and land cover, NDBI = normalized difference built-up index, NDVI $=$ normalized difference vegetation index, $\mathrm{UC}=$ urban concentration, $\mathrm{NSW}=$ nearness to surface waterbodies, $\mathrm{NDN}=$ nearness to drains, $\mathrm{NRL}=$ nearness to railway line, $\mathrm{NNH}=$ nearness to national highway, $\mathrm{NSH}=$ nearness to state highway, NRR = nearness to residential roads, $\mathrm{NHC}=$ nearness to hospital and clinic, $\mathrm{NPR}=$ nearness to park, $\mathrm{DWB}=$ distance from waste bins, and LV = land value

Table 6 The degree possibility and weight of each criteria/thematic layer considered for sanitary landfill site selection

\begin{tabular}{|c|c|c|c|c|c|}
\hline $\begin{array}{l}\text { Land } \\
\text { elevation }\end{array}$ & Slope & $\begin{array}{l}\text { Land surface } \\
\text { temperature }\end{array}$ & $\begin{array}{l}\text { Soil } \\
\text { moisture } \\
\text { index }\end{array}$ & $\begin{array}{l}\text { Land use and } \\
\text { land cover }\end{array}$ & $\begin{array}{l}\text { Normalized } \\
\text { difference } \\
\text { built-up } \\
\text { index }\end{array}$ \\
\hline $\begin{array}{l}\mathrm{V}(\mathrm{S} 1 \geq \mathrm{S} 2)= \\
1.00\end{array}$ & $\begin{array}{l}\mathrm{V}(\mathrm{S} 2 \geq \mathrm{S} 1)= \\
0.66\end{array}$ & $\begin{array}{l}\mathrm{V}(\mathrm{S} 3 \geq \mathrm{S} 1)= \\
1.00\end{array}$ & $\begin{array}{l}\mathrm{V}(\mathrm{S} 4 \geq \mathrm{S} 1) \\
=0.94\end{array}$ & $\begin{array}{l}\mathrm{V}(\mathrm{S} 5 \geq \mathrm{S} 1)= \\
1.00\end{array}$ & $\begin{array}{l}\mathrm{V}(\mathrm{S} 6 \geq \mathrm{S} 1) \\
=1.00\end{array}$ \\
\hline $\begin{array}{l}\mathrm{V}(\mathrm{S} 1 \geq \mathrm{S} 3)= \\
0.75\end{array}$ & $\begin{array}{l}\mathrm{V}(\mathrm{S} 2 \geq \mathrm{S} 3)= \\
0.39\end{array}$ & $\begin{array}{l}\mathrm{V}(\mathrm{S} 3 \geq \mathrm{S} 2)= \\
1.00\end{array}$ & $\begin{array}{l}\mathrm{V}(\mathrm{S} 4 \geq \mathrm{S} 2) \\
=1.00\end{array}$ & $\begin{array}{l}\mathrm{V}(\mathrm{S} 5 \geq \mathrm{S} 2)= \\
1.00\end{array}$ & $\begin{array}{l}\mathrm{V}(\mathrm{S} 6 \geq \mathrm{S} 2) \\
=1.00\end{array}$ \\
\hline $\begin{array}{l}\mathrm{V}(\mathrm{S} 1 \geq \mathrm{S} 4)= \\
1.00\end{array}$ & $\begin{array}{l}\mathrm{V}(\mathrm{S} 2 \geq \mathrm{S} 4)= \\
0.72\end{array}$ & $\begin{array}{l}\mathrm{V}(\mathrm{S} 3 \geq \mathrm{S} 4)= \\
1.00\end{array}$ & $\begin{array}{l}\mathrm{V}(\mathrm{S} 4 \geq \mathrm{S} 3) \\
=0.70\end{array}$ & $\begin{array}{l}\mathrm{V}(\mathrm{S} 5 \geq \mathrm{S} 3)= \\
1.00\end{array}$ & $\begin{array}{l}\mathrm{V}(\mathrm{S} 6 \geq \mathrm{S} 3) \\
=1.00\end{array}$ \\
\hline $\begin{array}{l}\mathrm{V}(\mathrm{S} 1 \geq \mathrm{S} 5)= \\
0.01\end{array}$ & $\begin{array}{l}\mathrm{V}(\mathrm{S} 2 \geq \mathrm{S} 5)= \\
0.00\end{array}$ & $\begin{array}{l}\mathrm{V}(\mathrm{S} 3 \geq \mathrm{S} 5)= \\
0.30\end{array}$ & $\begin{array}{l}\mathrm{V}(\mathrm{S} 4 \geq \mathrm{S} 5) \\
=0.01\end{array}$ & $\begin{array}{l}\mathrm{V}(\mathrm{S} 5 \geq \mathrm{S} 4)= \\
1.00\end{array}$ & $\begin{array}{l}\mathrm{V}(\mathrm{S} 6 \geq \mathrm{S} 4) \\
=1.00\end{array}$ \\
\hline $\begin{array}{l}\mathrm{V}(\mathrm{S} 1 \geq \mathrm{S} 6)= \\
0.00\end{array}$ & $\begin{array}{l}\mathrm{V}(\mathrm{S} 2 \geq \mathrm{S} 6)= \\
0.00\end{array}$ & $\begin{array}{l}V(S 3 \geq S 6)= \\
0.18\end{array}$ & $\begin{array}{l}V(S 4 \geq S 6) \\
=0.00\end{array}$ & $\begin{array}{l}\mathrm{V}(\mathrm{S} 5 \geq \mathrm{S} 6)= \\
0.88\end{array}$ & $\begin{array}{l}\mathrm{V}(\mathrm{S} 6 \geq \mathrm{S} 5) \\
=1.00\end{array}$ \\
\hline $\begin{array}{l}\mathrm{V}(\mathrm{S} 1 \geq \mathrm{S} 7)= \\
0.45\end{array}$ & $\begin{array}{l}\mathrm{V}(\mathrm{S} 2 \geq \mathrm{S} 7)= \\
0.07\end{array}$ & $\begin{array}{l}\mathrm{V}(\mathrm{S} 3 \geq \mathrm{S} 7)= \\
0.74\end{array}$ & $\begin{array}{l}\mathrm{V}(\mathrm{S} 4 \geq \mathrm{S} 7) \\
=0.42\end{array}$ & $\begin{array}{l}\mathrm{V}(\mathrm{S} 5 \geq \mathrm{S} 7)= \\
1.00\end{array}$ & $\begin{array}{l}\mathrm{V}(\mathrm{S} 6 \geq \mathrm{S} 7) \\
=1.00\end{array}$ \\
\hline $\begin{array}{l}\mathrm{V}(\mathrm{S} 1 \geq \mathrm{S} 8)= \\
0.29\end{array}$ & $\begin{array}{l}\mathrm{V}(\mathrm{S} 2 \geq \mathrm{S} 8)= \\
0.00\end{array}$ & $\begin{array}{l}\mathrm{V}(\mathrm{S} 3 \geq \mathrm{S} 8)= \\
0.59\end{array}$ & $\begin{array}{l}\mathrm{V}(\mathrm{S} 4 \geq \mathrm{S} 8) \\
=0.26\end{array}$ & $\begin{array}{l}\mathrm{V}(\mathrm{S} 5 \geq \mathrm{S} 8)= \\
1.00\end{array}$ & $\begin{array}{l}\mathrm{V}(\mathrm{S} 6 \geq \mathrm{S} 8) \\
=1.00\end{array}$ \\
\hline $\begin{array}{l}\mathrm{V}(\mathrm{S} 1 \geq \mathrm{S} 9)= \\
0.21\end{array}$ & $\begin{array}{l}\mathrm{V}(\mathrm{S} 2 \geq \mathrm{S} 9)= \\
0.00\end{array}$ & $\begin{array}{l}\mathrm{V}(\mathrm{S} 3 \geq \mathrm{S} 9)= \\
0.50\end{array}$ & $\begin{array}{l}\mathrm{V}(\mathrm{S} 4 \geq \mathrm{S} 9) \\
=0.19\end{array}$ & $\begin{array}{l}\mathrm{V}(\mathrm{S} 5 \geq \mathrm{S} 9)= \\
1.00\end{array}$ & $\begin{array}{l}\mathrm{V}(\mathrm{S} 6 \geq \mathrm{S} 9) \\
=1.00\end{array}$ \\
\hline $\begin{array}{l}\mathrm{V}(\mathrm{S} 1 \geq \mathrm{S} 10) \\
=0.17\end{array}$ & $\begin{array}{l}\mathrm{V}(\mathrm{S} 2 \geq \mathrm{S} 10)= \\
0.00\end{array}$ & $\begin{array}{l}\mathrm{V}(\mathrm{S} 3 \geq \mathrm{S} 10) \\
=0.46\end{array}$ & $\begin{array}{l}\mathrm{V}(\mathrm{S} 4 \geq \mathrm{S} 10) \\
=0.15\end{array}$ & $\begin{array}{l}\mathrm{V}(\mathrm{S} 5 \geq \mathrm{S} 10) \\
=1.00\end{array}$ & $\begin{array}{l}\mathrm{V}(\mathrm{S} 6 \geq \mathrm{S} 10) \\
=1.00\end{array}$ \\
\hline $\begin{array}{l}\mathrm{V}(\mathrm{S} 1 \geq \mathrm{S} 11) \\
=0.07\end{array}$ & $\begin{array}{l}\mathrm{V}(\mathrm{S} 2 \geq \mathrm{S} 11)= \\
0.00\end{array}$ & $\begin{array}{l}\mathrm{V}(\mathrm{S} 3 \geq \mathrm{S} 11) \\
=0.35\end{array}$ & $\begin{array}{l}\mathrm{V}(\mathrm{S} 4 \geq \mathrm{S} 11) \\
=0.05\end{array}$ & $\begin{array}{l}\mathrm{V}(\mathrm{S} 5 \geq \mathrm{S} 11) \\
=1.00\end{array}$ & $\begin{array}{l}\mathrm{V}(\mathrm{S} 6 \geq \mathrm{S} 11) \\
=1.00\end{array}$ \\
\hline $\begin{array}{l}\mathrm{V}(\mathrm{S} 1 \geq \mathrm{S} 12) \\
=0.05\end{array}$ & $\begin{array}{l}\mathrm{V}(\mathrm{S} 2 \geq \mathrm{S} 12)= \\
0.00\end{array}$ & $\begin{array}{l}\mathrm{V}(\mathrm{S} 3 \geq \mathrm{S} 12) \\
=0.33\end{array}$ & $\begin{array}{l}\mathrm{V}(\mathrm{S} 4 \geq \mathrm{S} 12) \\
=0.03\end{array}$ & $\begin{array}{l}\mathrm{V}(\mathrm{S} 5 \geq \mathrm{S} 12) \\
=1.00\end{array}$ & $\begin{array}{l}\mathrm{V}(\mathrm{S} 6 \geq \mathrm{S} 12) \\
=1.00\end{array}$ \\
\hline $\begin{array}{l}\mathrm{V}(\mathrm{S} 1 \geq \mathrm{S} 13) \\
=0.00\end{array}$ & $\begin{array}{l}\mathrm{V}(\mathrm{S} 2 \geq \mathrm{S} 13)= \\
0.00\end{array}$ & $\begin{array}{l}\mathrm{V}(\mathrm{S} 3 \geq \mathrm{S} 13) \\
=0.23\end{array}$ & $\begin{array}{l}\mathrm{V}(\mathrm{S} 4 \geq \mathrm{S} 13) \\
=0.00\end{array}$ & $\begin{array}{l}\mathrm{V}(\mathrm{S} 5 \geq \mathrm{S} 13) \\
=0.94\end{array}$ & $\begin{array}{l}\mathrm{V}(\mathrm{S} 6 \geq \mathrm{S} 13) \\
=1.00\end{array}$ \\
\hline
\end{tabular}




\begin{tabular}{|c|c|c|c|c|c|}
\hline $\begin{array}{l}\mathrm{V}(\mathrm{S} 1 \geq \mathrm{S} 14) \\
=0.00\end{array}$ & $\begin{array}{l}\mathrm{V}(\mathrm{S} 2 \geq \mathrm{S} 14)= \\
0.00\end{array}$ & $\begin{array}{l}\mathrm{V}(\mathrm{S} 3 \geq \mathrm{S} 14) \\
=0.00\end{array}$ & $\begin{array}{l}\mathrm{V}(\mathrm{S} 4 \geq \mathrm{S} 14) \\
=0.00\end{array}$ & $\begin{array}{l}\mathrm{V}(\mathrm{S} 5 \geq \mathrm{S} 14) \\
=0.71\end{array}$ & $\begin{array}{l}\mathrm{V}(\mathrm{S} 6 \geq \mathrm{S}) \\
=0.84\end{array}$ \\
\hline $\begin{array}{l}\mathrm{V}(\mathrm{S} 1 \geq \mathrm{S} 15) \\
=0.00\end{array}$ & $\begin{array}{l}\mathrm{V}(\mathrm{S} 2 \geq \mathrm{S} 15)= \\
0.00\end{array}$ & $\begin{array}{l}V(S 3 \geq S 15) \\
=0.00\end{array}$ & $\begin{array}{l}\mathrm{V}(\mathrm{S} 4 \geq \mathrm{S} 15) \\
=0.00\end{array}$ & $\begin{array}{l}\mathrm{V}(\mathrm{S} 5 \geq \mathrm{S} 15) \\
=0.58\end{array}$ & $\begin{array}{l}\mathrm{V}(\mathrm{S} 6 \geq \mathrm{S}) \\
=0.70\end{array}$ \\
\hline $\begin{array}{l}\mathrm{V}(\mathrm{S} 1 \geq \mathrm{S} 16) \\
=0.00\end{array}$ & $\begin{array}{l}\mathrm{V}(\mathrm{S} 2 \geq \mathrm{S} 16)= \\
0.00\end{array}$ & $\begin{array}{l}V(S 3 \geq S 16) \\
=0.00\end{array}$ & $\begin{array}{l}\mathrm{V}(\mathrm{S} 4 \geq \mathrm{S} 16) \\
=0.00\end{array}$ & $\begin{array}{l}V(S 5 \geq S 16) \\
=0.54\end{array}$ & $\begin{array}{l}V(S 6 \geq S 16) \\
=0.67\end{array}$ \\
\hline $\begin{array}{l}\mathrm{V}(\mathrm{S} 1 \geq \mathrm{S} 17) \\
=0.00\end{array}$ & $\begin{array}{l}\mathrm{V}(\mathrm{S} 2 \geq \mathrm{S} 17)= \\
0.00\end{array}$ & $\begin{array}{l}\mathrm{V}(\mathrm{S} 3 \geq \mathrm{S} 17) \\
=0.00\end{array}$ & $\begin{array}{l}\mathrm{V}(\mathrm{S} 4 \geq \mathrm{S} 17) \\
=0.00\end{array}$ & $\begin{array}{l}\mathrm{V}(\mathrm{S} 5 \geq \mathrm{S} 17) \\
=0.56\end{array}$ & $\begin{array}{l}\mathrm{V}(\mathrm{S} 6 \geq \mathrm{S} 17) \\
=0.69\end{array}$ \\
\hline $\begin{array}{l}\mathrm{V}(\mathrm{S} 1 \geq \mathrm{S} 18) \\
=0.00\end{array}$ & $\begin{array}{l}\mathrm{V}(\mathrm{S} 2 \geq \mathrm{S} 18)= \\
0.00\end{array}$ & $\begin{array}{l}V(S 3 \geq S 18) \\
=0.00\end{array}$ & $\begin{array}{l}\mathrm{V}(\mathrm{S} 4 \geq \mathrm{S} 18) \\
=0.00\end{array}$ & $\begin{array}{l}\mathrm{V}(\mathrm{S} 5 \geq \mathrm{S} 18) \\
=0.28\end{array}$ & $\begin{array}{l}\mathrm{V}(\mathrm{S} 6 \geq \mathrm{S} 18) \\
=0.41\end{array}$ \\
\hline $\begin{array}{l}\min \left\{\mathrm{V}\left(\mathrm{S}_{1} \geq\right.\right. \\
\left.\left.\mathrm{S}_{\mathrm{k}}\right)\right\}=0 \\
\text { Weight }=0\end{array}$ & $\begin{array}{l}\min \left\{\mathrm{V}\left(\mathrm{S}_{2} \geq\right.\right. \\
\left.\left.\mathrm{S}_{\mathrm{k}}\right)\right\}=0 \\
\text { Weight }=0\end{array}$ & $\begin{array}{l}\min \left\{\mathrm{V}\left(\mathrm{S}_{3} \geq\right.\right. \\
\left.\left.\mathrm{S}_{\mathrm{k}}\right)\right\}=0 \\
\text { Weight }=0\end{array}$ & $\begin{array}{l}\min \left\{\mathrm{V}\left(\mathrm{S}_{4} \geq\right.\right. \\
\left.\left.\mathrm{S}_{\mathrm{k}}\right)\right\}=0 \\
\text { Weight }=0\end{array}$ & $\begin{array}{l}\min \left\{\mathrm{V}\left(\mathrm{S}_{5} \geq\right.\right. \\
\left.\left.\mathrm{S}_{\mathrm{k}}\right)\right\}=0.28 \\
\text { Weight }= \\
0.0531\end{array}$ & $\begin{array}{l}\min \left\{\mathrm{V}\left(\mathrm{S}_{6} \geq\right.\right. \\
\left.\left.\mathrm{S}_{\mathrm{k}}\right)\right\}=0.41 \\
\text { Weight }= \\
0.0764\end{array}$ \\
\hline $\begin{array}{l}\text { Normalized } \\
\text { difference } \\
\text { vegetation } \\
\text { index }\end{array}$ & $\begin{array}{l}\text { Urban } \\
\text { concentration }\end{array}$ & $\begin{array}{l}\text { Nearness to } \\
\text { surface } \\
\text { waterbodies }\end{array}$ & $\begin{array}{l}\text { arness to } \\
\text { ains }\end{array}$ & $\begin{array}{l}\text { arness to } \\
\text { lway line }\end{array}$ & $\begin{array}{l}\text { Nearness to } \\
\text { national } \\
\text { highway }\end{array}$ \\
\hline $\begin{array}{l}\mathrm{V}(\mathrm{S} 7 \geq \mathrm{S} 1)= \\
1.00\end{array}$ & $\begin{array}{l}(\mathrm{S} 8 \geq \mathrm{S} 1)= \\
00\end{array}$ & $\begin{array}{l}S 9 \geq \mathrm{S} 1)= \\
0\end{array}$ & $\begin{array}{l}(\mathrm{S} 10 \geq \mathrm{S} 1) \\
1.00\end{array}$ & $\begin{array}{l}(\mathrm{S} 11 \geq \mathrm{S} 1) \\
1.00\end{array}$ & $\begin{array}{l}\mathrm{V}(\mathrm{S} 12 \geq \mathrm{S} 1) \\
=1.00\end{array}$ \\
\hline $\begin{array}{l}\mathrm{V}(\mathrm{S} 7 \geq \mathrm{S} 2)= \\
1.00\end{array}$ & $\begin{array}{l}(\mathrm{S} 8 \geq \mathrm{S} 2)= \\
.00\end{array}$ & $\begin{array}{l}J(\mathrm{~S} 9 \geq \mathrm{S} 2)= \\
.00\end{array}$ & $\begin{array}{l}(\mathrm{S} 10 \geq \mathrm{S} 2) \\
1.00\end{array}$ & $\begin{array}{l}(\mathrm{S} 11 \geq \mathrm{S} 2) \\
1.00\end{array}$ & $\begin{array}{l}V(\mathrm{~S} 12 \geq \mathrm{S} 2) \\
=1.00\end{array}$ \\
\hline $\begin{array}{l}\mathrm{V}(\mathrm{S} 7 \geq \mathrm{S} 3)= \\
1.00\end{array}$ & $\begin{array}{l}J(\mathrm{~S} 6 \geq \mathrm{S} 3)= \\
.00\end{array}$ & $\begin{array}{l}(\mathrm{S} 9 \geq \mathrm{S} 3)= \\
00\end{array}$ & $\begin{array}{l}(\mathrm{S} 10 \geq \mathrm{S} 3) \\
1.00\end{array}$ & $\begin{array}{l}\mathrm{V}(\mathrm{S} 11 \geq \mathrm{S} 3) \\
=1.00\end{array}$ & $\begin{array}{l}\mathrm{V}(\mathrm{S} 12 \geq \mathrm{S} 3) \\
=1.00\end{array}$ \\
\hline $\begin{array}{l}\mathrm{V}(\mathrm{S} 7 \geq \mathrm{S} 4)= \\
1.00\end{array}$ & $\begin{array}{l}(S 8 \geq S 4)= \\
00\end{array}$ & $\begin{array}{l}S 9 \geq S 4)= \\
0\end{array}$ & $\begin{array}{l}\mathrm{S} 10 \geq \mathrm{S} 4) \\
1.00\end{array}$ & $\begin{array}{l}\mathrm{S} 11 \geq \mathrm{S} 4) \\
1.00\end{array}$ & $\begin{array}{l}\mathrm{V}(\mathrm{S} 12 \geq \mathrm{S} 4) \\
=1.00\end{array}$ \\
\hline $\begin{array}{l}\mathrm{V}(\mathrm{S} 7 \geq \mathrm{S} 5)= \\
0.54\end{array}$ & $\begin{array}{l}(\mathrm{S} 8 \geq \mathrm{S} 5)= \\
69\end{array}$ & $\begin{array}{l}(\mathrm{S} 9 \geq \mathrm{S} 5)= \\
80\end{array}$ & $\begin{array}{l}(\mathrm{S} 10 \geq \mathrm{S} 5) \\
0.83\end{array}$ & $\begin{array}{l}\mathrm{V}(\mathrm{S} 11 \geq \mathrm{S} 5) \\
=0.95\end{array}$ & $\begin{array}{l}V(S 12 \geq S 5) \\
=0.98\end{array}$ \\
\hline $\begin{array}{l}\mathrm{V}(\mathrm{S} 7 \geq \mathrm{S} 6)= \\
0.41\end{array}$ & $\begin{array}{l}(\mathrm{S} 8 \geq \mathrm{S} 6)= \\
56\end{array}$ & $\begin{array}{l}(S 9 \geq S 6)= \\
67\end{array}$ & $\begin{array}{l}V(\mathrm{~S} 10 \geq \mathrm{S} 6) \\
=0.70\end{array}$ & $\begin{array}{l}\mathrm{V}(\mathrm{S} 11 \geq \mathrm{S} 6) \\
=0.83\end{array}$ & $\begin{array}{l}\mathrm{V}(\mathrm{S} 12 \geq \mathrm{S} 6) \\
=0.85\end{array}$ \\
\hline $\begin{array}{l}\mathrm{V}(\mathrm{S} 7 \geq \mathrm{S} 8)= \\
0.85\end{array}$ & $\begin{array}{l}(S 8 \geq S 7)= \\
00\end{array}$ & $59 \geq$ S7) $=$ & $\begin{array}{l}\mathrm{V}(\mathrm{S} 10 \geq \mathrm{S} 7) \\
=1.00\end{array}$ & $\begin{array}{l}\mathrm{V}(\mathrm{S} 11 \geq \mathrm{S} 7) \\
=1.00\end{array}$ & $\begin{array}{l}\mathrm{V}(\mathrm{S} 12 \geq \mathrm{S} 7) \\
=1.00\end{array}$ \\
\hline $\begin{array}{l}\mathrm{V}(\mathrm{S} 7 \geq \mathrm{S} 9)= \\
0.75\end{array}$ & $\begin{array}{l}\mathrm{V}(\mathrm{S} 8 \geq \mathrm{S} 9)= \\
0.90\end{array}$ & $\begin{array}{l}S 9 \geq S 8)= \\
0\end{array}$ & $\begin{array}{l}(\mathrm{S} 10 \geq \mathrm{S} 8) \\
1.00\end{array}$ & $\begin{array}{l}\mathrm{V}(\mathrm{S} 11 \geq \mathrm{S} 8) \\
=1.00\end{array}$ & $\begin{array}{l}\mathrm{V}(\mathrm{S} 12 \geq \mathrm{S} 8) \\
=1.00\end{array}$ \\
\hline $\begin{array}{l}V(S 7 \geq S 10) \\
=0.71\end{array}$ & $\begin{array}{l}(\mathrm{S} 8 \geq \mathrm{S} 10)= \\
87\end{array}$ & $\begin{array}{l}V(S 9 \geq S 10) \\
=0.97\end{array}$ & $\begin{array}{l}\mathrm{V}(\mathrm{S} 10 \geq \mathrm{S} 9) \\
=1.00\end{array}$ & $\begin{array}{l}\mathrm{V}(\mathrm{S} 11 \geq \mathrm{S} 9) \\
=1.00\end{array}$ & $\begin{array}{l}\mathrm{V}(\mathrm{S} 12 \geq \mathrm{S} 9) \\
=1.00\end{array}$ \\
\hline $\begin{array}{l}\mathrm{V}(\mathrm{S} 7 \geq \mathrm{S} 11) \\
=0.59\end{array}$ & $\begin{array}{l}\mathrm{V}(\mathrm{S} 8 \geq \mathrm{S} 11)= \\
0.75\end{array}$ & $\begin{array}{l}\mathrm{V}(\mathrm{S} 9 \geq \mathrm{S} 11) \\
=0.85\end{array}$ & $\begin{array}{l}\mathrm{V}(\mathrm{S} 10 \geq \\
\mathrm{S} 11)=0.88\end{array}$ & $\begin{array}{l}\mathrm{V}(\mathrm{S} 11 \geq \\
\mathrm{S} 10)=1.00\end{array}$ & $\begin{array}{l}\mathrm{V}(\mathrm{S} 12 \geq \\
\mathrm{S} 10)=1.00\end{array}$ \\
\hline $\begin{array}{l}\mathrm{V}(\mathrm{S} 7 \geq \mathrm{S} 12) \\
=0.57\end{array}$ & $\begin{array}{l}\mathrm{V}(\mathrm{S} 8 \geq \mathrm{S} 12)= \\
0.72\end{array}$ & $\begin{array}{l}\mathrm{V}(\mathrm{S} 9 \geq \mathrm{S} 12) \\
=0.83\end{array}$ & $\begin{array}{l}\mathrm{V}(\mathrm{S} 10 \geq \\
\mathrm{S} 12)=0.86\end{array}$ & $\begin{array}{l}\mathrm{V}(\mathrm{S} 11 \geq \\
\mathrm{S} 12)=0.98\end{array}$ & $\begin{array}{l}\mathrm{V}(\mathrm{S} 12 \geq \\
\mathrm{S} 11)=1.00\end{array}$ \\
\hline $\begin{array}{l}\mathrm{V}(\mathrm{S} 7 \geq \mathrm{S} 13) \\
=0.47\end{array}$ & $\begin{array}{l}\mathrm{V}(\mathrm{S} 8 \geq \mathrm{S} 13)= \\
0.63\end{array}$ & $\begin{array}{l}\mathrm{V}(\mathrm{S} 9 \geq \mathrm{S} 13) \\
=0.74\end{array}$ & $\begin{array}{l}\mathrm{V}(\mathrm{S} 6 \geq \mathrm{S} 13) \\
=0.77\end{array}$ & $\begin{array}{l}\mathrm{V}(\mathrm{S} 11 \geq \\
\mathrm{S} 13)=0.89\end{array}$ & $\begin{array}{l}\mathrm{V}(\mathrm{S} 12 \geq \\
\mathrm{S} 13)=0.92\end{array}$ \\
\hline $\mathrm{V}(\mathrm{S} 7 \geq \mathrm{S} 14)$ & $V(\mathrm{~S} 8 \geq \mathrm{S} 14)=$ & $\mathrm{V}(\mathrm{S} 9 \geq \mathrm{S} 14)$ & $V(\mathrm{~S} 10 \geq$ & $\mathrm{V}(\mathrm{S} 11 \geq$ & $\mathrm{V}(\mathrm{S} 12 \geq$ \\
\hline
\end{tabular}




\begin{tabular}{|c|c|c|c|c|c|}
\hline 0.21 & 0.37 & $=0.49$ & $S 14)=0.52$ & $S 14)=0.65$ & $S 14)=0.67$ \\
\hline $\begin{array}{l}V(S 7 \geq S 15) \\
=0.08\end{array}$ & $\begin{array}{l}\mathrm{V}(\mathrm{S} 8 \geq \mathrm{S} 15)= \\
0.23\end{array}$ & $\begin{array}{l}\mathrm{V}(\mathrm{S} 9 \geq \mathrm{S} 15) \\
=0.35\end{array}$ & $\begin{array}{l}\mathrm{V}(\mathrm{S} 10 \geq \\
\mathrm{S} 15)=0.38\end{array}$ & $\begin{array}{l}\mathrm{V}(\mathrm{S} 11 \geq \\
\mathrm{S} 15)=0.51\end{array}$ & $\begin{array}{l}\mathrm{V}(\mathrm{S} 12 \geq \\
\mathrm{S} 15)=0.53\end{array}$ \\
\hline $\begin{array}{l}\mathrm{V}(\mathrm{S} 7 \geq \mathrm{S} 16) \\
=0.03\end{array}$ & $\begin{array}{l}\mathrm{V}(\mathrm{S} 8 \geq \mathrm{S} 16)= \\
0.18\end{array}$ & $\begin{array}{l}\mathrm{V}(\mathrm{S} 9 \geq \mathrm{S} 16) \\
=0.31\end{array}$ & $\begin{array}{l}\mathrm{V}(\mathrm{S} 10 \geq \\
\mathrm{S} 16)=0.34\end{array}$ & $\begin{array}{l}\mathrm{V}(\mathrm{S} 11 \geq \\
\mathrm{S} 16)=0.48\end{array}$ & $\begin{array}{l}\mathrm{V}(\mathrm{S} 12 \geq \\
\mathrm{S} 16)=0.49\end{array}$ \\
\hline $\begin{array}{l}\mathrm{V}(\mathrm{S} 7 \geq \mathrm{S} 17) \\
=0.07\end{array}$ & $\begin{array}{l}\mathrm{V}(\mathrm{S} 8 \geq \mathrm{S} 17)= \\
0.22\end{array}$ & $\begin{array}{l}\mathrm{V}(\mathrm{S} 9 \geq \mathrm{S} 17) \\
=0.34\end{array}$ & $\begin{array}{l}\mathrm{V}(\mathrm{S} 10 \geq \\
\mathrm{S} 17)=0.37\end{array}$ & $\begin{array}{l}\mathrm{V}(\mathrm{S} 11 \geq \\
\mathrm{S} 17)=0.50\end{array}$ & $\begin{array}{l}\mathrm{V}(\mathrm{S} 12 \geq \\
\mathrm{S} 17)=0.52\end{array}$ \\
\hline $\begin{array}{l}\mathrm{V}(\mathrm{S} 7 \geq \mathrm{S} 18) \\
=0.00\end{array}$ & $\begin{array}{l}\mathrm{V}(\mathrm{S} 8 \geq \mathrm{S} 18)= \\
0.00\end{array}$ & $\begin{array}{l}\mathrm{V}(\mathrm{S} 9 \geq \mathrm{S} 18) \\
=0.04\end{array}$ & $\begin{array}{l}\mathrm{V}(\mathrm{S} 10 \geq \\
\mathrm{S} 18)=0.07\end{array}$ & $\begin{array}{l}\mathrm{V}(\mathrm{S} 11 \geq \\
\mathrm{S} 18)=0.21\end{array}$ & $\begin{array}{l}\mathrm{V}(\mathrm{S} 12 \geq \\
\mathrm{S} 18)=0.23\end{array}$ \\
\hline $\begin{array}{l}\min \left\{\mathrm{V}\left(\mathrm{S}_{7} \geq\right.\right. \\
\left.\left.\mathrm{S}_{\mathrm{k}}\right)\right\}=0 \\
\text { Weight }= \\
0.0000\end{array}$ & $\begin{array}{l}\min \left\{\mathrm{V}\left(\mathrm{S}_{8} \geq\right.\right. \\
\left.\left.\mathrm{S}_{\mathrm{k}}\right)\right\}=0 \\
\text { Weight }= \\
0.0000\end{array}$ & $\begin{array}{l}\min \left\{\mathrm{V}\left(\mathrm{S}_{9} \geq\right.\right. \\
\left.\left.\mathrm{S}_{\mathrm{k}}\right)\right\}=0.04 \\
\text { Weight }= \\
0.0071\end{array}$ & $\begin{array}{l}\min \left\{\mathrm{V}\left(\mathrm{S}_{10} \geq\right.\right. \\
\left.\left.\mathrm{S}_{\mathrm{k}}\right)\right\}=0.07 \\
\text { Weight }= \\
0.0122\end{array}$ & $\begin{array}{l}\min \left\{\mathrm{V}\left(\mathrm{S}_{11} \geq\right.\right. \\
\left.\left.\mathrm{S}_{\mathrm{k}}\right)\right\}=0.21 \\
\text { Weight }= \\
0.0394\end{array}$ & $\begin{array}{l}\min \left\{\mathrm{V}\left(\mathrm{S}_{12} \geq\right.\right. \\
\left.\left.\mathrm{S}_{\mathrm{k}}\right)\right\}=0.23 \\
\text { Weight }= \\
0.0426\end{array}$ \\
\hline $\begin{array}{l}\text { Nearness to } \\
\text { state } \\
\text { highway }\end{array}$ & $\begin{array}{l}\text { Nearness to } \\
\text { residential } \\
\text { roads }\end{array}$ & $\begin{array}{l}\text { Nearness to } \\
\text { hospital and } \\
\text { clinic }\end{array}$ & $\begin{array}{l}\text { Nearness to } \\
\text { park }\end{array}$ & $\begin{array}{l}\text { Distance } \\
\text { from waste } \\
\text { bins }\end{array}$ & Land value \\
\hline $\begin{array}{l}\mathrm{V}(\mathrm{S} 13 \geq \mathrm{S} 1) \\
=1.00\end{array}$ & $\begin{array}{l}\mathrm{V}(\mathrm{S} 14 \geq \mathrm{S} 1)= \\
1.00\end{array}$ & $\begin{array}{l}\mathrm{V}(\mathrm{S} 15 \geq \mathrm{S} 1) \\
=1.00\end{array}$ & $\begin{array}{l}\mathrm{V}(\mathrm{S} 16 \geq \mathrm{S} 1) \\
=1.00\end{array}$ & $\begin{array}{l}\mathrm{V}(\mathrm{S} 17 \geq \mathrm{S} 1) \\
=1.00\end{array}$ & $\begin{array}{l}\mathrm{V}(\mathrm{S} 18 \geq \mathrm{S} 1) \\
=1.00\end{array}$ \\
\hline $\begin{array}{l}\mathrm{V}(\mathrm{S} 13 \geq \mathrm{S} 2) \\
=1.00\end{array}$ & $\begin{array}{l}\mathrm{V}(\mathrm{S} 14 \geq \mathrm{S} 2)= \\
1.00\end{array}$ & $\begin{array}{l}\mathrm{V}(\mathrm{S} 15 \geq \mathrm{S} 2) \\
=1.00\end{array}$ & $\begin{array}{l}\mathrm{V}(\mathrm{S} 16 \geq \mathrm{S} 2) \\
=1.00\end{array}$ & $\begin{array}{l}\mathrm{V}(\mathrm{S} 17 \geq \mathrm{S} 2) \\
=1.00\end{array}$ & $\begin{array}{l}\mathrm{V}(\mathrm{S} 18 \geq \mathrm{S} 2) \\
=1.00\end{array}$ \\
\hline $\begin{array}{l}\mathrm{V}(\mathrm{S} 13 \geq \mathrm{S} 3) \\
=1.00\end{array}$ & $\begin{array}{l}\mathrm{V}(\mathrm{S} 14 \geq \mathrm{S} 3)= \\
1.00\end{array}$ & $\begin{array}{l}\mathrm{V}(\mathrm{S} 15 \geq \mathrm{S} 3) \\
=1.00\end{array}$ & $\begin{array}{l}\mathrm{V}(\mathrm{S} 16 \geq \mathrm{S} 3) \\
=1.00\end{array}$ & $\begin{array}{l}\mathrm{V}(\mathrm{S} 17 \geq \mathrm{S} 3) \\
=1.00\end{array}$ & $\begin{array}{l}\mathrm{V}(\mathrm{S} 18 \geq \mathrm{S} 3) \\
=1.00\end{array}$ \\
\hline $\begin{array}{l}\mathrm{V}(\mathrm{S} 13 \geq \mathrm{S} 4) \\
=1.00\end{array}$ & $\begin{array}{l}\mathrm{V}(\mathrm{S} 14 \geq \mathrm{S} 4)= \\
1.00\end{array}$ & $\begin{array}{l}\mathrm{V}(\mathrm{S} 15 \geq \mathrm{S} 4) \\
=1.00\end{array}$ & $\begin{array}{l}\mathrm{V}(\mathrm{S} 16 \geq \mathrm{S} 4) \\
=1.00\end{array}$ & $\begin{array}{l}\mathrm{V}(\mathrm{S} 17 \geq \mathrm{S} 4) \\
=1.00\end{array}$ & $\begin{array}{l}\mathrm{V}(\mathrm{S} 18 \geq \mathrm{S} 4) \\
=1.00\end{array}$ \\
\hline $\begin{array}{l}\mathrm{V}(\mathrm{S} 13 \geq \mathrm{S} 5) \\
=1.00\end{array}$ & $\begin{array}{l}\mathrm{V}(\mathrm{S} 14 \geq \mathrm{S} 5)= \\
1.00\end{array}$ & $\begin{array}{l}\mathrm{V}(\mathrm{S} 15 \geq \mathrm{S} 5) \\
=1.00\end{array}$ & $\begin{array}{l}\mathrm{V}(\mathrm{S} 16 \geq \mathrm{S} 5) \\
=1.00\end{array}$ & $\begin{array}{l}\mathrm{V}(\mathrm{S} 17 \geq \mathrm{S} 5) \\
=1.00\end{array}$ & $\begin{array}{l}\mathrm{V}(\mathrm{S} 18 \geq \mathrm{S} 5) \\
=1.00\end{array}$ \\
\hline $\begin{array}{l}\mathrm{V}(\mathrm{S} 13 \geq \mathrm{S} 6) \\
=0.93\end{array}$ & $\begin{array}{l}\mathrm{V}(\mathrm{S} 14 \geq \mathrm{S} 6)= \\
1.00\end{array}$ & $\begin{array}{l}\mathrm{V}(\mathrm{S} 15 \geq \mathrm{S} 6) \\
=1.00\end{array}$ & $\begin{array}{l}\mathrm{V}(\mathrm{S} 16 \geq \mathrm{S} 6) \\
=1.00\end{array}$ & $\begin{array}{l}\mathrm{V}(\mathrm{S} 17 \geq \mathrm{S} 6) \\
=1.00\end{array}$ & $\begin{array}{l}\mathrm{V}(\mathrm{S} 18 \geq \mathrm{S} 6) \\
=1.00\end{array}$ \\
\hline $\begin{array}{l}\mathrm{V}(\mathrm{S} 13 \geq \mathrm{S} 7) \\
=1.00\end{array}$ & $\begin{array}{l}\mathrm{V}(\mathrm{S} 14 \geq \mathrm{S} 7)= \\
1.00\end{array}$ & $\begin{array}{l}\mathrm{V}(\mathrm{S} 15 \geq \mathrm{S} 7) \\
=1.00\end{array}$ & $\begin{array}{l}\mathrm{V}(\mathrm{S} 16 \geq \mathrm{S} 7) \\
=1.00\end{array}$ & $\begin{array}{l}\mathrm{V}(\mathrm{S} 17 \geq \mathrm{S} 7) \\
=1.00\end{array}$ & $\begin{array}{l}V(S 18 \geq S 7) \\
=1.00\end{array}$ \\
\hline $\begin{array}{l}\mathrm{V}(\mathrm{S} 13 \geq \mathrm{S} 8) \\
=1.00\end{array}$ & $\begin{array}{l}\mathrm{V}(\mathrm{S} 14 \geq \mathrm{S} 8)= \\
1.00\end{array}$ & $\begin{array}{l}\mathrm{V}(\mathrm{S} 15 \geq \mathrm{S} 8) \\
=1.00\end{array}$ & $\begin{array}{l}\mathrm{V}(\mathrm{S} 16 \geq \mathrm{S} 8) \\
=1.00\end{array}$ & $\begin{array}{l}\mathrm{V}(\mathrm{S} 17 \geq \mathrm{S} 8) \\
=1.00\end{array}$ & $\begin{array}{l}\mathrm{V}(\mathrm{S} 18 \geq \mathrm{S} 8) \\
=1.00\end{array}$ \\
\hline $\begin{array}{l}\mathrm{V}(\mathrm{S} 13 \geq \mathrm{S} 9) \\
=1.00\end{array}$ & $\begin{array}{l}\mathrm{V}(\mathrm{S} 14 \geq \mathrm{S} 9)= \\
1.00\end{array}$ & $\begin{array}{l}\mathrm{V}(\mathrm{S} 15 \geq \mathrm{S} 9) \\
=1.00\end{array}$ & $\begin{array}{l}\mathrm{V}(\mathrm{S} 16 \geq \mathrm{S} 9) \\
=1.00\end{array}$ & $\begin{array}{l}\mathrm{V}(\mathrm{S} 17 \geq \mathrm{S} 9) \\
=1.00\end{array}$ & $\begin{array}{l}\mathrm{V}(\mathrm{S} 18 \geq \mathrm{S} 9) \\
=1.00\end{array}$ \\
\hline $\begin{array}{l}\mathrm{V}(\mathrm{S} 13 \geq \\
\mathrm{S} 10)=1.00\end{array}$ & $\begin{array}{l}\mathrm{V}(\mathrm{S} 14 \geq \mathrm{S} 10) \\
=1.00\end{array}$ & $\begin{array}{l}\mathrm{V}(\mathrm{S} 15 \geq \mathrm{S} 10) \\
=1.00\end{array}$ & $\begin{array}{l}\mathrm{V}(\mathrm{S} 16 \geq \\
\mathrm{S} 10)=1.00\end{array}$ & $\begin{array}{l}\mathrm{V}(\mathrm{S} 17 \geq \\
\mathrm{S} 10)=1.00\end{array}$ & $\begin{array}{l}\mathrm{V}(\mathrm{S} 18 \geq \\
\mathrm{S} 10)=1.00\end{array}$ \\
\hline $\begin{array}{l}\mathrm{V}(\mathrm{S} 13 \geq \\
\mathrm{S} 11)=1.00\end{array}$ & $\begin{array}{l}\mathrm{V}(\mathrm{S} 14 \geq \mathrm{S} 11) \\
=1.00\end{array}$ & $\begin{array}{l}\mathrm{V}(\mathrm{S} 15 \geq \mathrm{S} 11) \\
=1.00\end{array}$ & $\begin{array}{l}\mathrm{V}(\mathrm{S} 16 \geq \\
\mathrm{S} 11)=1.00\end{array}$ & $\begin{array}{l}\mathrm{V}(\mathrm{S} 17 \geq \\
\mathrm{S} 11)=1.00\end{array}$ & $\begin{array}{l}\mathrm{V}(\mathrm{S} 18 \geq \\
\mathrm{S} 11)=1.00\end{array}$ \\
\hline $\begin{array}{l}\mathrm{V}(\mathrm{S} 13 \geq \\
\mathrm{S} 12)=1.00\end{array}$ & $\begin{array}{l}\mathrm{V}(\mathrm{S} 14 \geq \mathrm{S} 12) \\
=1.00\end{array}$ & $\begin{array}{l}\mathrm{V}(\mathrm{S} 15 \geq \mathrm{S} 12) \\
=1.00\end{array}$ & $\begin{array}{l}\mathrm{V}(\mathrm{S} 16 \geq \\
\mathrm{S} 12)=1.00\end{array}$ & $\begin{array}{l}\mathrm{V}(\mathrm{S} 17 \geq \\
\mathrm{S} 12)=1.00\end{array}$ & $\begin{array}{l}\mathrm{V}(\mathrm{S} 18 \geq \\
\mathrm{S} 12)=1.00\end{array}$ \\
\hline $\begin{array}{l}\mathrm{V}(\mathrm{S} 13 \geq \\
\mathrm{S} 14)=0.76\end{array}$ & $\begin{array}{l}\mathrm{V}(\mathrm{S} 14 \geq \mathrm{S} 13) \\
=1.00\end{array}$ & $\begin{array}{l}\mathrm{V}(\mathrm{S} 15 \geq \mathrm{S} 13) \\
=1.00\end{array}$ & $\begin{array}{l}V(\mathrm{~S} 16 \geq \\
S 13)=1.00\end{array}$ & $\begin{array}{l}\mathrm{V}(\mathrm{S} 17 \geq \\
\mathrm{S} 13)=1.00\end{array}$ & $\begin{array}{l}\mathrm{V}(\mathrm{S} 18 \geq \\
\mathrm{S} 13)=1.00\end{array}$ \\
\hline $\mathrm{V}(\mathrm{S} 13 \geq$ & $\mathrm{V}(\mathrm{S} 14 \geq \mathrm{S} 15)$ & $\mathrm{V}(\mathrm{S} 15 \geq \mathrm{S} 14)$ & $\mathrm{V}(\mathrm{S} 16 \geq$ & $\mathrm{V}(\mathrm{S} 17 \geq$ & $\mathrm{V}(\mathrm{S} 18 \geq$ \\
\hline
\end{tabular}




\begin{tabular}{|l|l|l|l|l|l|}
\hline $\mathrm{S} 15)=0.62$ & $=0.86$ & $=1.00$ & $\mathrm{~S} 14)=1.00$ & $\mathrm{~S} 14)=1.00$ & $\mathrm{~S} 14)=1.00$ \\
\hline $\mathrm{V}(\mathrm{S} 13 \geq$ & $\mathrm{V}(\mathrm{S} 14 \geq \mathrm{S} 16)$ & $\mathrm{V}(\mathrm{S} 15 \geq \mathrm{S} 16)$ & $\mathrm{V}(\mathrm{S} 16 \geq$ & $\mathrm{V}(\mathrm{S} 17 \geq$ & $\mathrm{V}(\mathrm{S} 18 \geq$ \\
$\mathrm{S} 16)=0.59$ & $=0.83$ & $=0.97$ & $\mathrm{~S} 15)=1.00$ & $\mathrm{~S} 15)=1.00$ & $\mathrm{~S} 15)=1.00$ \\
\hline $\mathrm{V}(\mathrm{S} 13 \geq$ & $\mathrm{V}(\mathrm{S} 14 \geq \mathrm{S} 17)$ & $\mathrm{V}(\mathrm{S} 15 \geq \mathrm{S} 17)$ & $\mathrm{V}(\mathrm{S} 16 \geq$ & $\mathrm{V}(\mathrm{S} 17 \geq$ & $\mathrm{V}(\mathrm{S} 18 \geq$ \\
$\mathrm{S} 17)=0.61$ & $=0.84$ & $=0.99$ & $\mathrm{~S} 17)=1.00$ & $\mathrm{~S} 16)=0.99$ & $\mathrm{~S} 16)=1.00$ \\
\hline $\mathrm{V}(\mathrm{S} 13 \geq$ & $\mathrm{V}(\mathrm{S} 14 \geq \mathrm{S} 18)$ & $\mathrm{V}(\mathrm{S} 15 \geq \mathrm{S} 18)$ & $\mathrm{V}(\mathrm{S} 16 \geq$ & $\mathrm{V}(\mathrm{S} 17 \geq$ & $\mathrm{V}(\mathrm{S} 18 \geq$ \\
$\mathrm{S} 18)=0.32$ & $=0.56$ & $=0.72$ & $\mathrm{~S} 18)=0.74$ & $\mathrm{~S} 18)=0.74$ & $\mathrm{~S} 17)=1.00$ \\
\hline $\min \left\{\mathrm{V}\left(\mathrm{S}_{13} \geq\right.\right.$ & $\min \left\{\mathrm{V}\left(\mathrm{S}_{14} \geq\right.\right.$ & $\min \left\{\mathrm{V}\left(\mathrm{S}_{15} \geq\right.\right.$ & $\min \left\{\mathrm{V}\left(\mathrm{S}_{16} \geq\right.\right.$ & $\min \left\{\mathrm{V}\left(\mathrm{S}_{17} \geq\right.\right.$ & $\min \left\{\mathrm{V}\left(\mathrm{S}_{18} \geq\right.\right.$ \\
$\left.\left.\mathrm{S}_{\mathrm{k}}\right)\right\}=0.32$ & $\left.\left.\mathrm{~S}_{\mathrm{k}}\right)\right\}=0.56$ & $\left.\left.\mathrm{~S}_{\mathrm{k}}\right)\right\}=0.72$ & $\left.\left.\mathrm{~S}_{\mathrm{k}}\right)\right\}=0.74$ & $\left.\left.\mathrm{~S}_{\mathrm{k}}\right)\right\}=0.74$ & $\left.\left.\mathrm{~S}_{\mathrm{k}}\right)\right\}=1$ \\
Weight $=$ & $\mathrm{Weight}=$ & $\mathrm{Weight}=$ & $\mathrm{Weight}=$ & $\mathrm{Weight}=$ & $\mathrm{Weight}=$ \\
0.0605 & 0.1060 & 0.1349 & 0.1393 & 0.1396 & 0.1884 \\
\hline
\end{tabular}

Table 7 Weight of each landfill site selection criteria/thematic layer calculated using FAHPSVM and FAHP-RF model

\begin{tabular}{|l|l|l|l|l|l|l|}
\hline $\begin{array}{l}\text { Selected decision criteria } \\
\text { thematic layer) }\end{array}$ & $\begin{array}{l}\text { Weig } \\
\text { ht } \\
\text { (SVM } \\
\text { (SVeight }\end{array}$ & $\begin{array}{l}\text { Final } \\
\text { (FAHP) }\end{array}$ & $\begin{array}{l}\text { Weight } \\
\text { (FAHP- } \\
\text { SVM) }\end{array}$ & $\begin{array}{l}\text { Weight } \\
\text { RF) }\end{array}$ & $\begin{array}{l}\text { Weig } \\
\text { ht } \\
\text { (FAH } \\
\text { P) }\end{array}$ & $\begin{array}{l}\text { Final weight } \\
\text { Final weight } \\
\text { (FAHP-RF) }\end{array}$ \\
\hline Land elevation & 0.000 & 0.000 & 0.000 & 0.002 & 0.000 & 0.000 \\
\hline Slope & 0.000 & 0.000 & 0.000 & 0.000 & 0.000 & 0.000 \\
\hline $\begin{array}{l}\text { Land surface } \\
\text { temperature }\end{array}$ & 0.002 & 0.000 & 0.000 & 0.056 & 0.000 & 0.000 \\
\hline Soil moisture index & 0.005 & 0.000 & 0.000 & 0.061 & 0.000 & 0.000 \\
\hline Land use and land cover & 0.074 & 0.053 & 0.048 & 0.047 & 0.053 & 0.043 \\
\hline $\begin{array}{l}\text { Normalized difference } \\
\text { built-up index }\end{array}$ & 0.083 & 0.076 & 0.078 & 0.095 & 0.076 & 0.125 \\
\hline $\begin{array}{l}\text { Normalized difference } \\
\text { vegetation index }\end{array}$ & 0.010 & 0.000 & 0.000 & 0.078 & 0.000 & 0.000 \\
\hline Urban concentration & 0.008 & 0.000 & 0.000 & 0.068 & 0.000 & 0.000 \\
\hline $\begin{array}{l}\text { Nearness to surface } \\
\text { waterbodies }\end{array}$ & 0.123 & 0.007 & 0.011 & 0.127 & 0.007 & 0.016 \\
\hline Nearness to drains & 0.077 & 0.012 & 0.012 & 0.029 & 0.012 & 0.006 \\
\hline Nearness to railway line & 0.081 & 0.039 & 0.039 & 0.029 & 0.039 & 0.020 \\
\hline $\begin{array}{l}\text { Nearness to national } \\
\text { highway }\end{array}$ & 0.071 & 0.043 & 0.037 & 0.064 & 0.043 & 0.047 \\
\hline $\begin{array}{l}\text { Nearness to state } \\
\text { highway }\end{array}$ & 0.057 & 0.061 & 0.042 & 0.078 & 0.061 & 0.081 \\
\hline $\begin{array}{l}\text { Nearness to residential } \\
\text { roads }\end{array}$ & 0.097 & 0.106 & 0.125 & 0.059 & 0.106 & 0.107 \\
\hline $\begin{array}{l}\text { Nearness to hospital and } \\
\text { clinic }\end{array}$ & 0.066 & 0.135 & 0.108 & 0.061 & 0.135 & 0.142 \\
\hline
\end{tabular}




\begin{tabular}{|l|l|l|l|l|l|l|}
\hline Nearness to park & 0.045 & 0.139 & 0.077 & 0.053 & 0.139 & 0.128 \\
\hline Distance from waste bins & 0.061 & 0.140 & 0.103 & 0.024 & 0.140 & 0.058 \\
\hline Land value & 0.139 & 0.188 & 0.320 & 0.070 & 0.188 & 0.228 \\
\hline$\sum$ (Normalized weight) & 1.000 & 1.000 & 1.000 & 1.000 & 1.000 & 1.000 \\
\hline
\end{tabular}

15 Table 8 Details regarding the selection of final sanitary landfill candidate sites

\begin{tabular}{|c|c|c|c|c|c|}
\hline Sites & Area (Sqft) & $\begin{array}{l}\text { Area } \\
\text { (ha) }\end{array}$ & Suitability & $\begin{array}{l}\text { Final } \\
\text { decision }\end{array}$ & $\begin{array}{l}\text { Causes of acceptation or } \\
\text { rejection }\end{array}$ \\
\hline Site-1 & 1018275.28 & 9.46 & Suitable & Accepted & $\begin{array}{l}\text { Located near the current open } \\
\text { dump site; absence of high } \\
\text { built-up areas; as per zonal } \\
\text { division, this site can cover } \\
\text { whole zone-I; and no public } \\
\text { objection have heard }\end{array}$ \\
\hline Site-2 & 1356739.18 & 12.60 & Permissible & Rejected & $\begin{array}{l}\text { Although this site is locate on } \\
\text { open space, periphery of the } \\
\text { main city and also absence of } \\
\text { high built-up areas; but as per } \\
\text { zonal division, this site } \\
\text { located in one corner of zone- } \\
\text { II and transport cost will be } \\
\text { very high to cover whole } \\
\text { zone-II }\end{array}$ \\
\hline Site-3 & 879330.17 & 8.17 & Permissible & Rejected & $\begin{array}{l}\text { This site is close to railway } \\
\text { station, so should not consider } \\
\text { as suitable site }\end{array}$ \\
\hline Site-4 & 2101424.22 & 19.52 & Not suitable & Rejected & $\begin{array}{l}\text { This site is beside the } \\
\text { University (AMU) campus } \\
\text { and civil line area, which } \\
\text { would not be a suitable site }\end{array}$ \\
\hline Site-5 & 3232604.07 & 30.03 & Suitable & Accepted & $\begin{array}{l}\text { Located at a suitable site; } \\
\text { periphery of the main city; } \\
\text { absence of residential areas; } \\
\text { as per zonal division, this site } \\
\text { can cover the zone-II, and no } \\
\text { public objection and it has } \\
\text { largest area in comparison to } \\
\text { all candidate sites }\end{array}$ \\
\hline Site-6 & 722431.97 & 6.71 & Not available place & Rejected & $\begin{array}{l}\text { Very little available space is } \\
\text { there, surrounded by many } \\
\text { residential colonies. Public }\end{array}$ \\
\hline
\end{tabular}




\begin{tabular}{|l|l|l|l|l|l|}
\hline Site-7 & & & & & Suitable \\
& Accepted & $\begin{array}{l}\text { Located at a suitable site, } \\
\text { south-eastern margin from the } \\
\text { main city, far away from high } \\
\text { residential areas; this site can } \\
\text { cover the zone-III, and also } \\
\text { no public objection on sitting } \\
\text { new landfill }\end{array}$ \\
\hline
\end{tabular}

\section{List of figures}
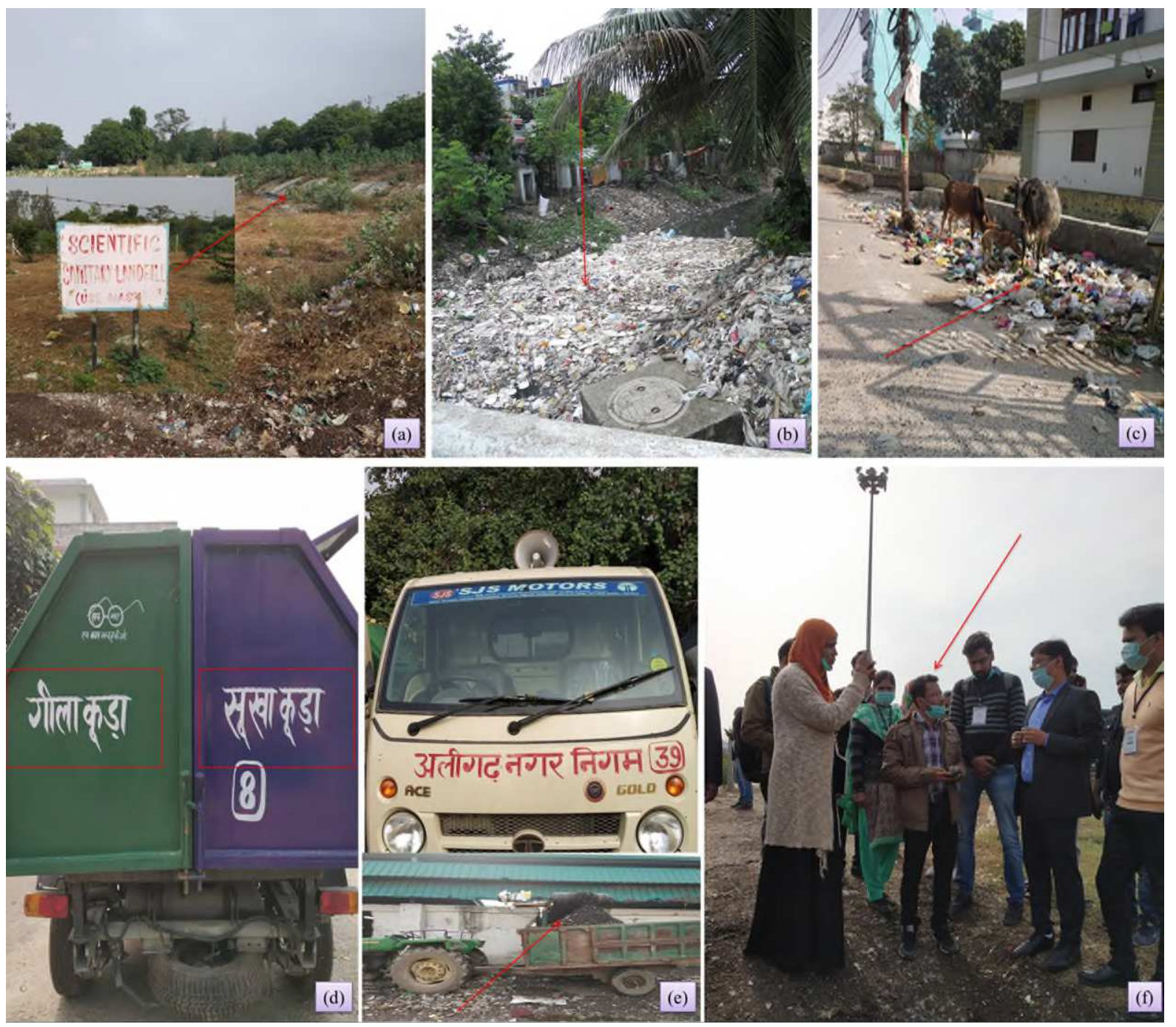

Fig. 1 Some photographs showing issues related to solid waste management in Aligarh city

(a) site selected for sanitary landfill, but not functioned; (b) solid waste disposed in drains; (c) 
22 collecting vehicles in the city; (f) the corresponding author, discussing with municipal

23 authorities regarding the waste management in the city
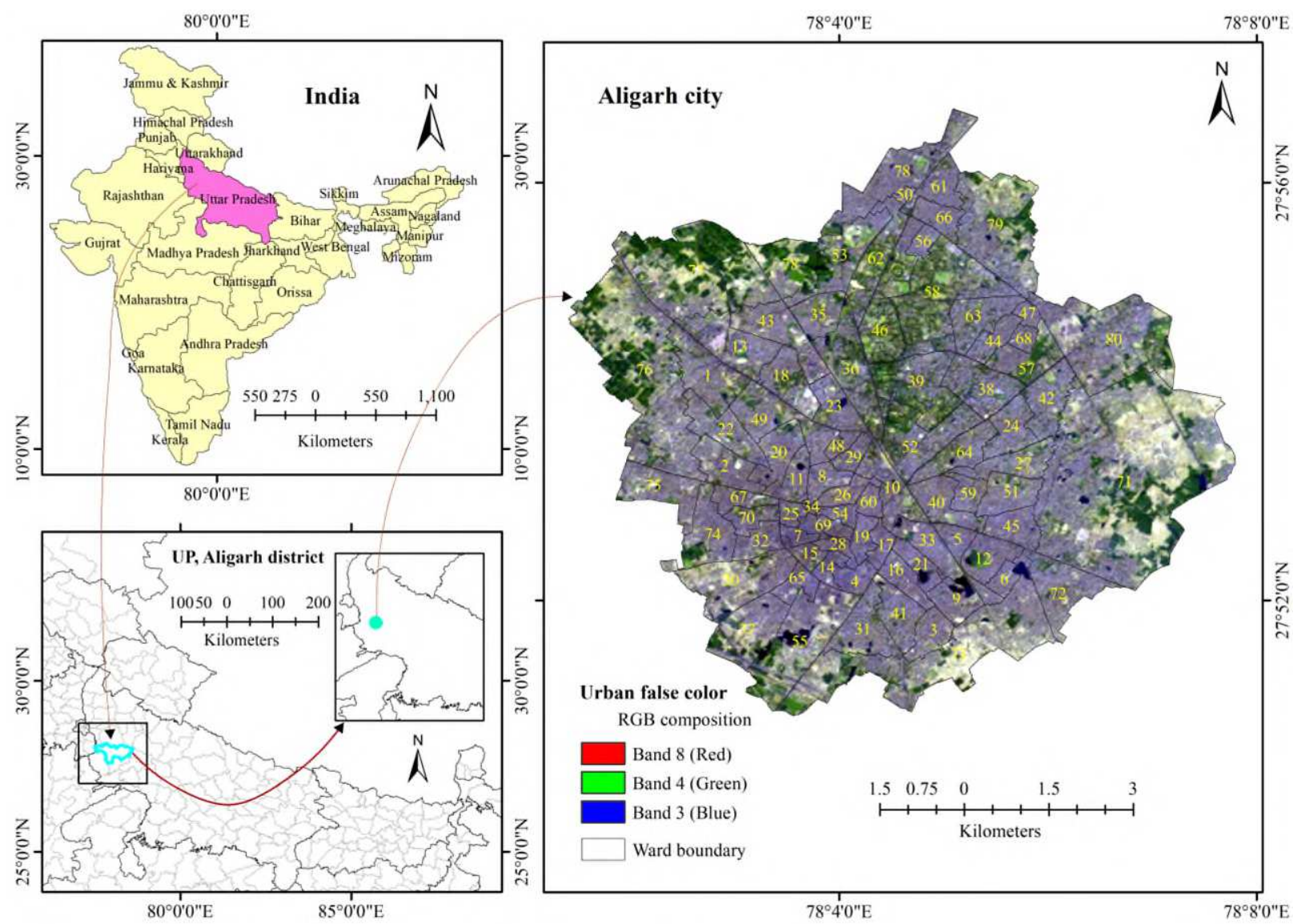

25 Fig. 2 location map of the study area with administrative wards (India, Uttar Pradesh, Aligarh district, Aligarh city) 


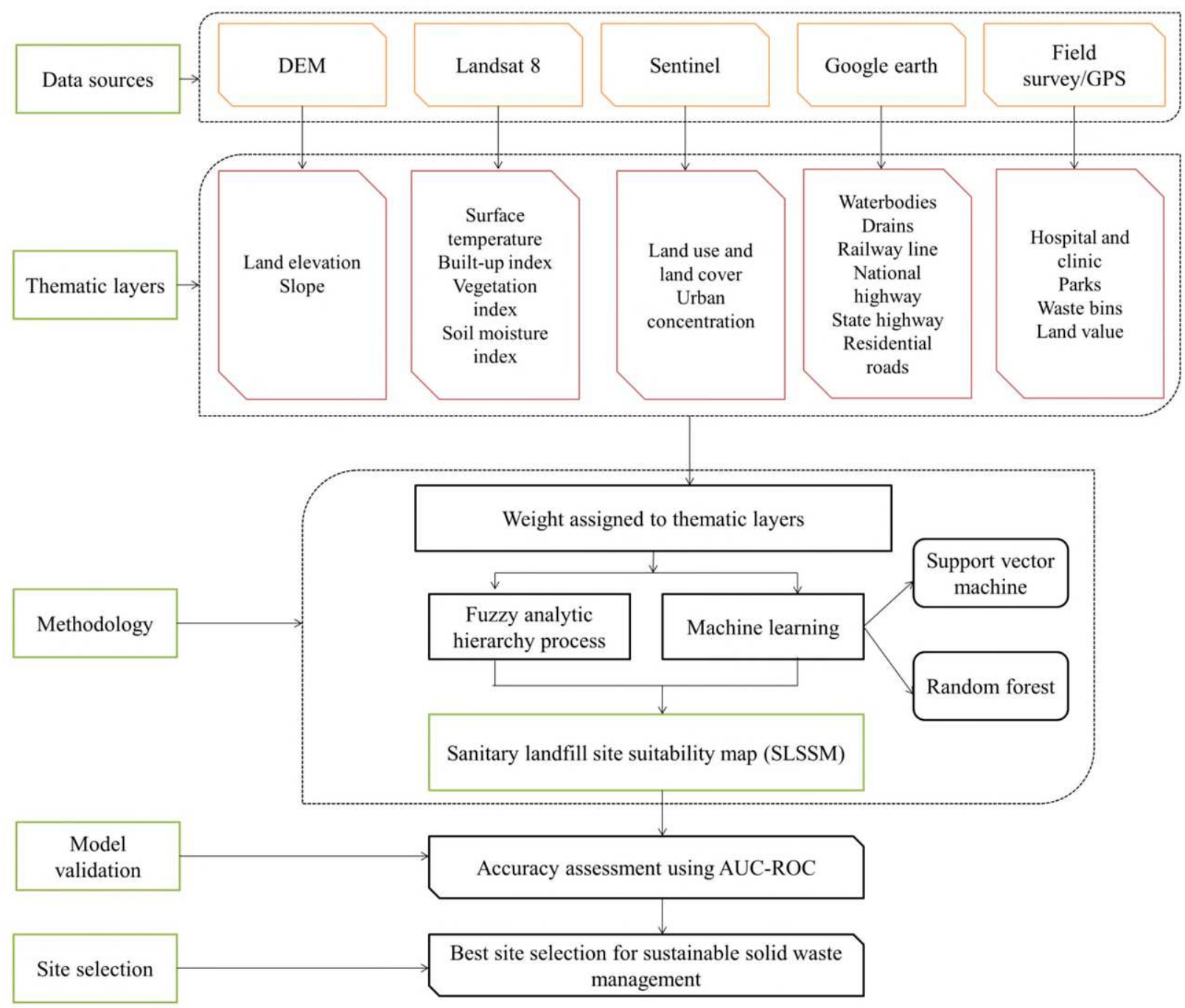

27

Fig. 3 Flow chart showing materials and methods used for sanitary landfill site selection 

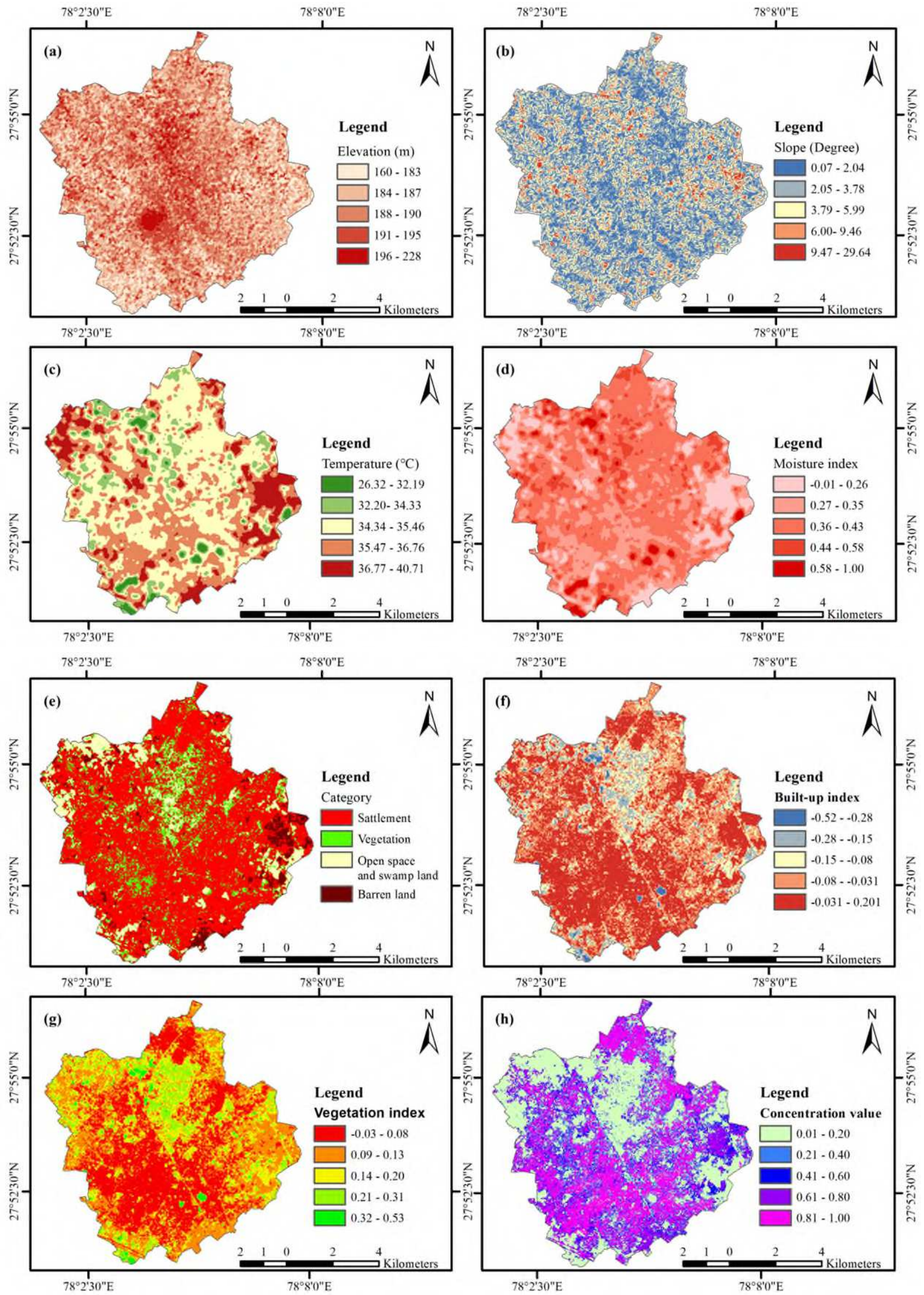

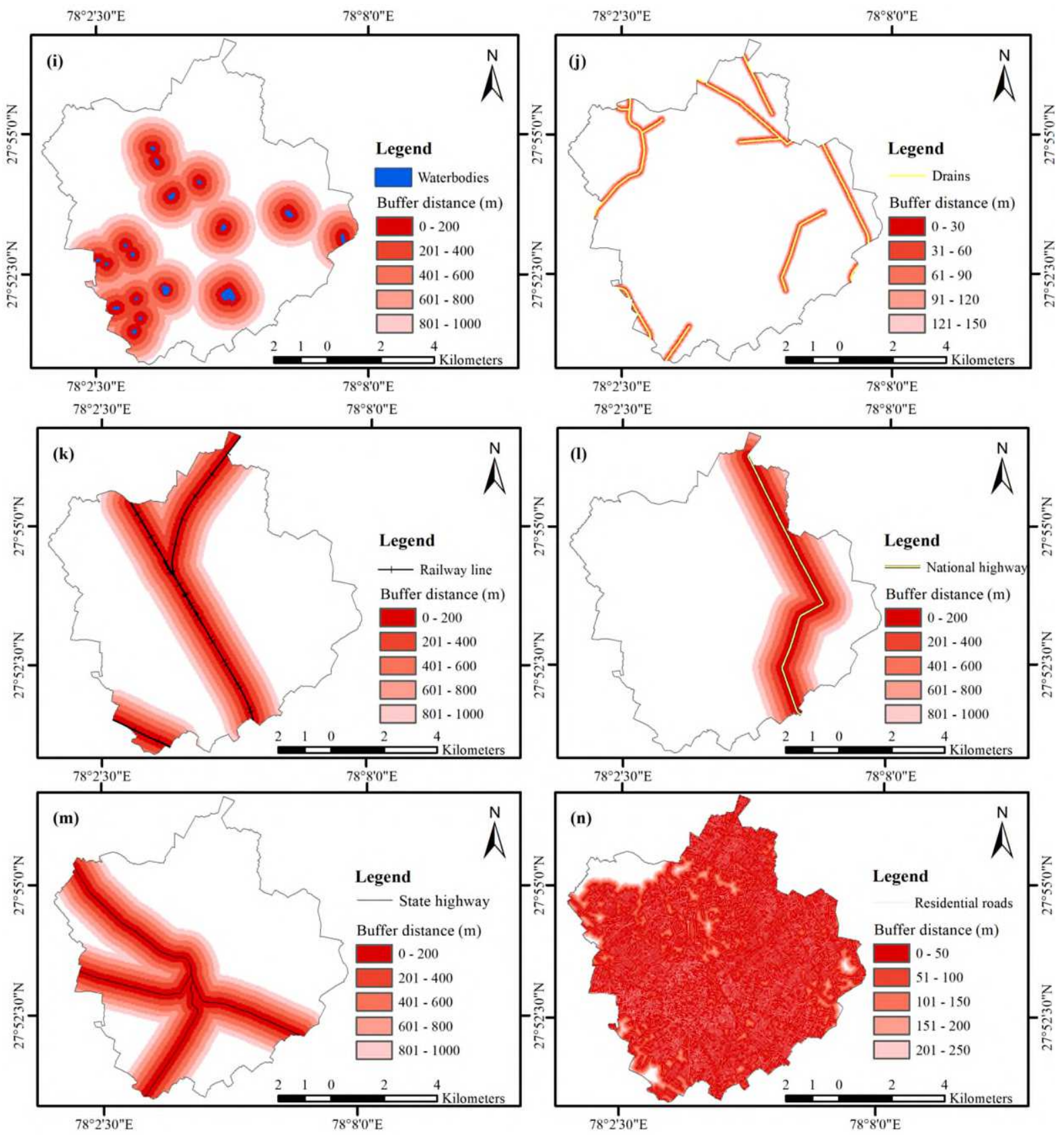

32 

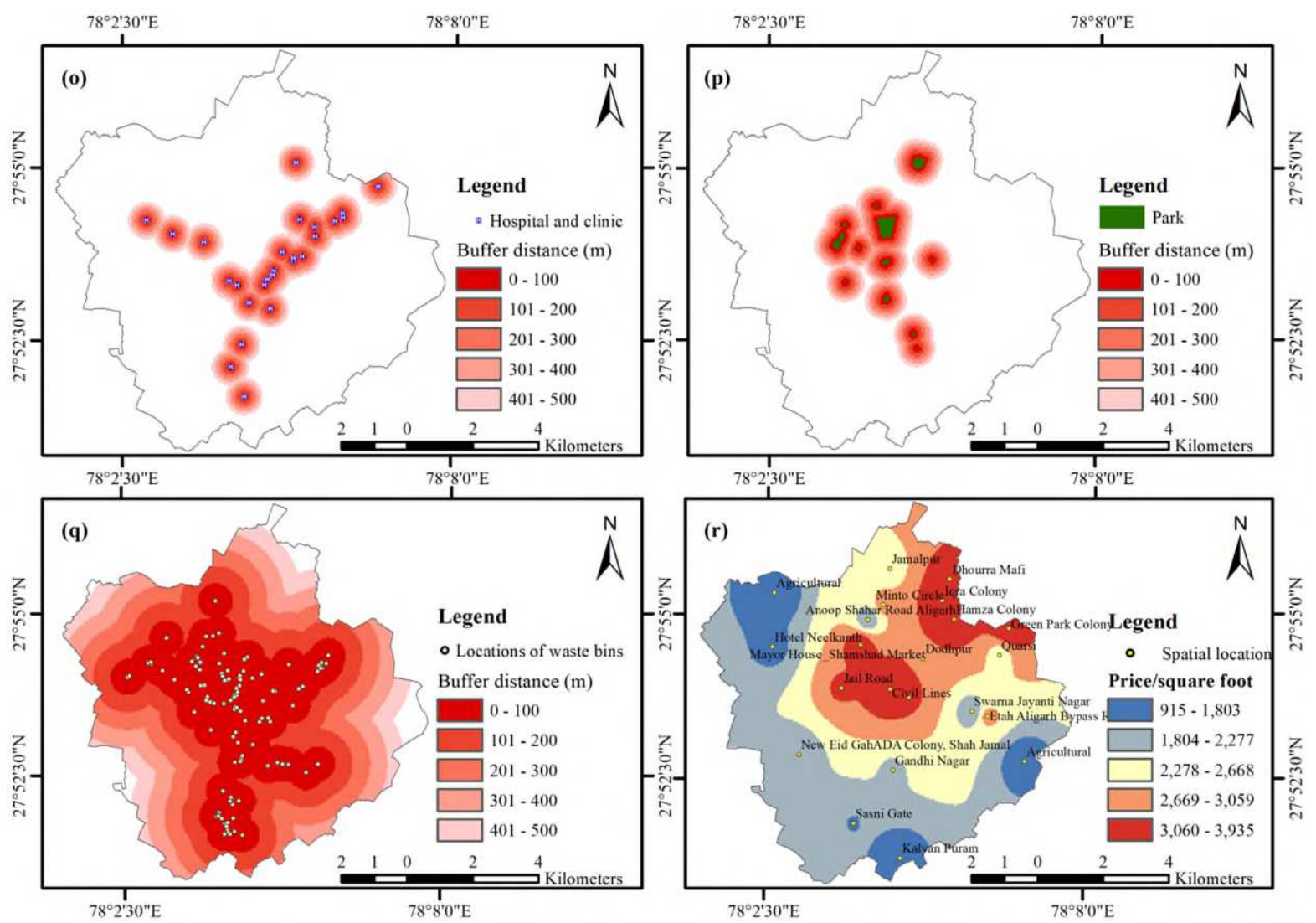

Fig. 4 Thematic layers for sanitary landfill site selection (a) land elevation, (b) slope, (c) land surface temperature, (d) soil moisture index, (e) land use and land cover, (f) normalized difference built-up index (NDBI), (g) normalized difference vegetation index (NDVI), (h)

37 urban concentration, (i) nearness to surface waterbodies, (j) nearness to drains, (k) nearness to railway line, (1) nearness to national highway, (m) nearness to state highway, (n) nearness to residential roads, (o) nearness to hospital and clinic, (p) nearness to park, (q) distance from waste bins, and (r) land value 

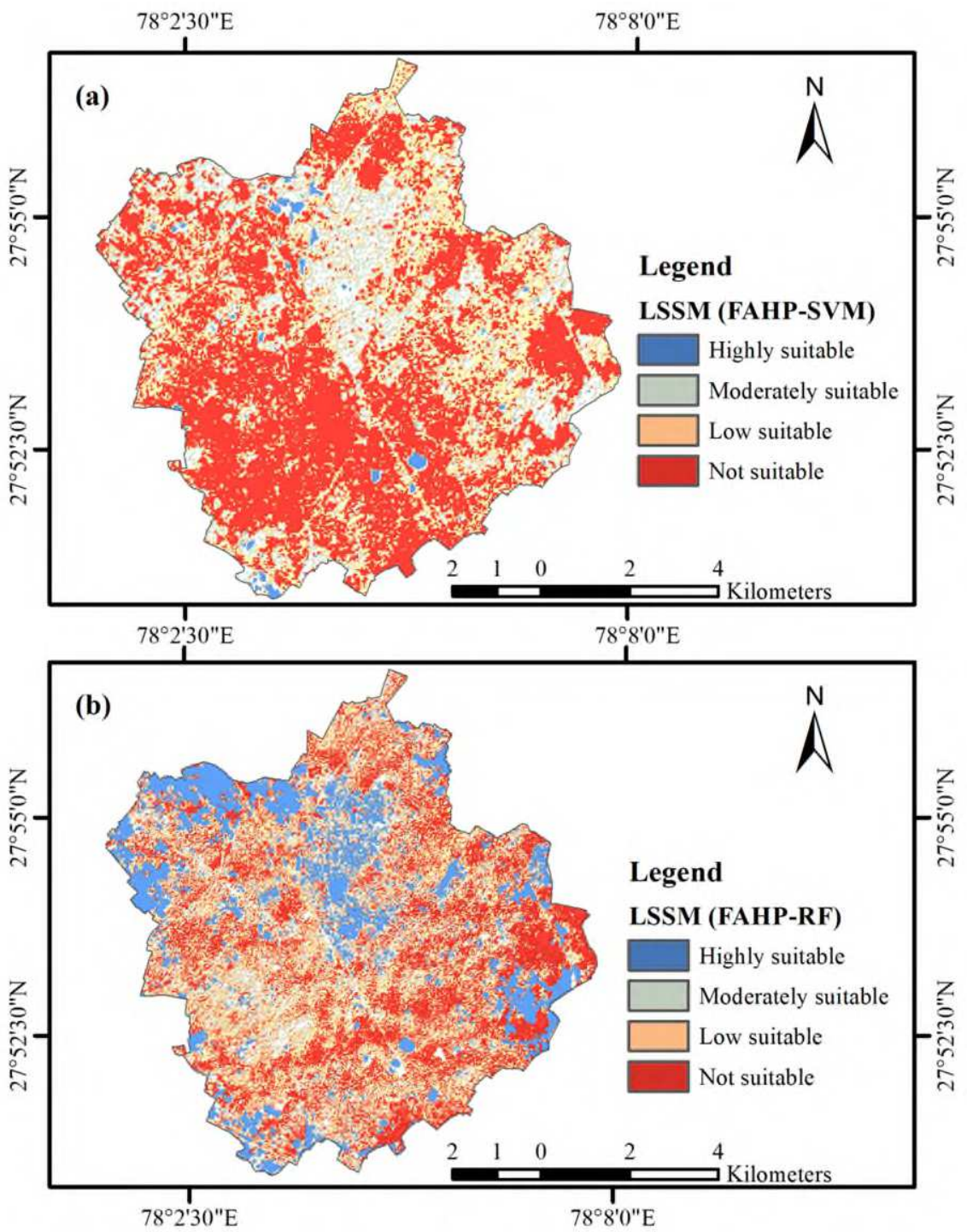

42 Fig. 5 Landfill site suitability map (LSSM), (a) FAHP-SVM (b) FAHP-RF 

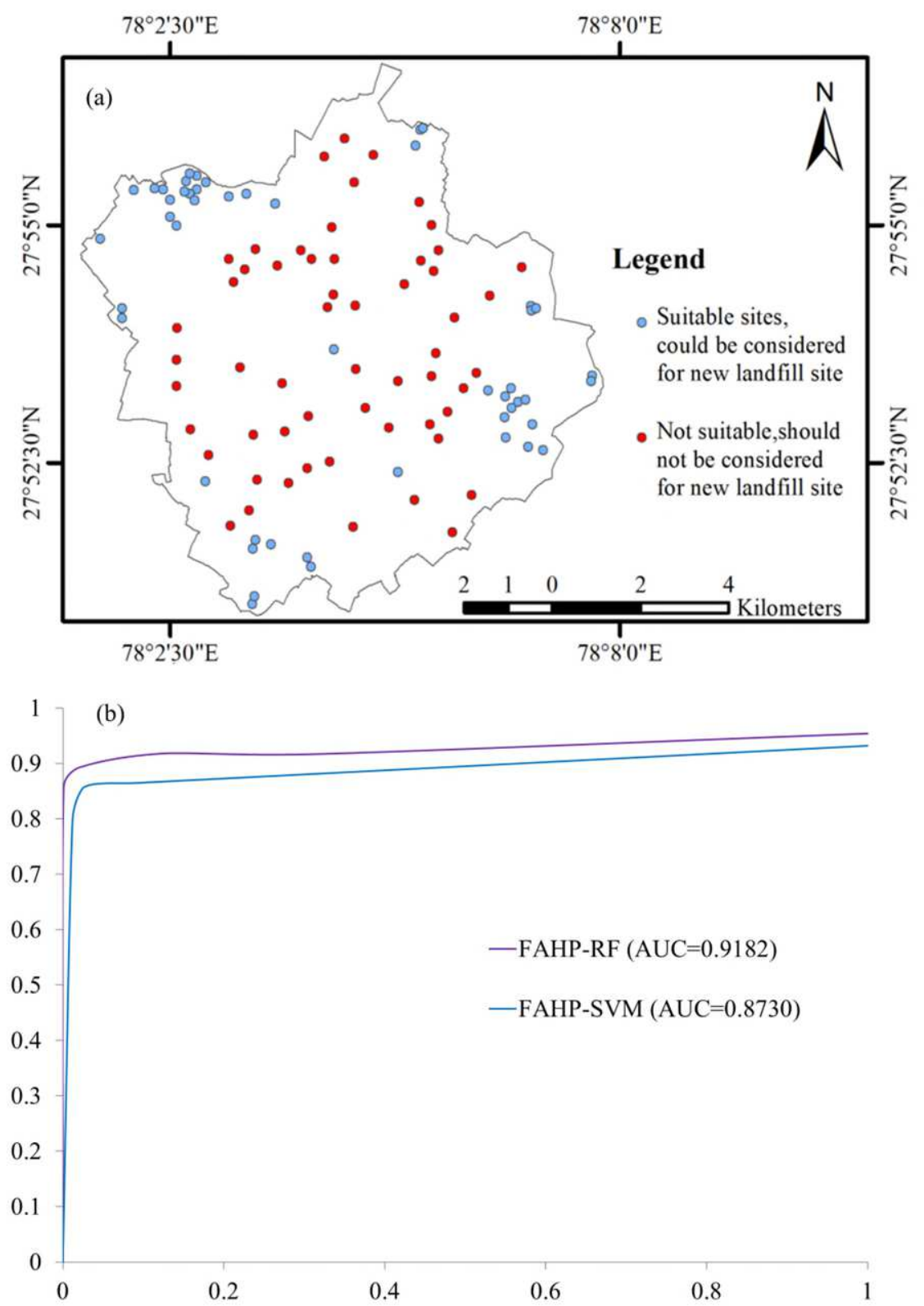

$44 \quad$ Fig. 6 (a) GPS location defining suitable and unsuitable landfill sites (b) accuracy assessment of the applied models FAHP-SVM FAHP-RF 


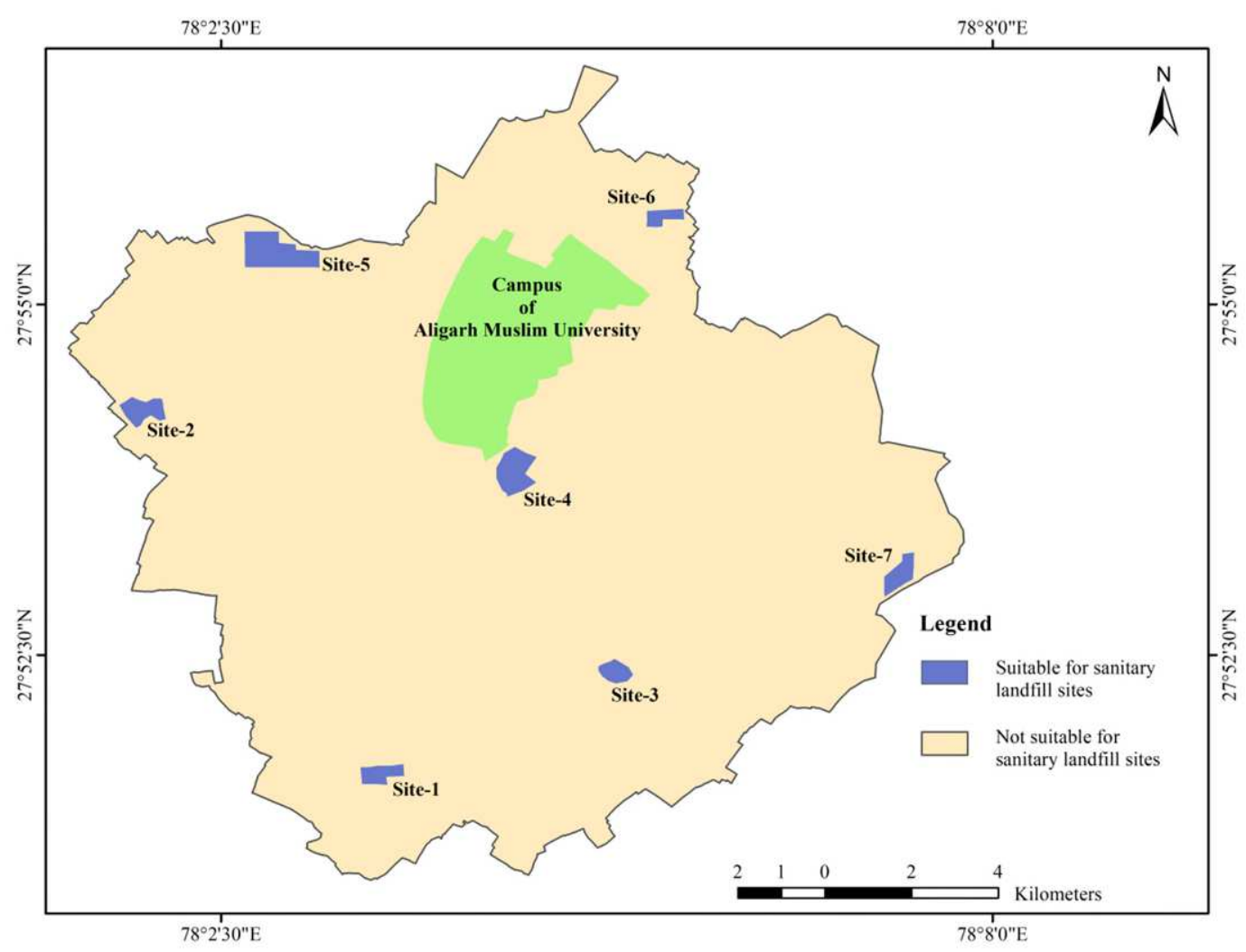

$47 \quad$ Fig. 7 Suitable candidate sites for sanitary landfill sites in Aligarh city

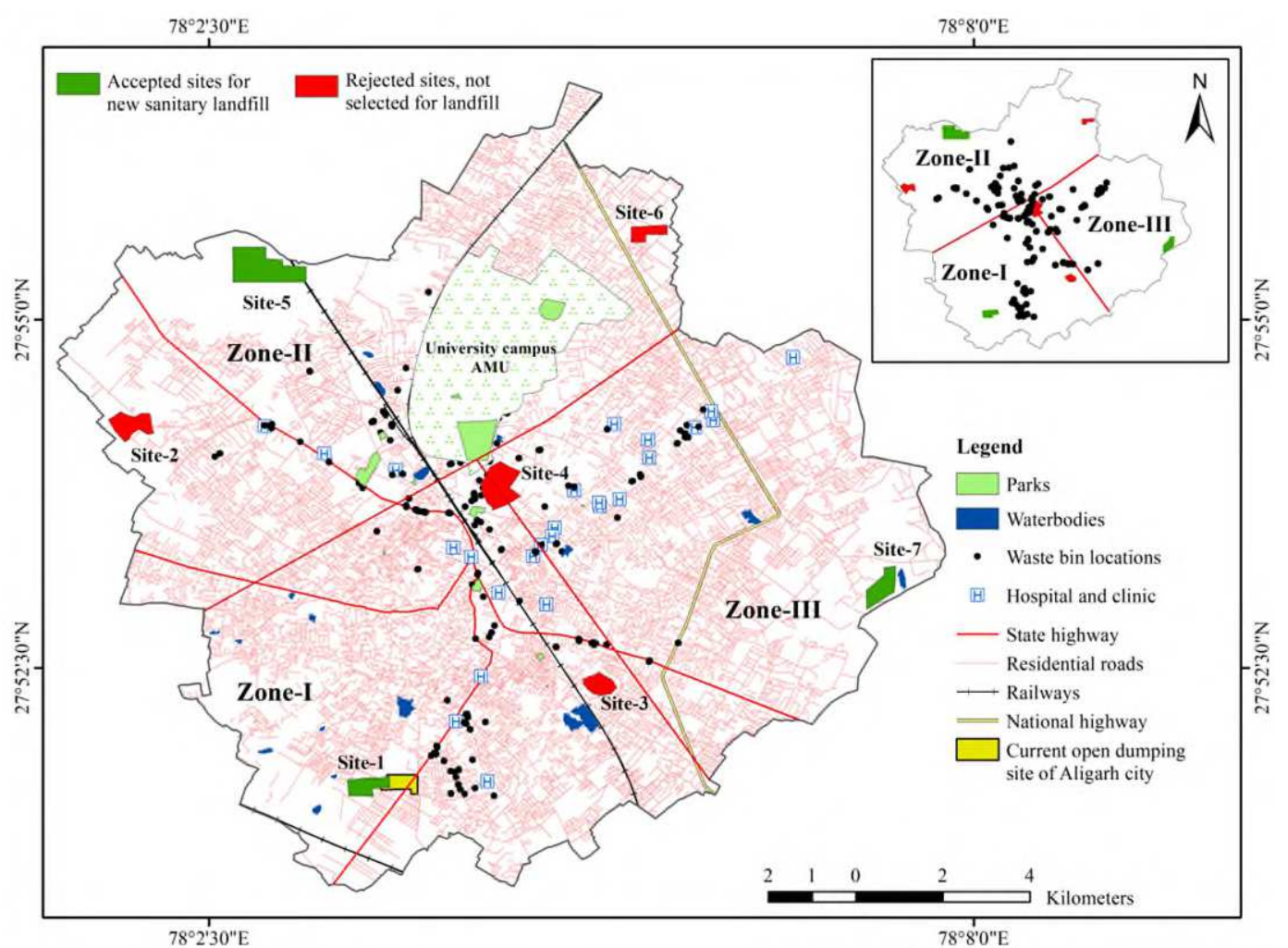

Fig. 8 Zonal division of the study area and final sanitary landfill map showing accepted and rejected sites 